$$
\text { DOE/CE/283/2-TB-VOLI }
$$

\title{
Program Evaluation: Weatherization Residential Assistance Partnership (WRAP) Program
}

\section{Volume I \\ Final Report}

Prepared for

Northeast Utilities

WRAP Task Force

December 1991

\section{ICF RESOURCES ${ }^{\text {SM }}$}

\section{INCORPORATED}

9300 Lee Highway

Fairfax, Va. 22031-1207 
To the Reader:

This report and companion documents represent an extensive evaluation of the Weatherization Residential Assistance Partnership (WRAP) Program. Many individuals contributed to both the program and evaluation research. Some major contributors to the research include Jan Bernard, Tom Dunklee, and Michelle Gallichio and the WRAP steering committee.

The research for this project has indicated the the WRAP program has been very successful at supplying needed weatherization and other conservation measures, educating the low-income program participants, contributing to many of the social and community-based goals and objectives defined by the connecticut collaborative process, and saving considerable amounts of electricity, gas, oil, propane and other fuels. The WRAP program also meets urban and rural customer needs equitably. However, there were some issues raised the this research that should be addressed.

One significant issue indicated by the research was that there are substantial numbers of low-income household that require significant improvements for lowering of energy bills. Many dwellings were found that needed not only weatherization, but also furnace or boiler replacements because of inoperable or inefficient equipment. During the 1990 program year, over 150 such homes were referred to the WRAP program. Many were eligible for services from the U.S. Department of Energy funded Weatherization Assistance Program (WAP). Some services were provided in partnership with public funds, others were totally utility funded. It became evident that the program cannot afford to subsidize these services alone. Beginning in 1991, DOE has provided $\$ 50,000$ as "leveraging" funds to match the utility contributions for furnace and boiler replacement. Additional funds will be required in future program years.

The program was designed to be fuel-blind. That is, weatherization and dwelling improvement would take place within the program regardless of primary heating and water heating fuel source. As a result of this design, success has been achieved in the saving of home heating fuel for many participants. In some units, the state, using public and petroleum settlement funds, is the prime funder. In other units, the electric company is subsidizing most of these measures, with some contribution from the gas companies. Given the program success, it seems reasonable the the fuel suppliers should bear the costs of these improvements. Discussions are being held towards the expansion of the gas company contributions. Initial legislation has also been passed to obtain oil company participation. Northeast Utilities feels that revision of this legislation is needed to strengthen this requirement.

Northeast Utilities is proud of the contributions that the WRAP program has made within the low-income customer base. We feel that future program years will enhance and expand on these contributions.

Sara S. Ellison

Director - Community Relations

Northeast Utilities

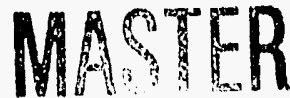




\title{
Program Evaluation: Weatherization Residential Assistance Partnership (WRAP) Program
}

\author{
Volume I \\ Final Report
}

Prepared for
Northeast Utilities
WRAP Task Force
Prepared by
ICF Resources Incorporated

December 1991

DISCLAIMER

This report was prepared as an account of work sponsored by an agency of the United States Government. Neither the United States Government nor any agency thereof, nor iny of their employees, makes any warranty, express or implied, or assumes any legal liability or responsibility for the accuracy, completeness, or usefulness of any information, apparatus, product, or process disclosed, or represents that its use would not infringe privately owned rights. Reference herein to any specific commercial product, process, or service by trade näinic, irademark, manufgcturer, oi útilerwise does not necessarily constitute or imply its endorsement, recommendation, or favoring by the United States Government or any agency thereof. The views and opinions of authors expressed herein do not necessarily state or reflict those of the United States Government or any agency thereof. 
this evaluation report is dedicated to the memory of

Charles R. "Tom" Dunklee 
The complete program evaluation comprises five documents:

Principal evaluation document:

Program Evaluation: Weatherization Residential Assistance Partnership (WRAP) Program, ICF Resources Incorporated, December 1991.

Volume I: Final Report

Volume II: Appendices A, B, and C

Volume III: Appendices D, E, F, and G

Companion documents:

WRAP Program Evaluation, Steven Ferrey \& Associates, 1990.

Process Evaluation, Weatherization Residential Assistance Partnership (WRAP Program), Technical Development Corporation, October 1990.

Key conclusions and documentation from both companion documents have been incorporated into the principal report.

Key Investigators:

ICF Resources Incorporated 9300 Lee Highway

Fairfax, Virginia 22031

(703) 934-3000

Steven Ferrey \& Associates

Technical Development Corporation
Bonnie B. Jacobson, Vice President

Barbara Lundien, Analyst

Jeffrey Kaufman, Analyst

Adam Kreczko, Associate

Steven Ferrey

Stephen Morgan

ICF Resources would like to recognize the following organizations and individuals for their invaluable assistance to this evaluation:

Northeast Utilities

CHIF/WRAP Unit
Sara S. Ellison

Alice Kelley

Pearl Bouchard

Marlene Martino

Steven Waite

Jan Barnard

Dean Sandstrom 


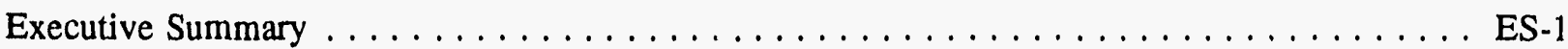

Development, Design, and Process Evaluations $\ldots \ldots \ldots \ldots \ldots \ldots$ ES-2

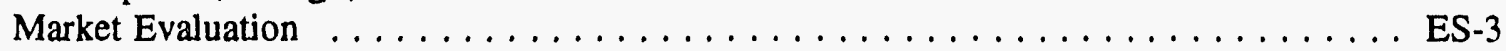

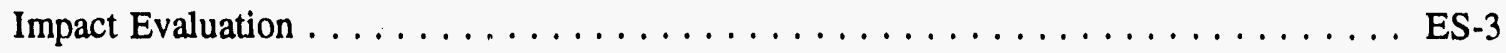

1. Introduction to the WRAP Program $\ldots \ldots \ldots \ldots \ldots \ldots \ldots \ldots \ldots \ldots \ldots \ldots \ldots \ldots$

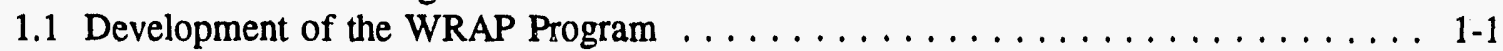

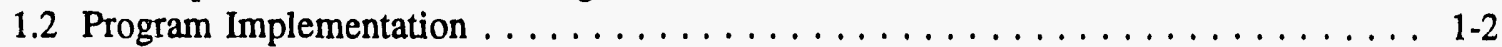

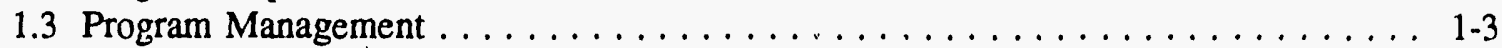

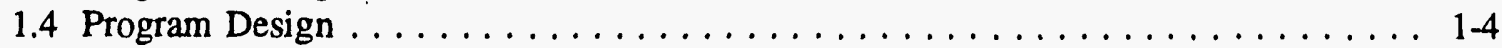

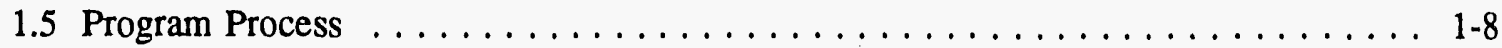

2. Development, Design, and Process Evaluation $\ldots \ldots \ldots \ldots \ldots \ldots \ldots \ldots \ldots \ldots \ldots$

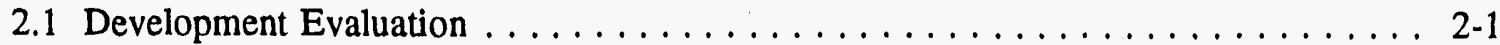

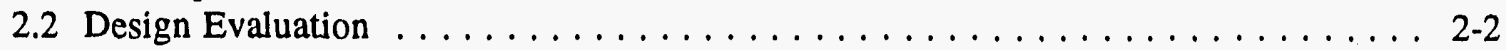

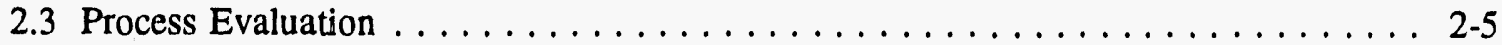

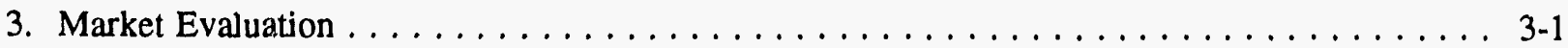

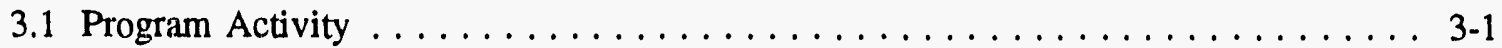

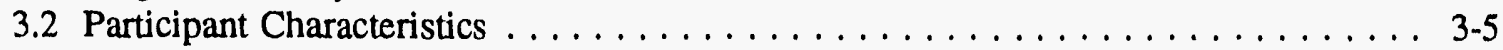

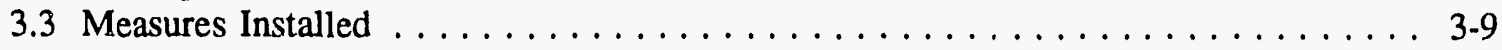

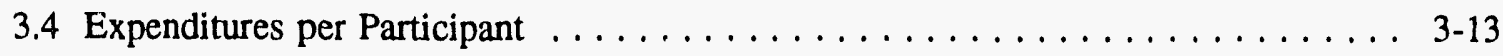

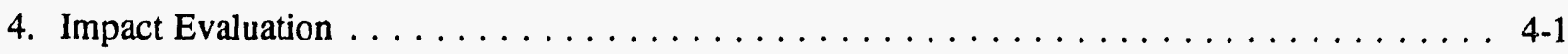

4.1 Description of Data ......................... 4-1

4.2 First Year Electricity Savings Based on Billing Data . . . . . . . . . . . 4-2

4.3 First Year Electricity Savings Based on Engineering Estimates . . . . . . . . . 4 4-7

4.4 Lifetime Electricity Savings Based on Engineering Estimates . . . . . . . . . . . 4-11

4.5 Total Energy Savings Based on Engineering Estimates . . . . . . . . . . . . . 4-15

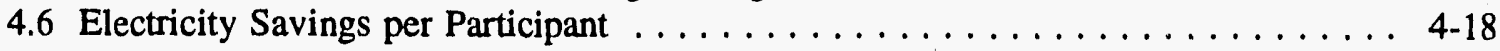

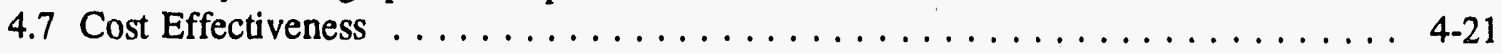

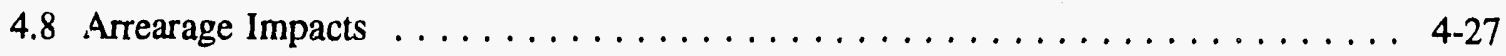




\section{List of Tables}

Table ES-1

Table ES-2

Table ES-3

Table 1-1

Table 1-2

Table 2-1

Table 2-2

Table 2-3

Table 2-4

Table 2-5

Table 3-1

Table 3-2

Table 3-3

Table 3-4

Table 3-5

Table 3-6

Table 3-7

Table 4-1

Table 4-2

Table 4-3

Table 4-4

Table 4-5

Table 4-6

Table 4-7

Table 4-8
WRAP Design Evaluation Summary

ES-3

Summary of First Year Electricity Savings per Participant,

Engineering Estimates vs. Actual $\ldots \ldots \ldots \ldots \ldots \ldots \ldots \ldots \ldots$ ES-5

Lifetime Energy Savings per Participant $\ldots \ldots \ldots \ldots \ldots \ldots \ldots \ldots$ ES-6

Measures Available for Weatherization Residential

Assistance Partnership (WRAP) Program . . . . . . . . . . . . . . 1-6

WRAP Plan Descriptions . . . . . . . . . . . . . . . . . . . . . 1-9

WRAP Design Evaluation Summary $\ldots \ldots \ldots \ldots \ldots \ldots \ldots \ldots \ldots \ldots . \ldots \ldots$

WRAP Process Evaluation Summary . . . . . . . . . . . . . . . . . 2-6

Number of Participants as a Percentage of Year-End Goal . . . . . . . . . . 2 2-8

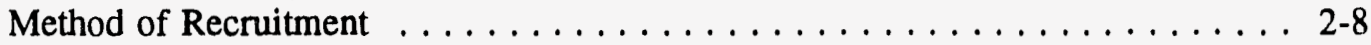

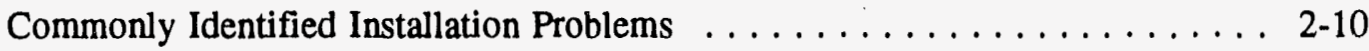

1989 Participant Demographics . . . . . . . . . . . . . . . . . . . . 3-5

1990 Participant Demographics . . . . . . . . . . . . . . . . . . . . 3-6

Primary Space Heating Fuels of 1989 Participants . . . . . . . . . . . . . . . . 3-7

Primary Space Heating Fuels of 1990 Participants . . . . . . . . . . . . . . . 3 3-8

Measures Received Under WRAP . . . . . . . . . . . . . . . . 3-12

WRAP Expenditures per 1989 Participant $\ldots \ldots \ldots \ldots \ldots \ldots \ldots \ldots \ldots$ 3-14

WRAP Expenditures per 1990 Participant $\ldots \ldots \ldots \ldots \ldots \ldots \ldots \ldots \ldots$ 3-15

First Year Electricity Savings Based on Billing Data, 1989 Participants

(by urban/rural and owner/renter status) $\ldots \ldots \ldots \ldots \ldots \ldots \ldots . \ldots .4$

First Year Electricity Savings Based on Billing Data, 1989 Participants

(by primary space heating fuel) $\ldots \ldots \ldots \ldots \ldots \ldots \ldots \ldots \ldots$. . . . . .

First Year Electricity Savings Based on Billing Data, 1990 Participants

(by urban/rural and owner/renter status) $\ldots \ldots \ldots \ldots \ldots \ldots \ldots \ldots$ 4-5

First Year Electricity Savings Based on Billing Data, 1990 Participants

(by primary space heating fuel) $\ldots \ldots \ldots \ldots \ldots \ldots \ldots \ldots \ldots$

First Year Electricity Savings Based on Engineering Estimates, 1989

Participants (by urban/rural and owner/renter status) $\ldots \ldots \ldots \ldots$. . . 4-7

First Year Electricity Savings Based on Engineering Estimates, 1989

Participants (by primary space heating fuel) $\ldots \ldots \ldots \ldots \ldots \ldots \ldots$ 4.8

First Year Electricity Savings Based on Engineering Estimates, 1990

Participants (by urban/rural and owner/renter status) . . . . . . . . . . . 4-9

First Year Electricity Savings Based on Engineering Estimates, 1900

Participants (by primary space heating fuel)

4-10 


\section{List of Tables (continued)}

Table 4-9 Lifetime Electricity Savings Based on Engineering Estimates, 1989

Participants (by urban/rural and owner/renter status) $\ldots \ldots \ldots \ldots \ldots$. . . . .

Table 4-10 Lifetime Electricity Savings Based on Engineering Estimates, 1989

Participants (by primary space heating fuel) $\ldots \ldots \ldots \ldots \ldots \ldots$ 4-12

Table 4-11 Lifetime Electricity Savings Based on Engineering Estimates, 1990

Participants (by urban/rural and owner/renter status) $\ldots \ldots \ldots \ldots$. . . . 13

Table 4-12 Lifetime Electricity Savings Based on Engineering Estimates, 1990

Participants (by primary space heating fuel) $\ldots \ldots \ldots \ldots \ldots$. . . . .

Table 4-13 First Year Fuel Savings Based on Engineering Estimates . . . . . . . . . . . 4-15

Table 4-14 Lifetime Fuel Savings Based on Engineering Estimates . . . . . . . . . . 4-16

Table 4-15 First Year Electricity Savings per Participant Based on Billing Data (kWh) . . . 4-18

Table 4-16 First Year Electricity Savings per Participant Based on Billing Data (percent) . . 4-19

Table 4-17 Dollars Spent by WRAP per Lifetime MMBtu Saved . . . . . . . . . . 4-21

Table 4-18 Dollars Spent by NU per kWh Electricity Saved . . . . . . . . . . . . . 4-22

Table 4-19 Dollars Spent by Gas Company per Lifetime ccf Gas Saved . . . . . . . . . . 4-23

Table 4-20 Dollars Spent by NU per Lifetime Gallon Oil Saved . . . . . . . . . . . . . . 4 4-24

Table 4-21 Dollars Saved by Participant per Dollar Spent by WRAP . . . . . . . . . . . 4-21 


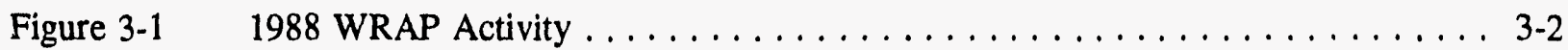

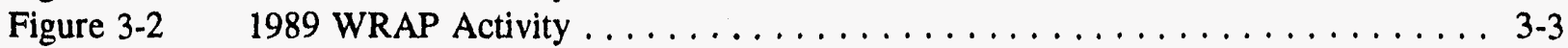

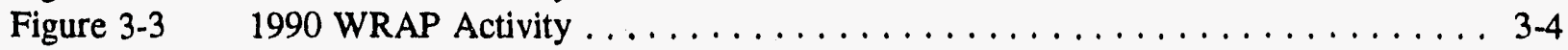

Figure 3-4 Measures Received by 1989 WRAP Participants . . . . . . . . . . . . . 3-10

Figure 3-5 Measures Received by 1990 WRAP Participants . . . . . . . . . . . . . 3-11

Figure 4-1 Total Energy Savings Based on Engineering Estimates $\ldots \ldots \ldots \ldots \ldots \ldots$ 4-17 


\section{Executive Summary}

The Connecticut low income weatherization program was developed in response to a 1987 rate docket order from the Connecticut Department of Public Utility Control (DPUC) to Connecticut Light \& Power Co., an operating subsidiary of Northeast Utilities (NU). (Throughout this report, NU is referred to as the operator of the program.) This program, known as the Weatherization Residential Assistance Partnership, or WRAP, was configured utilizing input from a collaborative group of interested parties to the docket. It was agreed that this program would be put forth by the electric utility, but would not ignore oil and gas savings (thus, it was to be "fuel-blind"). The allocated cost of conservation services for each fuel source, however, should be cost effective. It was to be offered to those utility customers at or below 200 percent of the federal poverty levels, and provide a wide array of energy saving measures directed toward heating, water heating and lighting. It was felt by the collaborative group that this program would raise the level of expenditures per participant for weatherization services provided by the state, and by linking to and revising the auditing process for weatherization, would lower the audit unit cost.

The program was initiated through the joint cooperation of Northeast Utilities (NU) and Yankee Gas, the operating subsidiary of Yankee Energy Systerns (YES). The Connecticut State Office of Policy and Management/Energy Division, the Office of Consuxner Counsel, the Department of Public Utilities Control and its Prosecutorial Unit, and the Department of Human Resources also joined the effort for planning and monitoring as did the Connecticut Association for Community Action and the Conservation Law Foundation. Funding was supplemented by Connecticut Natural Gas Corporation later in the program life.

The program was designed to incorporate five participation levels, referred to as program plans E1 through E5. The plans roughly correspond to increasing conservation service needs within the dwellings and the associated increased expenditure levels per dwelling. These program plans ranged from the offering of low-cost heating, water heating and infiltration measures, increased insulation levels, carpentry and plumbing services, to furnace or burner replacement. The program was configured to allow for very comprehensive weatherization and heating system servicing.

The program officially began late in 1988, but 1989 is considered an initial implementation year as well. During these years, the program was designed and modified, contracts were established with local Community Action Agencies (CAAs) for auditing/needs assessment and measure installation, and local utility representatives were introduced to the program concepts and requirements. Initially, there was "trial and error" regarding participant solicitation, data collection and measure installation. By 1990, the program had matured, and this is reflected in the program statistics.

Also during the initial stages of the program offering, a comprehensive evaluation framework was designed to allow for a total overview of program activity and results. This set of evaluation documents encompasses the results of that effort. The evaluation included a market and demographic assessment of the participants, a process assessment (including quality control), an impact review (in both dollars spent and energy saved), and cost-eifectiveness testing. A summary of all evaluations is contained within this document; the companion documents (WRAP Program Evaluation, Steven Ferry, 1990, and Process Evaluation, Weatherization Residential Assistance Partnership (WRAP Program), Technical Development Corporation, 1990) give grearer detail on the development, design, and process evaluations. These evaluations were initiated under the direction of the NU Community Relations and Conservation and Load 
Management Departments, Yankee Energy Systems Conservation and Load Management Department, the WRAP Task Force, and the U.S. Department of Energy.

\section{Development, Design, and Process Evaluations}

Overall, the findings of the development, design, and process evaluations were very positive. Northeast Utilities' DSM option screening methodology, used in program development, was appropriate and effective. The collaborative approach also produced positive results in terms of its input to program design. This concept for low-income weatherization is also supported by literature on the subject.

Several aspects of WRAP's program design are particularly successful. While households in the 150 to 200 percent poverty level are not eligible for most assistance programs, they often have the same housing and energy needs as households in lower income brackets. WRAP's recruitment of these households represents a large, formerly untapped market associated with potential savings similar to those of lower income households. The wide range of measures available under WRAP allows for maximum tailoring of services to the needs of the household, as well as more comprehensive treatment of energy needs; both characteristics contribute to higher program cost efficiency. The flexible structure of the $p$ ogram has allowed for changes in response to lessons learned through program experience. The WRAP program is also compatible with assisted housing.

In addition to the quantifiable utility goals of energy savings and arrearage reduction, WRAP was designed to meet other goals of the customers and the low-income community. The results of the WRAP participant survey indicate that the program successfully achieved several of its qualitative objectives. Sixty five percent of survey participants reported that they felt more comfortable in their homes since the weatherization. Over ninety five percent rated Northeast Utilities' service as good or very good, and almost half said that their opinion of their local utility company was better than it had been prior to the installation (forty six percent said that their opinion was unchanged).

Other aspects of WRAP's design were less successful at the time of the initial program evaluation. Early recipients of lighting measures expressed dissatisfaction with the results due to lowered lighting levels; the program has since responded by installing highly efficient fixtures that provide lighting levels equivalent to those of the less efficient fixtures replaced. The original WRAP program design did not

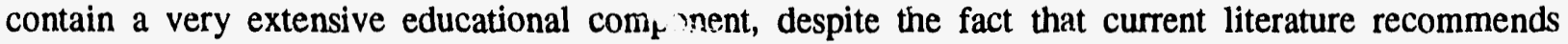
education as an effective savings-boosting pari of a weatherization program. In response to this finding, the educational component was increased substantially, in part through the adoption of a "portable audit" which includes a strong educational approach.

Another less successful aspect of program design is the funding arrangement. While gas company involvement has increased since the program's inception, Northeast Utilities currently funds all oil and propane saving measures, and most gas saving measures, in addition to electricity saving measures. This is despite the fact that only about one out of every ten participants have primary electric space heating, and lifetime electricity savings from the period January 1991 through November 1991 accounted for less than eleven percent of the total energy savings from the program.

The successful and the less successful aspects of the WRAP process as of 1989 are summarized in table ES-1. Since the time of the process evaluation, several modifications have been made to the program process to remedy deficiencies. Training programs have been expanded, quality control 


\begin{tabular}{||l|l||}
\hline \multicolumn{1}{|c||}{ TABLE ES-1 } \\
WRAP Design Evaluation Summary (1989) \\
\hline.$\quad$ Overall low-income weatherization \\
concept \\
Eligibility of households between 150\% \\
and 200\% of federal poverty levels \\
$\begin{array}{l}\text { Broad range of options } \\
\text { Structural flexibility }\end{array}$ \\
Compatibility with assisted housing
\end{tabular}

procedures have been intensified, and efforts have been made to better ensure adherence to utilitydeveloped measure priorities.

\section{Market Evaluation}

The market evaluation indicated that for both the 1988 and 1989 years of the program, actual units participating were less than the numbets that were projected to be completed. This was true also for program expenditures. However for the 1990 program year, numbers $\mathrm{if}$ actual participating units were very close to those set as a goal. The program expenditures were greater than the budget for 1990, largely due to the surpassing of the unit goals for plans E4 and E5. These plans are very comprehensive and allow for higher expenditure ceilings per dwelling than the remaining plans.

The 1989 participant demographics indicated that the program was divided fairly evenly between urban and rural participants ( 54 percent urban, 46 percent rural). However, the number of renter occupied dwellings exceeded the owner occupied units, 57 percent to 42 percent. The proportions for the 1990 program year varied a bit from that in 1989. Although the urban and rural splits were identical to that from 1989, the proportion of owner participant dwellings droppe' 1 to 38 percent versus 62 percent that were rented. In both program years, the predominant space heati ig fuels found for the participants were gas and oil. Electric space heating was accounted in 11 percent of the 1989 dwellings and 8 percent for 1990.

For both program years, the predominant measures installed were weatherstripping, water heater wraps, low flow showerheads and faucets, storm windows, and efficient light bulbs. The average expenditure per participant, for all the program plans was $\$ 260$ for 1989 and $\$ 502$ for 1990 . The increase in the average expenditure is principally due to the increased number of participants served under the higher expenditure limit plans E4 and E5 for 1990.

\section{Impact Evaluation}

Engineering estimates of lifetime electricity savings from the WRAP program are $6.5 \mathrm{GWh}$ from 1989 installations and $8.5 \mathrm{GWh}$ from 1990 installations. Corresponding first year electricity savings estimates are $861 \mathrm{MWh}$ and 1,173 MWh for 1989 and 1990 installations, respectively. In theory, electricity savings from 1991 installations should be higher (both overall and per participant) than from 
program years 1989 and 1990, because the frequency of lighting measure installation was relatively low in 1989 while the program was still "ramping up", and investment in furnace work for non-electric-spaceheating participants was elevated in 1990. Preliminary electricity savings estimates from partial-year 1991 installations (January through November) do show significant increases from 1989 and 1990 levels: 1.5 GWh saved in the first year and $10.7 \mathrm{GWh}$ saved over the lifetime of the measures.

Actual first year electricity savings (based on electric billing data) from 1989 installations indicate an increase in average consumption of $954 \mathrm{MWh}$. However, the program was still in its initial stages during this period. Actual first year electricity savings from 1990 installations are very close to the engineering estimates, at 1,052 MWh.

On a MMBts basis, electricity savings accounted for 9 percent of first year and 5 percent of lifetime energy savings from 1989 installations. In 1990, the percentage of energy saved as electricity fell to 7 percent for first year and 3 percent for lifetime. Preliminary engineering estimates of electricity savings for partial year 1991 (January through November) are significantly higher, at 15 and 11 percent of first year and lifetime energy savings, respectively.

Analyses of program impact on electricity use per participant are summarized in table ES-2 for both 1989 and 1990. Engineering estimates based on the number of measures installed within the participants' dwellings indicate that the program has the potential for saving, on average, $240 \mathrm{kWh}$ during the first year of measure use for the 1989 participants and $307 \mathrm{kWh}$ for the 1990 participants. The majority of these savings are found for those measures affecting electric space heating. Consistently, the urban participants had a greater potential for electricity savings than their rural counterparts (1989: urban 311, rural - $156 \mathrm{kWh}$; 1990: urban - 318, rural $295 \mathrm{kWh}$, per participant). Also, renters had higher potential average electricity savings (1989: owner -184 , renter $-282 \mathrm{kWh} ; 1990$ : owner -318 , renter $295 \mathrm{kWh}$, per participant).

However, analysis of actual electricity billing records indicated that the 1989 participants actually increased their energy use by $500 \mathrm{kWh}$, or 8 percent of their base use, on average and weather normalized. This result was largely due to increases in use by rural participants, as well as renters, those with gas and propane space heating and those within plans E1 and E3. As mentioned above, these results could be due to the fact that the program was still in its infancy, with general measure installation quality and comprehensiveness not yet maximized.

The 1990 electricity billing analysis shows results that are much more indicative of a maturing program. On average, the 1990 participants saved $346 \mathrm{kWh}$ or 5 percent of their base use, wearher normalized. The only participant subgroup that did not experience reduced electric energy use was that group with propane space heating. But, their increase was relatively minor at 3 percent of their base electricity consumption.

Comparing first year engineering estimates with actual electricity bill savings showed significant differences in all estimates for the 1989 participants. However, the 1990 estimates are remarkably similar to those actually determined for the first year of measure use. This may also be indicative of a mature program.

Table ES-3 summarizes the lifetime energy savings per participant, in Btus and based on the engineering estimates. Given the similarity between the 1990 first year engineering estimates and the savings actually found, the lifetime Btus are probably closer to reality for 1990 than for 1989 . In all, the 


\begin{tabular}{|c|c|c|c|c|c|c|}
\hline \multicolumn{7}{|c|}{$\begin{array}{c}\text { TABLE ES-2 } \\
\text { Summary of First Year Electricity Savings } \\
\text { Per Participant } \\
\text { Engineering Estimates vs. Actual } \\
\text { (kWh) }\end{array}$} \\
\hline \multirow{3}{*}{ Participan? } & \multicolumn{3}{|c|}{$19899 \ln 45118$ irous } & \multicolumn{3}{|c|}{1990 linstillations } \\
\hline & \multirow{2}{*}{ Epgintering } & \multicolumn{2}{|c|}{ 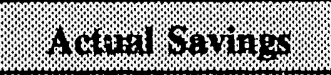 } & \multirow{2}{*}{ 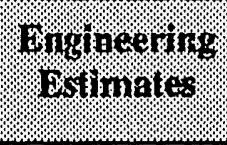 } & \multicolumn{2}{|c|}{ i curial savings: } \\
\hline & & 19176 & rerecent: & & rown: & Prercent \\
\hline Total & 240 & $(500)$ & (8) & 307 & 346 & 5 \\
\hline E1 & 192 & (12) & $(0)$ & 180 & 167 & 3 \\
\hline E2 & 61 & 238 & 3 & 117 & 59 & 1 \\
\hline E3 & 297 & (1259) & (23) & 470 & 645 & 8 \\
\hline $\mathrm{E} 4$ & 209 & 1435 & 18 & 215 & 226 & 3 \\
\hline E5 & 328 & 141 & 2 & 211 & 55 & 1 \\
\hline Urban & 311 & 554 & 8 & 318 & 478 & 7 \\
\hline Rural & 156 & $(1855)$ & (29) & 295 & 107 & 1 \\
\hline Owner & 184 & 678 & 9 & 223 & 169 & 2 \\
\hline Renter & 282 & $(1340)$ & $(23)$ & 360 & 461 & 7 \\
\hline $\begin{array}{l}\text { Electric Space } \\
\text { Heating }\end{array}$ & 1452 & 1563 & 12 & 1460 & 329 & 3 \\
\hline $\begin{array}{l}\text { Gas Space } \\
\text { Heating }\end{array}$ & 127 & $(1529)$ & (35) & 96 & 755 & 13 \\
\hline $\begin{array}{l}\text { Oil Space } \\
\text { Heating }\end{array}$ & 71 & (59) & (1) & 235 & 109 & 2 \\
\hline $\begin{array}{l}\text { Propane Space } \\
\text { Heating }\end{array}$ & 10 & $(1200)$ & (29) & 126 & $(210)$ & (3) \\
\hline
\end{tabular}




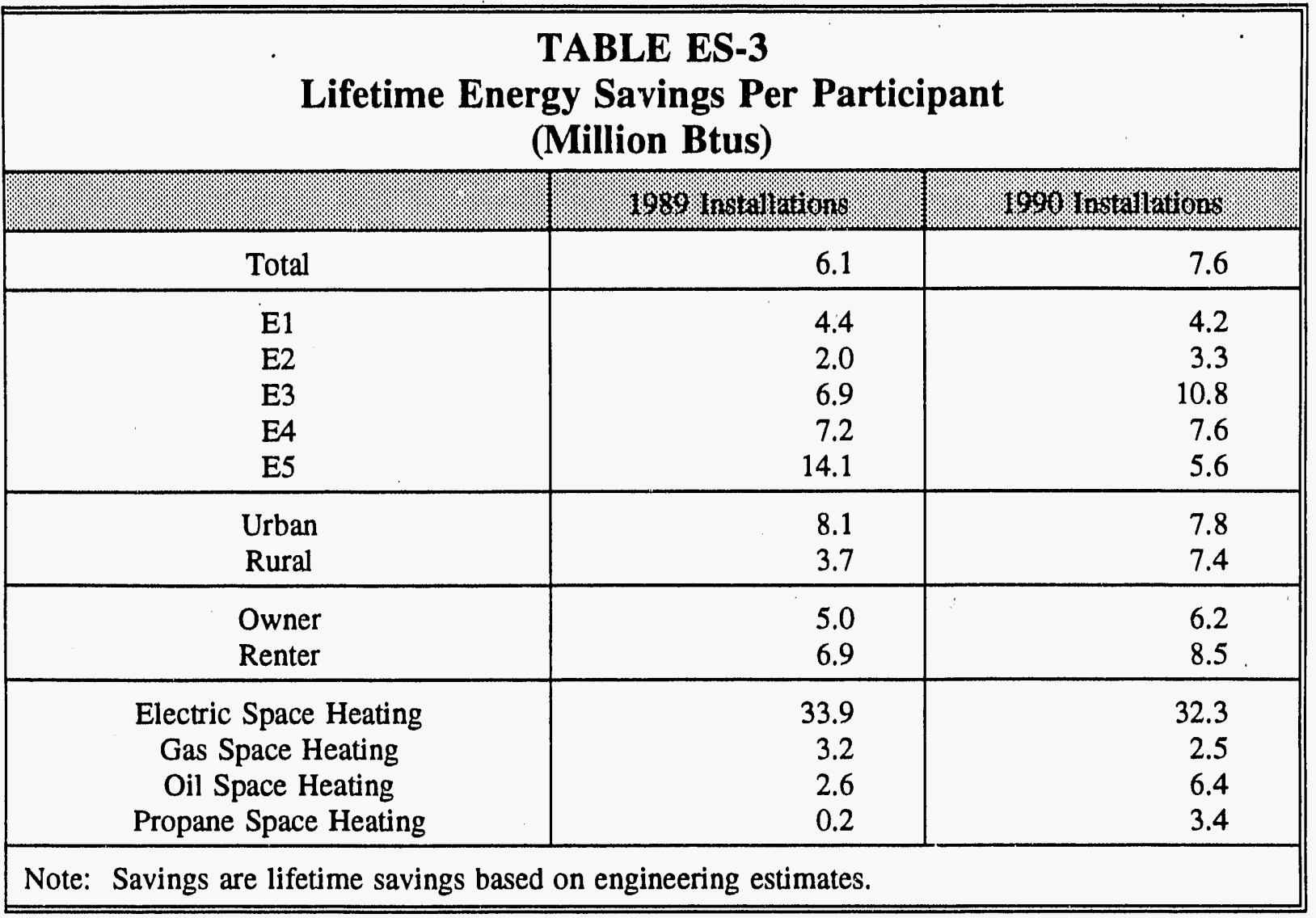

1990 participants have the potential for saving 7.6 million Btus of energy. Significant contributions towards these savings cam from those participants in plan E3, and those with electric space heating.

The program had a cost effectiveness, on average, of $\$ 0.10$ per $\mathrm{kWh}$ based on all program expenditures in 1989. This figure is $\$ 0.18$ per $\mathrm{kWh}$ for 1990 . These values are higher than the average residential electric rate per $\mathrm{kWh}$ because the expenditures include monies spent on measures that save other fuel types than electricity (primarily oil). When the cost effectiveness is viewed for those participants with electric space heating, the program cost is $\$ 0.02$ per $\mathrm{kWh}$ for both program years. This value is a more appropriate measure of the electricity cost effectiveness as it assesses mainly expenditures for electric measures. Similarly, the cost effectiveness of the program from the gas perspective indicates that the program cost $\$ 0.27$ per ccf in 1989 and $\$ 0.18$ in 1990 , on average. These costs are very similar to those also found for the gas space heating participants. The overall cost effectiveness of oil savings (costs include costs of electricity and propane saving measures) was $\$ 0.38$ per gallon in 1989 and $\$ 0.44$ per gallon in 1990. The cost effectiveness for participants with oil space heat was $\$ 0.28$ in 1989 and $\$ 0.37$ in 1990.

An analysis of the impact that the program had on participants' electricity bill arrearages indicated success. The program reduced the 1989 participant arrearages by an average of $\$ 9.73$ per month; the 1990 analysis showed an $\$ 18.77$ reduction, on average, on the participants' monthly arrearage. Larger arrearage reductions were found for the urban participants where they were reduced by an average of $\$ 11.75$ for the 
1989 participants and $\$ 20.23$ for 1990 . Rural results indicated an average reduction on monthly arrearage of $\$ 7.60$ for 1989 and $\$ 16.07$ in 1990 .

Given these results, the program demonstrates levels of success based nn the goals of energy savings and arrearage reduction. It is indicated that the 1989 participant results were not as clear as those for the 1990 participants. This may be true because, like the 1988 program year, 1989 was also a "ramp" year. Program maturity became evident in the results of the 1990 participant statistics. 


\section{CHAPTER 1 \\ INTRODUCTION TO THE WRAP PROGRAM}

This chapter presents the background information necessary for understanding the main body of this report. It begins with a general discussion of how and why the WRAP program came into existence, and continues with brief summaries of how the program has been implemented and administered, some specifics of program design, and how the program process functions.

\subsection{DEVELOPMENT OF THE WRAP PROGRAM}

Soon after utilities began implementing demand-side management (DSM) programs, there was some criticism that such programs were inherently biased against low-income cu.tomers. Because of their lack of disposable income, low-income customers were unable to participate in programs such as high-efficiency appliance rebates, and could not follow through on weatherization advice gained from an audit program. While customers in higher income brackets participated in programs that reduced their energy consumption and saved them money, the low-income customers, who were most in need of energy cost relief, did not directly benefit from the programs. However, as ratepayers, they still were forced to bear the costs of these programs. Because of this, utilities began to consider developing DSM programs especially targeted to the low-income customer.

There were several difficulties unique to low-income DSM programs that must be overcome for success. This sector is typically difficult to reach as these customers are often distrustful of utility representatives and utility programs. As mentioned above, they do not have tine financial resources available to invest in even low-cost conservation measures. From the utility standpoint, low-income programs generally do not pass traditional cost-benefit and cost-effectiveness tests in integrated resource planning due to relatively low achievable energy savings and high costs of the installed measures. Thus, past programs, while valuable for those who could participate, are limited by low participation rates, funding constraints, and a relative lack of program effectiveness. NU was always a leader in providing targeted programs for low-income customers as a segment of its conservation programs, and since 1983 had been contracting with Community Action Agencies to provide services to low-income customers.

The origins of the WRAP program itself began with the 1987 Northeast Utilities (Connecticut Light and Power Company) Rate Docket. Northeast Utilities (NU) had conducted low-income DSM programs for many years prior to this, and presented as part of the case a new screening methodology for DSM options, called the "Low Income Screening Matrix". This matrix was designed to identify the programs and options that best meet the needs of low-income and special needs gas and electric customers; not in terms of a strictly electric energy saving economic analysis, but in terms of many of the benefits (including customer and community benefits) that usually were not considered in cost/benefit analysis and the planning process. The results of this screening indicated that the most effective program for this target group was a no-cost comprehensive conservation services package.

Northeast Utilities also reported, at the rate hearing, on two pilot comprehensive services programs for payment-troubled customers with incomes at or below 200 percent of federal poverty levels. These programs included both an energy conservation education component and a budget management education component. In response to these reports, several intervenors presented an 
expert panel on conservation and load management, including members knowledgeable on low-income weatherization. These intervenors also asked that they be involved in the planning process for lowincome program design.

In response to this rate docket, the Connecticut Department of Public Utility Control (DPUC) directed NU and several intervenors to collaborate to produce a low-income weatherization program that would:

- Not ignore oil and gas savings.

- Be offered to customers at or below 200 percent of federal poverty levels.

- $\quad$ Provide a full range of services for heating, water heating, and lighting.

- Substantially increase the level of funding for weatherization services.

- $\quad$ Reduce auditing costs.

To meet these guidelines, as well as to overcome the barriers to implementation, participation, and cost-effectiveness, NU and Yankee Energy Systems (YES) collaborated with several state agencies and private organizations. The state agencies involved in the collaborative process were the Connecticut Office of Policy and Management/Energy Division, the Connecticut Office of Consumer Counsel, the Connecticut DPUC and its Prosecutorial Unit, and the Connecticut Deprartment of Human Resources. The private organizations included in the collaborative group were the Connecticut Association for Community Action and the Conservation Law Foundation. It was the goal of all the involved parties to develop an innovative, cost-effective program that would reduce the energy bills of low-income customers in New England and elsewhere.

As a symbol of the cooperative spirit of the participating organizations, the program that was developed through this collaborative process was called the "Weatherization Residential Assistance Partnership," or WRAP. The WRAP program was designed to provide comprehensive weatherization services to low-incone Connecticut residents, without cost to the participant. In addition to standard weatherization measures, the program offers the installation of measures to improve the efficiency of water heating, lighting, and other end-uses, as well to improve the efficiency of the furnace itself. Services are provided regardless of fuel type; the program is completely "fuel blind" during service delivery. The program was later joined by the Connecticut Natural Gas Company (CNG).

\subsection{PROGRAM IMPLEMENTATION}

Connecticut's Community Action Agencies (CAAs) were selected to implement the program and to assist the collaborative group in the development of a program design. The CAAs had been delivering conservation services to Connecticut's low-income community since 1974, and were already known and trusted by the low-income community. The CAAs were contracted by the State Department of Human Resources (DHR) and funded by the DHR, Petroleum Settlement monies and the Federal Department of Energy (US DOE). DHR monitored the work. Conn Save, a nonprofit organization that delivered residential auditing services for several utilities, joined with DHR and US DOE to provide training programs to update and train CAA crew members on state of the art equipment and new installation techniques. Half of the CAAs provided the majority of the conservation services, contracting out a few services that the crews could not provide; the others contracted out most services. 
Although the CAAs already provided a relatively comprehensive package of conservation measures to the low-income community, they did not offer any energy efficient lighting measures, an area of interest to NU. In addition, because public weatherization funds were limited, they were unable to provide some long-term, high-cost measures such as sidewall insulation, heating system replacement, or burner replacement, as frequently was required. Adding WRAP funds to the current sources of CAA funding provided an ideal opportunity for maximizing the cost-effectiveness of the program. The WRAP funds allowed the CAAs to begin providing some of the needed services that they were unable to provide in the past, services that promoted the objectives of the WRAP program, and WRAP was saved the expense of developing its own system of recruiting and installation.

The collaborative group developed a pooling system for all available funds. About half of the utility funds would be used jointly with public funds to enhance the weatherization services provided to clients identified and selected by the CAAs. NU proposed that all publicly funded units weatherized within the utility's service territory would, if appropriate, receive energy efficient light bulbs. For multiple unit dwellings, the cost of installation of fluorescent lighting fixtures would be paid exclusively by utility funds.

With utility funding, CAAs could now provide the major measures cited earlier. In addition, they could perform other major repairs to improve the integrity of the housing units so that the weatherization would be more effective.

The remaining half of the utility funds would be used for weatherization of households selected by the utility. A walk-through "needs analysis" was substituted for the regular Connecticut Residential Conservation Service (RCS) audit when appropriatc. This resulted in a major reduction in program auditing cost.

\subsection{PROGRAM MANAGEMENT}

Conn Save, the non-profit residential audit organization formed in support of the RCS audit, was initially chosen to serve as the administrative center for the program and to house the program funds contributed by the participating utilities. Conn Save was selected because it already had a working relationship with the implementing agencies (CAAs), and because NU and YES hoped that the neutrality of the organization and its location would appeal to other utilities who might be interested in joining the partnership. When Conn Save was dissolved in 1989, the Connecticut Housing Investment Fund (CHIF) was selected to house the WRAP Unit. CHIF already had experience with utility-sponsored low-income programs through the administration of the Energy Conservation Loan Program, wherein the interest costs of conservation loans are subsidized by the utilities. The CHIF/WRAP Unit administers WRAP and also handles the administration of the low income audit program for the five major gas and electric utilities in the state (the electric utilities also pay for all oil audits).

A single master contract design was agreed upon, although each CAA contracts separately with each utility. The contract established that the CAAs were to be paid a fee per audit/needs analysis, a fee per measure or actual cost plus labor, and an administrative fee. Other fees were to be paid if the CAA needed to obtain landlord permission for measure installation or if there was more than one "no show" by the customer at the time of service delivery. CAAs were offered advances upon request if they needed to purchase measure supplies to maintain their inventories. Through this arrangement and with the CAAs weatherization experience, the program began 
immediately upon signing of the contracts, without the lengthy start-up time required for some DSM programs. Utility low-income customers were served within a few days of the program start. The official program "kick-off" was September 1988.

Because of the collaborative nature of the program, it was evident from the onset that open communication and cooperative working relationships would be an integral part of the program administration in order to build a strong program. Towards this end, the following administrative structures were put into place:

- A "Steering Committee" would meet periodically to address policy issues and receive program updates.

- A Training and Technical Assistance Committee was established to build the crew capabilities for the program using utility and public funds. This committee was to meet monthly and develop a computerized weatherization tracking/monitoring program for the CAAs.

- Lead representatives of the collaborating organizations would meet monthly to solve problems in a cooperative rather than a confrontational manner.

Efficient program monitoring was also established as one of the administrative keys to program success. However, because there are so many organizations involved within the program and five different program plans, monitoring of the program could be burdensome. "Easy to use" work invoices were designed for the CAAs that allocated proper fees per program plan. It was determined early in the program development that quick access to all program data would be required by the administration. Minimal data coding was a requirement of all program field personnel. A PC-based tracking and reporting system allowed the program administration, the CAAs, and the utility representatives quick access to any program information - ranging from where a client record is located within the program installation reporting system, to the amount of energy saved per plan due to the installed measures. Also included in this system was a comprehensive "Quality Assurance Module" to monitor installation quality and to maintain the current high program standards.

ICF Resources was hired as the principle investigator for the WRAP program. ICF performed all program evaluation, assisted by Technical Development Corporation (TDC) and Steven Ferry Associates. A personal computer tracking system is used to track measure installation data. This PC system was designed to be one of the most comprehensive monitoring systems being utilized in any DSM program. It has since proved to be a valuable element of this program. Quick access to any program information is possible, reducing the amount of paperwork and hand tabulation typically required of such efforts. Invoice forms were standardized over the 5 program plans, also increasing ease of use. As such, this program monitoring system has served as a model for other DSM systems for other programs and utilities.

\subsection{PROGRAM DESIGN}

The WRAP program serves each participant under one of five plans (E1 through E5). The plans are differentiated based on measures provided, overall investment level, and customer eligibility requirements. There are currently forty-seven distinct measures available under the WRAP program, representing the most comprehensive conservation package of any DSM program in Connecticut. 
Table 1-1 lists the individual measures and indicates how the five plans differ in terms of the measures they provide. An " $\mathrm{X}$ " indicates that the measure is provided by that plan. (Measures 2 and 3 were lighting measures; they were later split out into more specific bulb and fixture types and became measures 33 through 39 . Measures 40 through 49 are recent additions to WRAP.) These measures were selected through the review of the Conn Save residential audit database and the in iight of the NU/YES regional community relations representatives, CAA program managers, and the collaborating organizations. They range from the traditional low-cost infiltration and water heating measures, to significant ceiling and wall insulation additions as well as full furnace replacement. 


\begin{tabular}{|c|c|c|c|c|c|c|c|}
\hline & $\begin{array}{r}\text { TABI } \\
\text { leasures Available for Weath } \\
\text { Partnership }\end{array}$ & $\begin{array}{l}\text { 1-1 } \\
\text { RAzation Re } \\
\text { PAP Prog }\end{array}$ & $\begin{array}{l}\text { den } \\
\text { im }\end{array}$ & al & ist & & \\
\hline Measure & Description of Measure & Type of & & & Availg & & \\
\hline $\begin{array}{l}\text { Coae } \\
\text { Number }\end{array}$ & & & $\mathbf{E 1}$ & $\mathbf{E 2}$ & $\mathbf{E 3}$ & $\mathbf{E 4}$ & $\mathbf{E 5}$ \\
\hline 1 & Set Water Heater Thermostat & Water Heating & $\mathrm{x}$ & & $\mathrm{x}$ & $\mathrm{x}$ & $\mathrm{X}$ \\
\hline 4 & Electric Outlet Gasket & Heating & $\mathrm{x}$ & & $\mathrm{x}$ & $\mathrm{x}$ & $\mathrm{x}$ \\
\hline 5 & Low-Flow Showerhead & Water Heating & $\mathrm{x}$ & & $\mathrm{x}$ & $\mathrm{x}$ & $\mathrm{x}$ \\
\hline 6 & Wrap Water Heater & Water Heating & $\mathrm{X}$ & & $\mathrm{x}$ & $\mathrm{x}$ & $\mathrm{x}$ \\
\hline 7 & Low-Flow Faucet Aerator & Water Heating & $\mathrm{x}$ & & $\mathrm{x}$ & $\mathrm{X}$ & $\mathrm{x}$ \\
\hline 8 & Door Sweep & Heating & $\mathrm{x}$ & & $\mathrm{x}$ & $\mathrm{x}$ & $\mathrm{x}$ \\
\hline 9 & Caulk Window & Heating & $\mathrm{x}$ & & $\mathrm{X}$ & $\mathrm{X}$ & $\mathrm{X}$ \\
\hline 10 & Caulk Exterior Door & Heating & $\mathrm{X}$ & & $\mathrm{x}$ & $\mathrm{X}$ & $\mathrm{x}$ \\
\hline 11 & Weatherstrip Window & Heating & $\mathrm{X}$ & & $\mathrm{X}$ & $\mathrm{X}$ & $\mathrm{x}$ \\
\hline 12 & Weatherstrip Door & Heating & $\mathrm{X}$ & & $\mathrm{x}$ & $\mathrm{x}$ & $\mathrm{x}$ \\
\hline 13 & Insulate Attic Hatchway & Heating & $\mathrm{X}$ & & $\mathrm{X}$ & $\mathrm{X}$ & $\mathrm{x}$ \\
\hline 14 & Interior Caulk & Heating & $\mathrm{X}$ & & $\mathrm{x}$ & $\mathrm{X}$ & $\mathrm{X}$ \\
\hline 15 & Basement Window Covering & Heating & $\mathbf{X}$ & & $\mathrm{X}$ & $\mathrm{X}$ & $\mathrm{X}$ \\
\hline 16 & Insulate Heating Duct & Heating & $\mathrm{X}$ & & $\mathrm{x}$ & $\mathrm{X}$ & $\mathrm{x}$ \\
\hline 17 & Insulate Vertical Attic Door & Heating & $\mathrm{x}$ & & $\mathrm{x}$ & $\mathrm{X}$ & $\mathrm{X}$ \\
\hline 18 & Tube Pipe Insulation & Water Heating & $\mathbf{X}$ & & $\mathrm{x}$ & $\mathrm{X}$ & $\mathrm{x}$ \\
\hline 19 & Sill Plate Caulk & Heating & $\mathrm{x}$ & & $\mathrm{x}$ & $\mathrm{x}$ & $\mathrm{x}$ \\
\hline 20 & Insulate Pull Down Stair & Heating & $\mathrm{X}$ & & $\mathrm{X}$ & $\mathrm{X}$ & $\mathrm{x}$ \\
\hline $21^{\mathrm{B}}$ & Replace Filter for Gas/Oil Warm Air System & Heating & & & & $\mathrm{x}$ & $\mathrm{X}$ \\
\hline 22 & Hole in Wall & Heating & & & & $\mathrm{x}$ & $\mathrm{X}$ \\
\hline 23 & Calibrate/Replace Thermostat & Heating & & & $\mathrm{X}$ & $\mathrm{X}$ & $\mathrm{X}$ \\
\hline $24^{\mathrm{a}}$ & Vent Damper (gas) & Water Heating & & & & $\mathrm{x}$ & $\mathrm{X}$ \\
\hline $25^{\mathrm{a}}$ & Pilotless Ignition System (gas) & Other & & & & $\mathrm{X}$ & $\mathrm{X}$ \\
\hline 26 & Increase Ceiling Insulation Level & Heating & & & & $\mathrm{X}$ & $\mathrm{X}$ \\
\hline 27 & Replace Broken Window/Door Glass & Heating & & & $\mathbf{X}$ & $\mathrm{X}$ & $\mathrm{x}$ \\
\hline 28 & Window Treatment & Heating & & & & $\mathrm{X}$ & $\mathrm{x}$ \\
\hline
\end{tabular}




\begin{tabular}{|c|c|c|c|c|c|c|c|}
\hline \multicolumn{8}{|c|}{$\begin{array}{l}\text { TABLE } 1 \text {-1 (continued) } \\
\text { Measures Available for Weatherization Residential Assistance } \\
\text { Partnership (WRAP) Program }\end{array}$} \\
\hline \multirow{2}{*}{$\begin{array}{l}\text { Measure } \\
\text { Code } \\
\text { Number }\end{array}$} & \multirow[t]{2}{*}{ Description of Measures } & \multirow{2}{*}{$\begin{array}{l}\text { Type of } \\
\text { Measure }\end{array}$} & \multicolumn{5}{|c|}{ Plan Availability } \\
\hline & & & E1 & $\mathrm{E2}$ & E3 & $\mathrm{E} 4$ & E5 \\
\hline 29 & Heating System Repairs & Heating & & $\mathrm{x}$ & & $\mathrm{x}$ & $\mathrm{x}$ \\
\hline 30 & Burner Replacement & Heating & & $\mathrm{x}$ & & $\mathrm{x}$ & $\mathbf{x}$ \\
\hline 31 & Furnace Replacement & Heating & & $\mathrm{x}$ & & & $\mathrm{X}$ \\
\hline 32 & Sidewall Insulation & Heating & & $\mathrm{x}$ & & & $\mathrm{x}$ \\
\hline 33 & Fluorescent Compact Bulb 18W & Lighting & $\mathrm{x}$ & & $\mathrm{x}$ & $\mathbf{x}$ & $\mathrm{x}$ \\
\hline 34 & Fluorescent Twin Bulb 13W & Lighting & $\mathbf{x}$ & & $\mathrm{x}$ & $\mathrm{x}$ & $\mathrm{x}$ \\
\hline 35 & Fluorescent Quad Bulb 22W & Lighting & $\mathbf{x}$ & & $\mathrm{x}$ & $\mathrm{x}$ & $\mathrm{x}$ \\
\hline 36 & Fixture $22 \mathrm{~W}$ & Lighting & $\mathbf{x}$ & & $\mathrm{x}$ & $\mathrm{x}$ & $\mathrm{x}$ \\
\hline 37 & Fixture 32W & Lighting & $\mathrm{x}$ & & $\mathrm{x}$ & $\mathrm{x}$ & $\mathrm{x}$ \\
\hline 38 & Circline Fixture 40W & Lighting & $\mathrm{x}$ & & $\mathrm{x}$ & $\mathrm{x}$ & $\mathrm{x}$ \\
\hline 39 & Fixture $54 \mathrm{~W}$ & Lighting & $\mathrm{x}$ & & $\mathrm{x}$ & $\mathrm{x}$ & $\mathrm{x}$ \\
\hline $40^{\mathrm{a}}$ & Window Replaccment & Heating & & & & $\mathrm{x}$ & $\mathrm{x}$ \\
\hline 41 & Clean, Tune, and Test & Heating & & $\mathrm{x}$ & & $\mathrm{X}$ & $\mathrm{x}$ \\
\hline 42 & Minor Plumbing & Water Heating & & & $\mathrm{x}$ & $\mathrm{x}$ & $\mathrm{x}$ \\
\hline 43 & Miscellaneous & & & & $\mathrm{x}$ & $\mathrm{x}$ & $\mathrm{x}$ \\
\hline 44 & Spiral Pipe Insulation & Water Heating & $\mathbf{x}$ & & $\mathrm{x}$ & $\mathrm{x}$ & $\mathrm{x}$ \\
\hline 45 & Window Lock & Heating & & & $\mathrm{x}$ & $x$ & $\mathrm{x}$ \\
\hline 46 & Gas Company Ceiling Insulation & Heating & $\mathrm{x}$ & & & $\mathrm{x}$ & $\mathrm{x}$ \\
\hline 47 & Fixture 30 Tube & Lighting & $\mathbf{X}$ & & $\mathrm{x}$ & $\mathrm{x}$ & $\mathrm{X}$ \\
\hline 48 & Fixture 40 Watt & Lighting & $\mathrm{x}$ & & $\mathrm{x}$ & $\mathrm{x}$ & $\mathrm{x}$ \\
\hline 49 & Fixture 50 Watt & Lighting & $\mathrm{X}$ & & $\mathrm{X}$ & $\mathrm{X}$ & $\mathrm{x}$ \\
\hline $\begin{array}{l}\text { These } \\
\text { Note: Th } \\
\text { A differe } \\
\text { including }\end{array}$ & $\begin{array}{l}\text { easures }(21,24,25) \text { were eliminate } \\
\text { measure codes listed in this table cc } \\
\text { codification system is used on the }\end{array}$ & $\begin{array}{l}\text { he measure co } \\
\text { d on other W }\end{array}$ & & & & & \\
\hline
\end{tabular}


While the public funds for the WRAP program are available only to households with incomes at or below 150 percent of federal poverty levels, the collaborators recognized that households just above this threshold, with incomes between 150 and 200 percent of federal poverty levels, also might have difficulty benefiting from traditional DSM programs. This group, also known as the "working poor", often includes families just above the qualifying thresholds for many assistance programs, including Fuel Assistance. Other members of this group might include elderly individuals on fixed incomes or handicapped customers. In addition to serving the working poor, Northeast Utilities also wanted to continue to offer its "open enrollment" program (providing low-cost heating and water heating services plus window glass repair and thermostat replacement) to its seriously delinquent customers, and to develop other comprehensive services projects for customers in need. The five plans of the program were developed to meet all of these program goals. Table 1-2 summarizes the eligibility requirements and investment levels of each plan.

\subsection{PROGRAM PROCESS}

This section summarizes the process through which the WRAP program functions. The following sub-sections discuss eight distinct aspects of the program process.

\section{Customer Identification and Recruitment}

Plan E1 and E2 participants are current Fuel Assistance recipients and Weatherization Assistance Program (WAP) customers, recruited to the WRAP program by CAAs.

Plan E3, E4, and E5 participants are selected by the utility. Recruitment is based on an examination of billing records to identify seriously delinquent accounts ( $\$ 200$ or more in arrears). The utility also uses workshops, mailers, and social service referrals for recruiting potential participants.

CAAs view the E1 and E2 plan recruitment method as a means of providing more comprehensive conservation services to low-income households which would be treated through WAP in any case. However, the E3, E4, and E5 utility recruitment approach allows the CAAs to reach more households than through WAP alone. The E3, E4, and E5 programs also allow them to refer households which include a member who is elderly or handicapped, have a household income between 150 and 200 percent of federal poverty levels, and are participating in the State Appropriated Fuel Assistance Program. In 1990, the CAAs referred to the utility over one hundred households who were WAP eligible but needed furnace replacements. This practice has recently been halted because of the burden it placed on utility funds. In 1991, DOE provided $\$ 50,000$ in "leveraging" funds to match utility funds for furnace replacement through plan E2. 


\begin{tabular}{|c|c|c|c|}
\hline \multicolumn{4}{|c|}{$\begin{array}{l}\text { TABLE } 1-2 \\
\text { WRAP Plan Descriptions }\end{array}$} \\
\hline Plan & Customer Eligibility Requirements & $\begin{array}{l}\text { Initial Investment Level } \\
\text { Guidelines }\end{array}$ & Audit Information \\
\hline $\mathbf{E} 1$ & $\begin{array}{l}\text {. Income at or below } 150 \% \text { of } \\
\text { federal poverty levels } \\
\text { - High use of Energy Assistance } \\
\text {. High energy use } \\
\text { - Priority to elderly/handicapped }\end{array}$ & $\begin{array}{l}\text { Up to } \$ 150 \text { per household, } \\
\text { investment can be higher for } \\
\text { certain measures }\end{array}$ & $\begin{array}{l}\text { "Portable audit" supplied by } \\
\text { utility funds }\end{array}$ \\
\hline E2 & $\begin{array}{l}\text { - Income at or below } 150 \% \text { of } \\
\text { federal poverty levels } \\
\text { - High use of Energy Assistance } \\
\text { - High energy use (primarily oil) } \\
\text { - Priority to elderly/handicapped }\end{array}$ & Average of $\$ 600$ per household & $\begin{array}{l}\text { "Portable audit" supplied by } \\
\text { utility funds }\end{array}$ \\
\hline $\mathbf{E 3}^{\mathbf{a}}$ & $\begin{array}{l}\text { Income at or below } 200 \% \text { of } \\
\text { federal poverty levels } \\
\text { Includes non-English speaking } \\
\text { persons, families with children, } \\
\text { elderly }\end{array}$ & $\begin{array}{l}\text { Up to } \$ 225 \text { per household, } \\
\text { investment can reach as high as } \\
\$ 475 \text { for certain measures }\end{array}$ & $\begin{array}{l}\text { Needs analysis provided by } \\
\text { utility funds }\end{array}$ \\
\hline $\mathbf{E} 4^{\mathbf{b}}$ & $\begin{array}{l}\text { - Income at or below } 200 \% \text { of } \\
\text { federal poverty levels } \\
\text { - Customer's account is seriously } \\
\text { delinquent }\end{array}$ & $\begin{array}{l}\text { Maximum of } \$ 1,500 \text { per } \\
\text { household. In } 1990 \text {, maximum } \\
\text { was } \$ 3,000 \text { for furnace } \\
\text { replacement. }\end{array}$ & $\begin{array}{l}\text { "Portable audit" supplied by } \\
\text { utility funds }\end{array}$ \\
\hline $\mathbf{E 5} 5^{\mathbf{b}}$ & $\begin{array}{l}\text { Income at or below } 200 \% \text { of } \\
\text { federal poverty levels } \\
\text { Critical need present for } \\
\text { households with incomes between } \\
150 \% \text { and } 200 \% \text { of federal } \\
\text { poverty levels } \\
\text { High gas heat or electric/gas } \\
\text { general service use }\end{array}$ & $\begin{array}{l}\text { Up to } \$ 1,500 \text { per household. } \\
\text { In } 1990 \text {, maximum was } \$ 3,000 \\
\text { for furnace replacement. }\end{array}$ & $\begin{array}{l}\text { "Portable audit" supplied by } \\
\text { utility funds }\end{array}$ \\
\hline a/ & 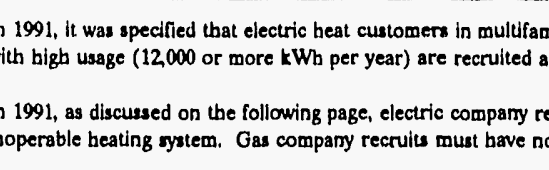 & $\begin{array}{l}\text { ily housing with electricty unage of } 7,000 \mathrm{kWh} \text { per y } \\
\text { dd referred to the company's Spectrum program. } \\
\text { cruits must have bigh electric general service usage } \\
\text { more than one or three inches of celling insulation. }\end{array}$ & $\begin{array}{l}\text { ar are to be setved under WRAP. Customen } \\
2000 \text { or more kWb) or an unsale or } \\
\text { depending on wbilch gas company is involved. }\end{array}$ \\
\hline
\end{tabular}




\section{Audit/Energy Survey}

The processing of customer audits varies by plan, but all audits use the same audit design. Audit invoice forms for the plans are located in Appendix G. The audits for plans E1 and E2 are initiated by the CAAs. Participants of these plans receive the same audit performed for WAP participants. Completed audits are forwarded to the CHIF/WRAP Unit for processing, and returned to the CAAs with the results.

Audits for the other plans are initiated by the CHIF/WRAP Unit. Plan E3 participants receive a walk-through analysis rather than a full audit. This type of analysis checks for the presence or lack of certain weatherization measures. If the CAA crew performing the walk-through identifies a need for repairs of measures not provided under plan E3, a recommendation is made that the customer receive an upgrade to plan E5. If this assessment is confirmed by the CAA energy auditor, the upgrade research is initiated. The auditor performs the more complete energy audit used under plans E1, E2, E4, and E5; this may occur as soon as the regional utility representative gives verbal approval to the upgrade, before the official work order is issued. Most participants of plan E5 were recruited to the plan based on upgrades from plan E3. The criteria for plans E4 and E5 was revised in 1991. If the electric company (CL\&P) is to be the prime funder, then there must be a high electric general service usage $(12,000 \mathrm{kWh}$ or more per year) or an unsafe or inoperable heating system that cannot be repaired or replaced with public funds. For Yankee Energy Systems to be the prime funder, there must be less than three inches of ceiling insulation; Connecticut Natural Gas sets the limit at one inch.

Many E4 and E5 participants are recruited through direct mail or gas company referral. If the customer is referred by a social service agency (e.g. a CAA), the application is sent to the regional utility representative and double-checked for eligibility. Once eligibility is confirmed, participants receive the same audit performed for plans E1 and E2. As for the other plans, completed audits are forwarded to' the CHIF/WRAP Unit for processing and returned to the CAAs with the results.

In 1990, a new "portable audit" created by Community Energy Partnership and EACI of Boston, Massachusetts was selected to replace the WAP-style audit previously used for plans E1, E2, E4, and E5. The "portable audit" was selected primarily because of its strong educational component.

\section{Landlord-Tenant Relations}

A key characteristic of the service area served by the WRAP program is that approximately 36 percent of the households consist of renters. This percentage is even higher among low income households and WRAP clients (see chapter 3 ). Landlord approval is required before any audits could be performed or measures could be installed. For plan E4 and E5 participants, utility regional community relations representatives have the responsibility for obtaining this permission. The CAAs obtain landlord approval for E1 and E2 plan customers, since they act as the recruiters for these plans.

\section{Customer Education}

Under the WRAP program's current operation, customer education takes place both in the recruitment stage and during the actual audit of the household. Utility community relations 
representatives use local energy education workshops to recruit clients as well as educate on conservation. The workshops ("HEAT", "Energy Bingo", "Managing on a Shoestring", and "Energy Care") are typically presented to groups consisting of the elderly and others brought together by social service agencies. The "portable audit" currently used in plans E1, E2, E4, and E5 has a strong conservation education component. Additionally, a subset of 1991 participants (about two hundred) are receiving "WRAP-Plus", a supplementary program wherein the auditor sets specific energy conservation action goals with the customer. These goals are discussed again by the person doing quality assurance.

\section{Delivery of Weatherization Services}

The full audits are processed by the CHIF/WRAP Unit and the results are forwarded to the appropriate CAA, which then assigns a crew to install the measures specified by the audit. The measures available under plans E3, E4, and E5 are prioritized by the utility based on cost effectiveness. High priority measures are to be installed if they meet the audit requirements. However, this is not always done. Compliance is being tracked and reported on a monthly basis in 1991 to increase the cost effectiveness of the program. Some CAAs contract with independent contractor/installers, while others maintain their own installation staff. Because of the less in-depth nature of the walk-through audits performed for plan E3, the CHIF/WRAP Unit processing is omitted and measures can be installed any time after the walk-through.

All weatherization measures are targeted to be in place within a ninety day period from the work order (which requests the CAA to schedule an audit or walk-through). This period is only tracked for plans E3, E4, and E5, since audits for the E1 and E2 plans are initiated by the CAA rather than the CHIF/WRAP Unit.

\section{Quality Control}

Once measures are installed in WRAP households, a field inspection of the provided services is performed by an outside inspection organization. In 1991, a change was made so that two percent of inspections are done by an outside organization, and the balance by the CHIF/WRAP Unit. The CHIF/Wrap Unit inspects ten percent of E1 installations, thirty-three percent of E2 installations, twenty percent of E3 installations, and one hundred percent of E4 and E5 installations. The DHR also has monitors who inspect E1 and E2 installations as part of the WAP quality control. Since the size of the utility investment in E4 and E5 households is quite large, the one hundred percent inspection rate is considered to be justified. Inspectors identify installation problems and help assure that accurate completion of the audit checklist is achieved. A computerized check of audit findings against priorities and installed measures gives one hundred percent coverage as of mid-1991.

\section{Billing and Record Keeping}

For all plans, the checklists which are used to outline the priorities of the measures to be addressed in a household also serve as a record of the work to be completed as well as an invoice. The CAAs bill the CHIF/WRAP Unit monthly for the audits completed under each separate plan. The CHIF/WRAP Unit pays the CAAs a flat fee of $\$ 50$ per audit. The utilities pay the CHIF/WRAP Unit \$72/audit. The balance goes for the royalty and CHIF/WRAP Unit administrative costs. This represented a lower total cost than the utilities paid for other audit contractors who participate in the balance of the RCS program. The CAA checks the number of measures installed 
and, based on the unit cost of those measures, computes a total billing amount. Total costs for materials and labor are added along with a ten percent administrative fee. In some cases, such as lighting fixture replacement in which a subcontractor performs the work, an additional ten percent is added to the unit cost to cover this arrangement. (This latter payment was revised in 1991 to a $\$ 1$ per fixture fee to support cost containment in installation costs.)

The CHIF/WRAP Unit totals the WRAP installation invoices by CAA for each plan on a monthly basis. A single check is issued monthly to each CAA from the WRAP account established by each company with CHIF. CHIF reports the expenditures, and the WRAP Unit then reports back to the companies regarding the completed work. Approximately twenty-five various data reports for electric services are processed monthly and disseminated to NU central administration and regional offices, with similar information going to the gas companies regarding their customers.

\section{Monitoring and Modification Mechanisms}

The CHIF/WRAP Unit has primary monitoring responsibilities for WRAP program operations. This is primarily accomplished through their tracking of the timeliness of installations (for E3, E4, and E5 plan participants) and the quality assurance reports. Problems and opportunities for program improvement are brought to the attention of a Working Committee, which meets periodically to make recommendations to the Steering Committee. The Steering Committee meets shortly thereafter (one or two weeks later). During the first two years of WRAP, meetings were almost monthly. Currently in program year four, the DHR Training and Technical Assistance Committee meets monthly, the WRAP Working Committee meets quarterly, and the Steering Committee meets on a semi-annual basis.

The WRAP program is under the oversight of the Connecticut Department of Public Utility Control (DPUC), which approved the basic program design and is concerned about reaching the targeted number of households. While WRAP, as a low-income program, is not evaluated on the basis of cost per kWh savings as in other DSM programs, the DPUC has indicated that it would like to see a greater emphasis on electricity savings. Additionally, the DPUC has indicated that the program should be evaluated based on the cost effectiveness of savings for each fuel, if costs are allocated according to fuel. 


\section{CHAPTER 2 \\ Development, Design, and Process Evaluation}

This chapter includes three separate evaluations, intended to address three program elements which answer the following questions:

Development Evaluation (evaluates how the program was developed)

Were the processes through which WRAP was developed appropriate to the goals at hand?

Did these processes work effectively?

Design Evaluation (evaluates the structure of the program)

Is the program design fundamentally sound? This includes such questions as:

- Is the concept of a low-income weatherization program justifiable?

. Are the eligibility requirements appropriate?

- $\quad$ Are the appropriate options available?

- Does the program contain sufficient flexibility to be able to respond to lessons learned through program experience?

Are there any aspects of program design that are notable for their success or lack thereof?

Process Evaluation (evaluates how the program functions internally)

Does the paperwork flow smoothly and efficiently?

Do the people involved do their jobs efficiently and effectively?

The evaluations are based on the findings of two independent research teams ${ }^{1}$, whose collective research included a literature review, a survey of selected WRAP participants, an analysis of customer records, a set of interviews with members of the collaborative process ${ }^{2}$, and a set of interviews with individuals familiar with the design, management, and delivery of the WRAP program.

\subsection{DEVELOPMENT EVALUATION}

The process by which thie WRAP program was developed included both a DSM option screening methodology, set forth by Northeast Utilities (NU), and the Connecticut Collaborative Process. The basis

1 Their reports are included as companion documents, entitled WRAP Program Evaluation, Steven Ferry, 1990, and Process Evaluation, Weatherization Residential Assistance Partnership (WRAP Program), Technical Development Corporation, October 1990. Key documentation from these reports is included in Appendix G.

2 These interviews were used exclusively for the evaluation of the collaborative process approach. To encourage honesty and full disclosure, interviewees were guaranteed full anonymity. 
for the WRAP program design was NU's screening methodology, which integrated the goals of the utility, their low-income customers, and the low-income community as a whole. This approach was found to be appropriate and effective; no new concepts or technologies have emerged since that time to justify a revision of the screening methodology.

The details of the WRAP program were developed as part of a larger collaborative process in the state of Connecticut. A range of participants worked with the collaborative process, and overall results were good. A full analysis of the collaborative approach appears in the companion report, WRAP Program Evaluation, Steven Ferry, 1990.

\subsection{DESIGN EVALUATION}

Table 2-1 summarizes the key findings of the design evaluation. Overall, the program design was very successful. Current research supports the validity of low-income weatherization programs. There is some criticism that the effectiveness of weatherization programs is compromised by the "take-back" effect. This would orcuir if customers increase their consumption of energy after the weatherization service in response to the resuling lower energy bill. However, evidence suggests that the "take back" effect is minimal, at best. With little or no "take back" effect, all benefits from weatherization should work effectively to reduce consuinption and arrearage.

In addition to the quantifiable utility goals of energy savings and arrearage reduction, WRAP was designed to meet other goals of the customers and the low-income community. The results of the WRAP participant survey indicate that the program successfully achieved several of its qualitative objectives. Sixty five percent of survey participants reported that they felt more comfortable in their homes since the weatherization. Over ninety fiv's percent rated Northeast Utilities' service as good or very good, and almost half said that their opinion of their local utility company was better than it had been prior to the installation (forty six percent said that their opinion was unchanged).

Econometric research has found that self-initiated energy conservation does occur as a result of changes in the price of energy, and that increases in energy costs cause low-income households to reduce energy consumption more than affluent households. Behavior and attitude changes, as opposed to conservation investments, are credited for causing this energy reduction. Renters also tend to reduce consumption more than owners, again as a result of behavior modification. Investment in energy conservation measures is the more common response in affluent households due to the availability of investment funds.

These findings are important for the review of WRAP's design because they support the provision of utility-sponsored conservation measure installation for a potentially untapped low-income market, which includes a large portion of renter households. The research indicates that low-income households and tenants do not generally respond to price signals by installing conservation measures. Instead, they make lifestyle and behavioral changes at a rate greater than average in response to higher electricity prices and conserve far beyond the population norm. Therefore, conservation measures are more likely to have a greater impact in low-income households because the homes are in greater need. In addition, if lowincome customers are generally more flexible in their energy-use behaviors, as this research indicates, then they may be more likely to change their behavior in response to participation in a conservation program. Thus, utilities are justified in using conservation programs to support and reinforce low-income and tenant customer efforts to enact lifestyle changes. The implied greater flexibility of renters supports the WRAP program's efforts in targeting low-income renters. 


\begin{tabular}{||l|l||}
\hline \multicolumn{1}{|c||}{ TABLE 2-1 } \\
WRAP Design Evaluation Summary
\end{tabular}

One of the particularly commendable aspects of WRAP's design is that the eligibility requirements for three of its five plans allow for participation by households whose incomes fall between 150 and 200 percent of federal poverty levels. These households have many of the same needs as households below 150 percent of poverty, but are ineligible for most assistance programs, including the Weatherization Assistance Program, and thus represent a needy but largely untapped market.

The choice of options available under the WRAP program is in line with recommendations in the current literature. The large number of options is a particularly positive aspect of WRAP, because it allows for a better fit between services provided and the needs of each participant household. Research also indicates that those programs with the widest range of measures provide the greatest savings.

Lighting fixture replacement, while an important priority for the utility, has achieved only mixed success as an option. NU determined that a unit-by-unit lighting fixture replacement was not feasible, so it implemented major lighting retrofit projects in selected large low-income housing developments. Some public housing authorities have expressed an interest in program participation; however, several recipients of these fixture retrofits were dissatisfied. Northeast Utilities reports that since this survey, participant reaction has improved due to the installation of fixtures that provide light levels equivalent to those replaced; earlier dissatisfaction was due to reduced lighting levels. Lighting measures continue to be the utility's best alternative for increasing the ratio of electricity savings to total energy savings which result from the WRAP program.

Originally, WRAP did not have a very strong energy conservation education component. The education that was provided was limited to the implementation process. Participants of plans E1 and E2 often received educational guidance through the other programs in which they are involved, plan E3 participants were often recruited through utility educational workshops, and Community Action Agency (CAA) analysts discussed conservation measures and behavior when conducting audits. General literature on the subject (see Appendix G) suggests that a strong educational component can increase low-income weatherization savings by four to eight percent, or up to fifty percent when education is targeted to higharrearage customers. In light of these findings, the educational component of WRAP has been expanded. A packet of educational materials is mailed to WRAP participants and, as discussed in chapter 1, the. "portable audit" approach was initiated in late 1990 and increases education levels for all E1, E2, E4, and E5 participants. A subset of these participants now takes part in the "WRAP-Plus" program as well, which 
supplements existing energy education offerings. The educational component for E3 participants has not changed, but Northeast Utilities is currently seeking to enhance the education levels received by this group of participants.

The WRAP program process has proven to be responsive to the realities of the conditions "in the field". There have numerous adaptations in the program's design since its start, demonstrating its responsiveness. For example, at one point it became clear that a large portion of the payment troubled customers targeted for plan E4 participation also had significant heating system repair and replacement needs. This required that some E4 customers be upgraded to the E5 plan to address their needs. Ultimately, the maximum expenditure allowed for E4 participants was increased to the E5 level to resolve this situation. Additionally, the WRAP program has the flexibility to address specific household situations in which the energy needs must be handled with additional measures.

Another favorable aspect of the WRAP program is that it is well-designed to work with assisted housing. The federal government, under the Brooke Amendment to the National Housing Act, established a "30 percent" statute in which low-income tenants pay a maximum of 30 percent of their income to cover rent and utility expenses for the household. There are two different categories of assisted housing that fall under this statute: public housing and Section 8 housing.

Public housing is federally owned and supplied to low-income tenants. In public housing, the 30 percent portion of the tenant's income covers all rent and utility bills. All other expenses are paid by the Department of Housing and Urban Development (HUD) and the Public Housing Authority (PHA).

Section 8 housing is privately owned, and incentives are provided to building owners so they will rent the apariments to low-income residents. For these residences, the PHAs establish a "fair market rent," consisting of a rent component and a utility allowance. This difference between this amount and 30 percent of the tenant's income is paid directly to the landlord by HUD. In theory, the tenant pays 30 percent of their income, less the utility allowance, directly to the landlord, and the amount of the utility allowance to the utility. If the utility bill is the same as the utility allowance, the tenant pays exactly 30 percent of their income to rent and utilities. However, utility bills are frequently higher than allowances, and the 30 percent rule is exceeded regularly for Section 8 tenants. It is estimated that approximately three-fourths of Section 8 tenants receive an inadequate utility allowance.

The underestimation of utility allowances is primarily caused by poor monitoring. The allowances may underestimate the actual utility bills for all or part of the year, and do not reflect actual building behavior in months of extreme weather. Without aggressive monitoring, the allowances cannot be accurately adjusted. Also, on a unit-by-unit basis, individually metered households vary in their rent and utility burdens. Some households may have total burdens of approximately 30 percent, but in certain months, others spend more than 100 percent of their adjusted incomes on rent and utility expenditures.

Another possible explanation that has been suggested is that the PHAs, in an effort to stimulate more participation in the Section 8 program, tend to suppress the utility allowance component of their fair market rent. This effectively gives a relatively larger subsidy amount to the private market landlord who participates in the Section 8 program. This may benefit tenants by bringing better quality housing into the Section 8 market than otherwise would be offered, but it hurts tenants by requiring them to pay more than the mandated percentage of their income for Section 8 shelter. 
These problems also occur in standard public housing as well as Section 8 housing, but to a lesser degree because public housing is more closely monitored by the PHA. Also, PHAs establish a more accurate aggregate utility allowance, and thus rent burden, for its public housing than for its Section 8 housing.

Energy conservation, as embodied in the WRAP program, constitutes a critical resource for federally assisted urban and rural housing. First, because the WRAP program does not require building owner funding, it is particularly attractive to Section 8 owners. Second, because WRAP conservation measures narrow the dispersion of consumption and normalize consumption distribution, they effectively inject more equity into public housing and Section 8 utility subsidy schemes, regardless of how they are administered. Third, because of its structure, WRAP is attractive to owners, low-income tenants, and housing officials.

The funding of the WRAP program is an issue which may concern future WRAP program design. Presently NU is the major utility providing financial support to the WRAP program. NU is allowed by the DPUC to recover all WRAP program costs through its electric rates, even though approximately only five percent of the WRAP energy savings were for electricity in 1989 and $3 \%$ in 1990 . NU Community Relations can justify the WRAP program because of its apparent contribution to increasing NU's payment rate among its low-income customers. However, it is not evident that WRAP, as a fuel blind program primarily supported by an electric utility, can be justified entirely on economic grounds.

Presently, all program participants are committed to keeping WRAP a fuel blind program. Some financial contributions by gas utilities have been obtained and expansion is being discussed. Initial legislation has been passed to obtain oil company participation, but there is some feeling that revision is needed to strengthen the requirement. One DPUC official suggested that the ideal model would be a program that is fuel blind in its menu of measures, but the distribution of the costs for the various measures would occur among electric, gas, and oil contributors based on fuel type. In the meantime, the 1991 limit of $\$ 1,500$ for plans E4 and E5 participants means that the dwelling owners will have to pay for any needed conservation measures that surpass the plan monetary ceilings. In response to this, CAA staff and utility regional representatives are becoming knowledgeable about available conservation loan options that can be recommended to the dwelling owners.

\subsection{PROCESS EVALUATION}

Table 2-2 summarizes the process evaluation, indicating those aspects of the program process that were successful, as well as those areas evaluated in 1989 as needing improvement. Overall, the program process functioned fairly smoothly. There were only a few problems with the paper-flow within the program. With respect to invoice processing, Conn Save personnel ${ }^{3}$ identified several difficulties ir interpreting the invoices which some CAAs submitted. One source of problems was whether accountability of inputs or outputs was required by the various participants. CAAs accounted for inputs (for example, feet of caulking), as required by the Connecticut Department of Human Resources and the Department of Energy. NU wanted to account for outputs (for example, number of windows caulked). This issue was resolved by having the CAAs report to NU on the output basis, which is the unit for payment.

3 The process evaluation was conducted in early 1990, before Conn Save was disbanded.

(3) ICF Resources Incorporated

b102427.31

Page 2-5 


\begin{tabular}{|c|c|c|}
\hline \multicolumn{3}{|c|}{ 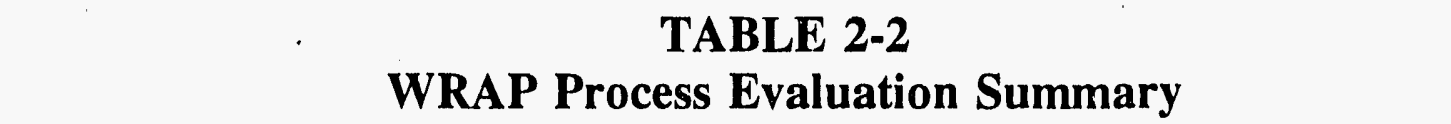 } \\
\hline Prooress? & Surgerstil 1 ripects. & 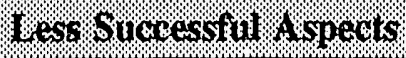 \\
\hline Paper-flow & $\begin{array}{l}\text { Application processing } \\
\text { Audit processing } \\
\text { Work order processing } \\
\text { Data report preparation }\end{array}$ & $\begin{array}{l}\text { Invoice Processing } \\
\text { Customer Tracking }\end{array}$ \\
\hline $\begin{array}{l}\text { Individual/ } \\
\text { Corporate } \\
\text { Performance }\end{array}$ & $\begin{array}{l}\text { NU commitment } \\
\text { State and community } \\
\text { involvement } \\
\text { Communication between } \\
\text { decision-makers and } \\
\text { implementers } \\
\text { Conn Save management } \\
\text { Conn Save responsiveness } \\
\text { CAA recruitment } \\
\text { Customer satisfaction }\end{array}$ & $\begin{array}{l}\text { Audit scheduling } \\
\text { Audit performance } \\
\text { Installation quality } \\
\text { CAA training } \\
\text { CAA billing } \\
\text { Measure selection }\end{array}$ \\
\hline
\end{tabular}

Customer tracking is another area of the program process that was identified as needing improvement. While plan E3, E4, and E5 service periods were tracked from the date the work order was issued (requesting the CAA to schedule an audit) to the date the CAA completed the delivery of services and submitted a payment invoice, plan E1 and E2 customers (for whom the CAA initiated the audit) did not have a tracking system. Additionally, Conn Save did not track the date it received the audits for processing. Interviews revealed that the time required to schedule and complete the audits varied substantially from one CAA to another. This suggested that there might be opportunities to share the successful management techniques of certain CAAs to improve the "speed" of others.

Since the initial process evaluation, several of these issues have been addressed. The WRAP Unit currently records the date each audit request is received, and training has been provided to the CAAs through seminars sponsored by the DHR Training and Technical Assistance Committee. The WRAP Unit still does not report on the speed of delivery of E1 and E2 services, since that is controlled by the CAAs and the DHR.

The performance of the organizations and individuals involved with WRAP was largely successful. NU's contribution to the computerization of the weatherization systems of the participating CAAs should improve the area's non-profit, low-income energy service infrastructure's management capabilities. The active involvement of state and community agencies with the utility and Conn Save was also successful; their common commitment to the reduction of energy bills within the low-income community enabled these organizations to overcome their differences and work together effectively. The level and quality of communications between all of these groups were strong. There was satisfaction expressed on the part of the utility, CAA representatives, and the DPUC regarding Conn Save's role in administering the WRAP program. Interview comments revealed that Conn Save's management was accessible and responsive to the various needs that have surfaced. 
The plan-by-plan activity record of the WRAP program shows that participation in plans E1 and E2, the CAA-recruited plans, were under target for 1989 (table 2-3), and participation in plan E1 fell even shorter of target in 1990, despite the fact that the goal remained almost the same. This resulted from an over-estimation of the number of units that could be treated with public funds and underutilization of the E1 program by most CAAs. Goal revision and strong monitoring by the WRAP unit should help to alleviate this imbalance in the future.

According to the survey of program participants, utility activities accounted for only thirty-two percent of recruitments (see table 2-4). These findings were not consistent with the final plan assignments for these customers; approximately seventy percent of those surveyed were in the utility-recruited plans (E3, E4 or E5). This reflects a high number of State Appropriated Fuel Assistance clients and referrals of customers needing major heating system work. Interviews revealed that the use of Community Action Agencies is considered a major benefit of the WRAP program's design because of the CAAs' marketing and service delivery experience and the developed level of trust which they have in the low-income community. The CAAs are clearly viewed as being more effective than for-profit contractors in marketing to the low-income customer.

Survey respondents indicated a high level of satisfaction with their participation in the WRAP program. Few respondents (less than ten percent) claimed that the auditor did not come on the scheduled audit date or that the audit was less than thorough. Respondents overwhelmingly indicated that their auditor was courteous and helpful in explaining energy saving concepts to them. For those who were left with written materials to review, ninety-five percent said they found the information useful. Similarly, most respondents were either very satisfied or somewhat satisfied with installation work. Approximately ninety percent of the respondents indicated that the installers came when they were scheduled and completed their work within the advised time frame.

Despite these favorable aspects of the program process, there are several areas where improvements should be made. The WRAP Unit under Conn Save had mixed success in enforcing the ninety day time limit between the date of the work order (requesting the scheduling and performance of an audit) and the completion of the installation. This has been the case even for the best-performing CAAs.

One CAA solved this problem by sending a series of three letters at ten day intervals to those households that were not reached and scheduled through telephone contact. The letters requested that the customers contact the CAA directly to schedule an audit appointment. If the customer did not respond after the three letters, the work order request was returned to the WRAP Unit, thus "eliminating" the problem. While this may be a method which merely shuffles the customer back to the original point of contact, it does flag customers who are particularly difficult to reach so that an extensive amount of effort is not spent on attempting to schedule their audit. The WRAP Unit now requires monthly reports on the reasons for delay for all work orders at least seventy-five days old. For most of the CAAs, this has resulted in a reduction of the number of units serviced in more than ninety days; however, continued attention is required.

Another problem was that the WRAP Unit under Conn Save held work orders in batches for delivery to the CAAs, resulting in an uneven flow of work requests. For example, twenty work orders might have come through on the same day, each with the same ninety day time requirement. The CHIF/WRAP Unit has since eliminated this problem by forwarding work orders on a daily basis. 


\begin{tabular}{|c|c|c|c|c|c|c|c|}
\hline \multicolumn{8}{|c|}{$\begin{array}{l}\text { TABLE } 2-3 \\
\text { Number of Participants as a Percentage of Year-End Goal }\end{array}$} \\
\hline \multirow{2}{*}{\multicolumn{2}{|c|}{ Parn. }} & \multicolumn{2}{|c|}{ farrivil year 1988} & \multicolumn{2}{|c|}{1089.} & \multicolumn{2}{|c|}{1980} \\
\hline & & 4arringing & rergent & 4ear gind & fercent. & Year & $\begin{array}{l}\text { Percent } \\
\text { or Goal }\end{array}$ \\
\hline E1 & & 500 & $20 \%$ & 1,548 & $94 \%$ & 1,600 & $63 \%$ \\
\hline $\mathrm{E} 2$ & & 50 & $6 \%$ & 270 & $89 \%$ & 300 & $128 \%$ \\
\hline E3 & & 750 & $106 \%$ & 1,998 & $82 \%$ & 1,811 & $91 \%$ \\
\hline E4 & & 50 & $0 \%$ & 487 & $52 \%$ & 400 & $162 \%$ \\
\hline E5 & & 150 & $83 \%$ & 97 & $205 \%$ & 200 & $251 \%$ \\
\hline Total & & 1,500 & $68 \%$ & 4,436 & $85 \%$ & 4,311 & $97 \%$ \\
\hline \multicolumn{8}{|c|}{$\begin{array}{l}\text { Sources: 1988: "An Experiment in Cooperation: The Connecticut Low-Income Weatherization Program WRAP," Sara } \\
\text { S. Ellison et al, published in Partnerships in Planning, Demand-Side Management National Conference } \\
\text { - Proceedings, Electric Council of New England, Boston, MA, November 1989. } \\
1989 \text { and 1990: WRAP Unit monthly WRAP TRACK Program Financial Goals/Status Reports. }\end{array}$} \\
\hline
\end{tabular}

\begin{tabular}{|c|c|}
\hline \multicolumn{2}{|c|}{$\begin{array}{l}\text { TABLE } 2-4 \\
\text { Method of Recruitment }\end{array}$} \\
\hline Metilno & rercentage \\
\hline NU Representative Contact & $19 \%$ \\
\hline Utility Mailing & $13 \%$ \\
\hline Community Action Agency & $14 \%$ \\
\hline Other Social Service Agency & $13 \%$ \\
\hline Word-of-Mouth & $11 \%$ \\
\hline $\begin{array}{l}\text { Other (newspaper, Fuel Assistance program, } \\
\text { distributed literature) }\end{array}$ & $30 \%$ \\
\hline TOTAL & $100 \%$ \\
\hline \multicolumn{2}{|c|}{$\begin{array}{l}\text { Source: Survey of 1988-1989 WRAP participants. See Technical Development Corporation, } \\
\text { Process Evaluation, Weatherization Residential Assistance Partnership (WRAP Program), } \\
\text { Northeast Utilities, October } 1990 .\end{array}$} \\
\hline
\end{tabular}


Another factor which delays WRAP implementation is the waiting period for certain specially ordered measures, particularly windows. While this is a common obstacle which contributes to delays for all parties involved, it is not recognized to be a major problem.

The performance of the E4 and E5 audits depends largely on whether auditors are paid on a peraudit basis or on an hourly wage basis. These audits would not ordinarily be done as part of the Weatherization Assistance Program (WAP), but the added work of these audits does not justify hiring additional personnel. Agencies which contract with the state for full-time auditors on an hourly basis show a much greater reluctance to perform E4 and E5 audits than agencies which pay their own auditors a flat rate per audit. Auditors who are paid by the audit are generally pleased to have the additional Friday and Saturday work generated by the plan E4 and E5 audits. In 1991, there has been no substantial delay in performing audits.

The quality of installations is another area in need of improvement. For survey respondents who reported that their WRAP installations were inspected by a representative of the utility (thirty-nine percent of all respondents), nearly fourteen percent indicated that the inspectors found problems for which a return of the installer was warranted. Commonly identified problems needing to be fixed among these customer respondents are presented in table 2-5. Of the few households which indicated there were some problems with their installation of measures, nearly half had been resolved by the time the survey was completed.

These installation problems may indicate a need for more intensive training. Although NU's sponsorship of training programs has been an asset to the program, several research findings point to training deficiencies among CAA management, staff, and crews. For example, under-billing by the CAAs is not uncommon, and stems from the misidentification of work performed as well as from simple calculation errors. This suggests the possibility of illiteracy or innumeracy among CAA crew members, an issue that is somewhat difficult to resolve within the scope of the WRAP program. Since the survey was conducted, NU has continued to place a high priority on training. Recent training addressed heating systems, auditing, adult education techniques applied to conservation education, caulking techniques, and processing forms.

The quality control mechanisms established by WRAP management have been helpful in tracking and addressing quality problems. Quality control is vital in any program, but especially so in a program that involves so many differing groups for implementation. The fact that there are several Community Action Agencies (CAAs) contracted to perform the audits and needs assessments as well as install the necessary energy-savings measures naturally results in varying qualities of installation. The WRAP program manager felt it necessary to initially review the quality of the instaliations and the level of participant satisfaction as an aid in determining the training needed over the course of the program.

To facilitate this objective, inspections were performed monthly to determine specific areas where error was made in installation or where disagreements were found relative to installation technique. This process was employed from the initiation of the program through July 1991 and was accomplished using an inspection vendor. Currently, the WRAP Unit provides their own inspections using staff from the CAAs. The inspections are performed on completions from the month before. Any questionable or faulty workmanship found has been identified and corrected, if possible. When areas are identified with consistent problem, retraining in installation is performed. Although that took place several times during the initial stages of the program, problems are less common now. 


\begin{tabular}{|c|c|}
\hline \multicolumn{2}{|c|}{$\begin{array}{c}\text { TABLE } 2-5 \\
\text { Commonly Identified Installation Problems }\end{array}$} \\
\hline Problen & Percent of Respondents Wfio Indicated \\
\hline Insufficient insulation & $38 \%$ \\
\hline Window or door not replaced & $31 \%$ \\
\hline Water heater not wrapped & $13 \%$ \\
\hline Door would not close after insulation & $13 \%$ \\
\hline
\end{tabular}

With the current program activity, quality control inspections are performed on samples of customers from each program plan. The samples are chosen from each of the five participating regions of the state and involve agencies where installation quality has declined or where there have been participant complaints. Client complaints are based on quality assurance questionriaires that the customer is requested to complete. All WRAP participants are mailed this questionnaire that requests information regarding the installers' behavior, professional manner, and general customer satisfaction relative to the job. This returned data is input to the WRAP datat ase computer system where an average rating for each $\mathrm{CAA}$, each measure installation, each program plan and the total program (per agency) is calculated. Monthly quality control reports are then generated which leads to an evaluation of the quality and accuracy of the installed measures per agency. Over the course of the program, trends in measure ratings have emerged. On site training is developed or recommendations are made where required. When quality has improved, special note is made in reporting to the CAAs.

This activity has been valuable in the functioning of the program as it has alleviated problems, diverted other potential problems, and has allowed for positive feedback to be made to the CAAs and installers. This process is expected to continue throughout the life of the program to maintain a high degree of quality installations so that energy savings potential is maximized.

During the course of the process evaluation interviews, it was expressed by Conn Save that some CAAs, or their subcontractors, do not follow NU's priority scheme when selecting measures for installation. Conn Save staff speculated that incentives as perceived through the cost reimbursement scheme do not necessarily coincide with NU priorities. Whether true or not, the number of WRAP program lighting measure installations is not as high as the utility would like. This may be at least partially due to the fact that some CAAs seem to be less familiar with lighting applications, again indicating a need for additional training. These problems have been addressed by the CHIF/WRAP Unit by issuing monthly letters which compare measures installed to audit findings and utility priorities. Additionally, a lighting manual was prepared and a lighting workshop held. These steps seem to have resulted in increased levels of electricity savings. Estimated average lifetime electric savings per unit in January through November of 1991 (3.1 MWh) is seventy three percent higher than the average savings per unit in $1989^{4}$.

4 Source: WRAP Energy Savings Summary Report (January through November 1991) and November 1991 Program Financial Goals/Status Report from the CHIF/WRAP Unit. 


\section{CHAPTER 3 \\ MARKET EVALUATION}

Market evaluation seeks to answer the question, "Who did the program reach?" Inherent in this question is "Did the program effectively reach the people it was supposed to reach?" Section 3.1 assesses program activity from its initiation through the end of 1990, and shows how effectively WRAP met its targets in terms of participation and budget. Section 3.2 takes a closer look at who the program reached by examining some of the characteristics of program participants. Section 3.3 discusses the weatherization needs of participants, and simultaneously the needs that were met by the WRAP program. Finally, section 3.4 presents the average expenditures per participant for various participant categories. This section examines whiether WRAP benefitted certain participant groups more than others, whether intentionally or unintentionally, by spending a disproportionately higher share of resources on them.

\subsection{PROGRAM ACTIVITY}

The WRAP program began installations in September of 1988; figure 3-1 summarizes the program activity in the final months of that year. Plan E3, which was essentially a continuation of the pre-existing Northeast Utilities WRAP-UP/SEAL-UP program, was the only plan to meet its target number of installations. The large majority of 1988 participants took part under plan E3. Because the other plans started more slowly than expected, the WRAP program was seriously under target and under budget for 1988, despite the fact that the goals had been adjusted downward during the final months of 1988 .

In 1989, the WRAP program began to gain momentum. Almost four thousand installations were performed, at a cost approaching one million dollars (see figure 3-2). Plans E1 through E3 came very close to meeting their targets, and most participants were in plans E1 and E3. Plans E4 and E5 did not begin to account for significant numbers of installations until the last few months of 198911 ; despite this, Plan E5 more than doubled its targeted number of installations.

It was not until 1990 that all of the WRAP plans were up to speed (see figure 3-3). By the beginning of 1990 the WRAP paper process had become routine, staff members of local community action agencies (CAAs) were familiar with the range of WRAP services, and installers were familiar with the more complicated measures involved with plans E4 and E5. Units treated under plans E4 and E5 increased dramatically from 1989 levels and far exceeded target levels. The least intensive of the plans, plan E1, finished well under target, with roughly two-thirds the number of installations performed in 1989. As a whole, the WRAP program was very close to target in terms of number of households treated, but over budget because the percentage of installations under the more expensive plans E4 and E5 was mech higher than anticipated. This may indicate that weatherization needs in the service territory were more severe than had been anticipated based on 1989 plan activity.

1/ For additional reference, Appendix A contains information on monthly costs and number of installations. 
FIGURE 3-1

1988 WRAP Program Activity

\section{Unit Goals and Installations}

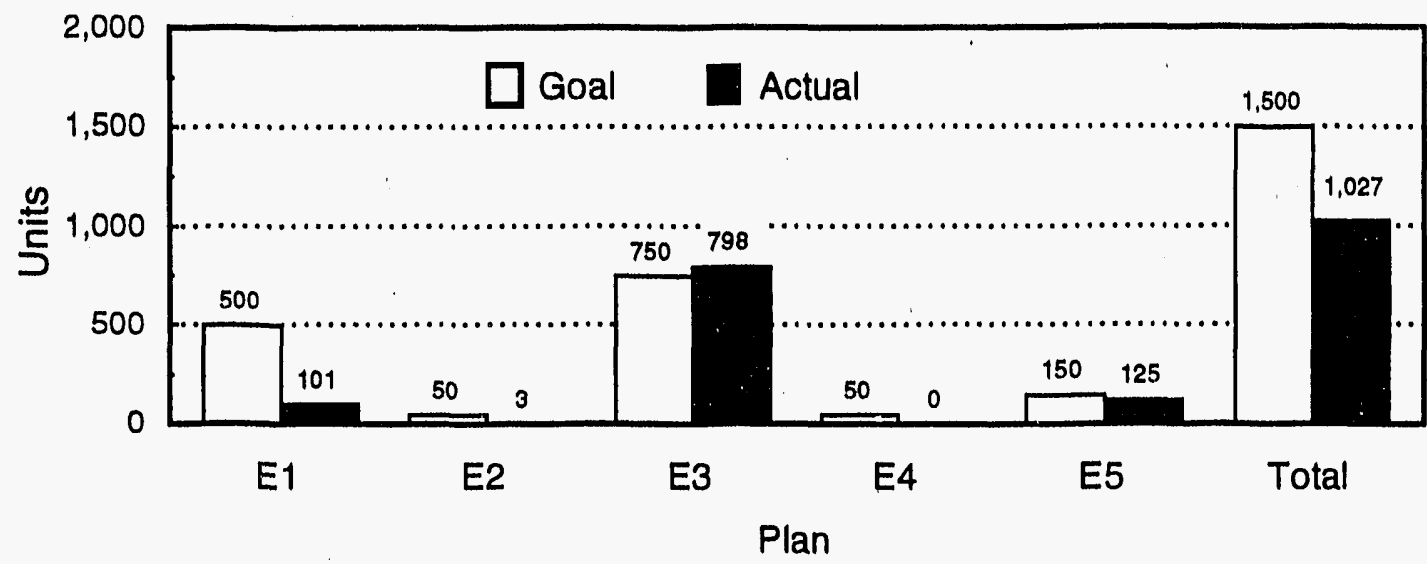

\section{Budget and Actual Costs}

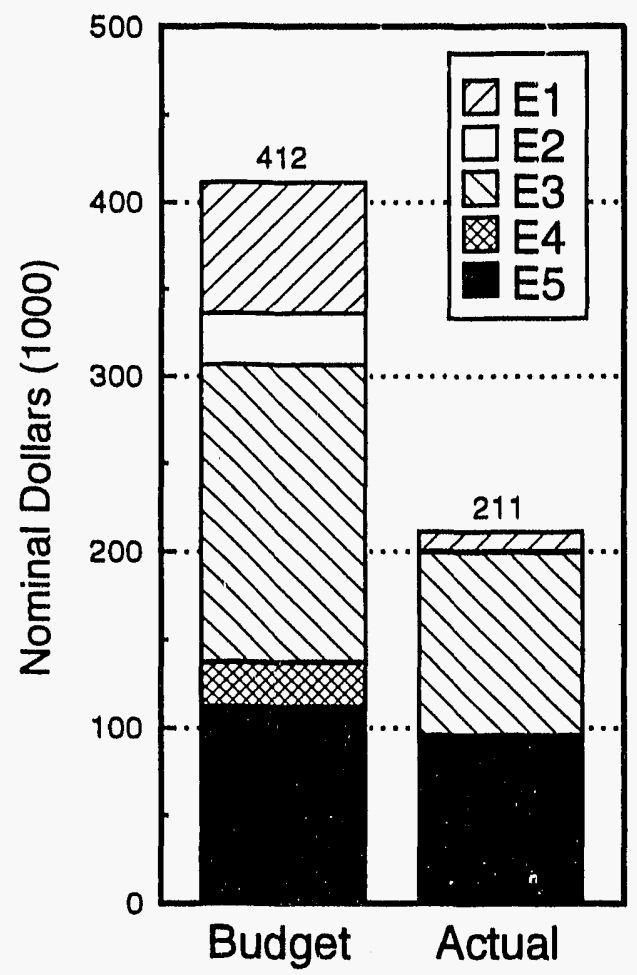

Participation by Plan

$($ Total $=1,027)$

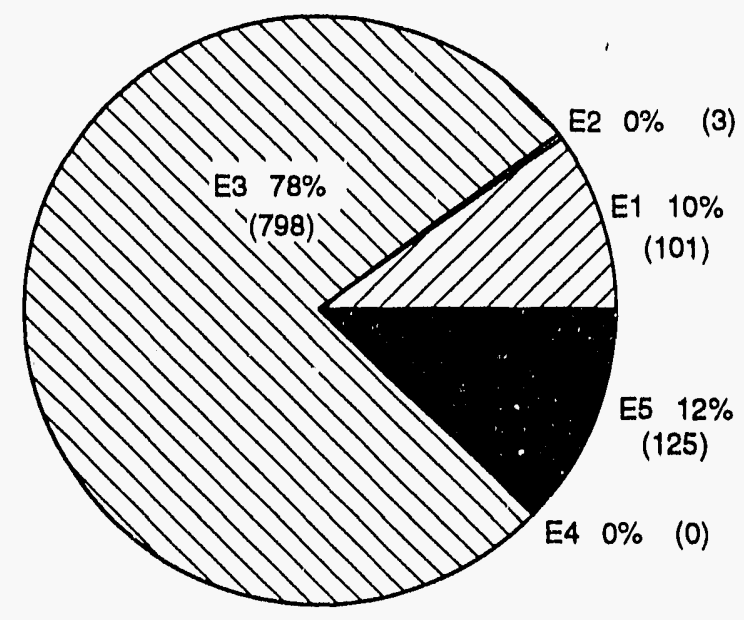

b102427.3PWrapes 
FIGURE 3-2

1989 WRAP Program Activity

\section{Unit Goals and Installations}

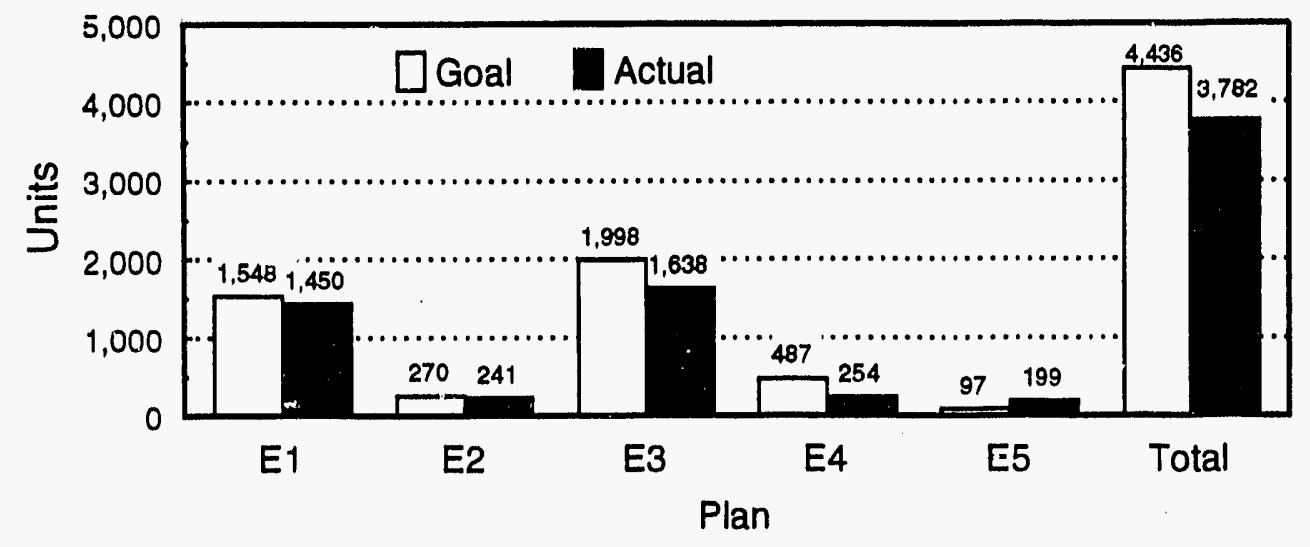

\section{Budget and Actual Costs}

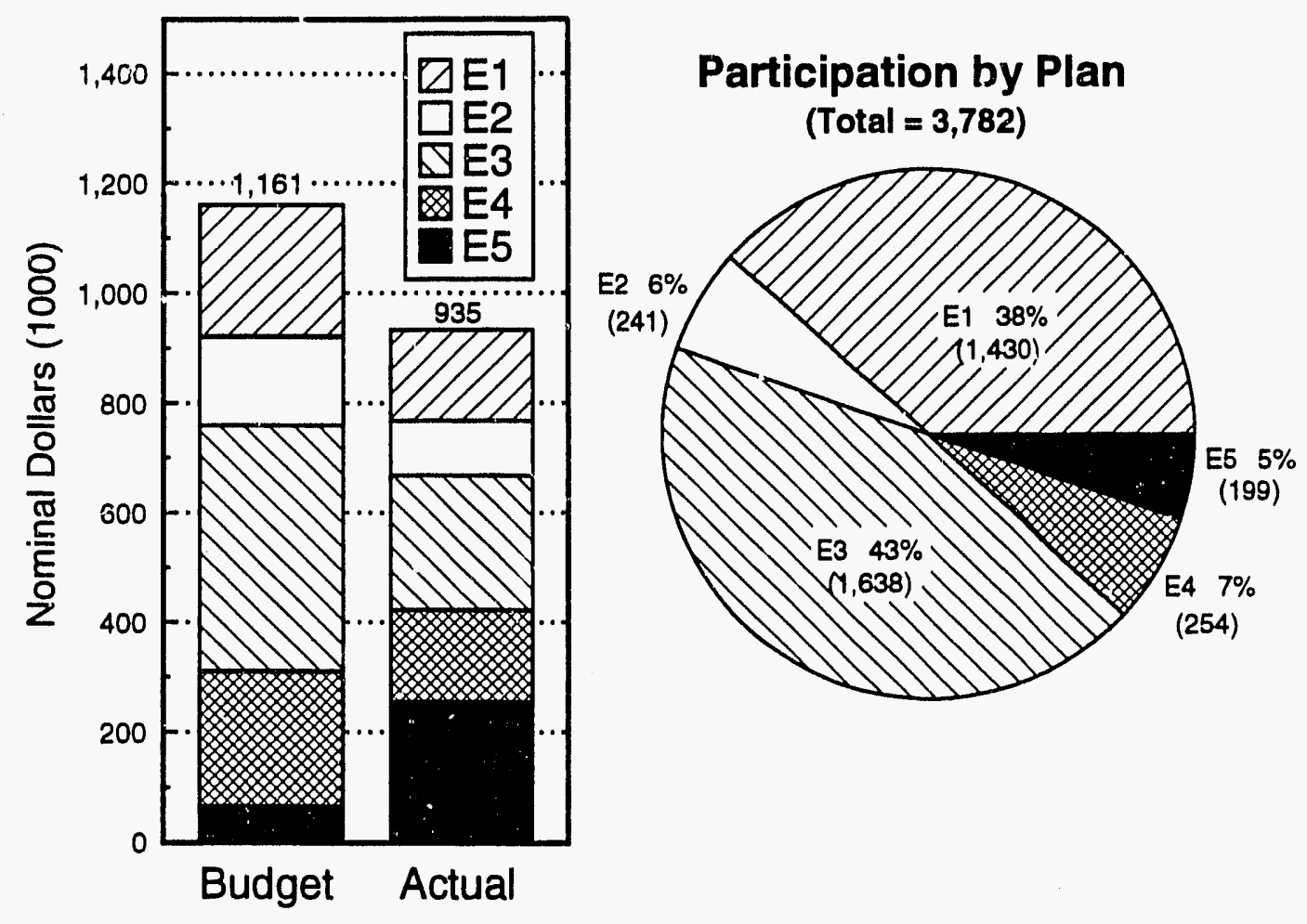

bN02427.3Fimapes 
FIGURE 3-3

1990 WRAP Program Activity

\section{Unit Goals and Installations}

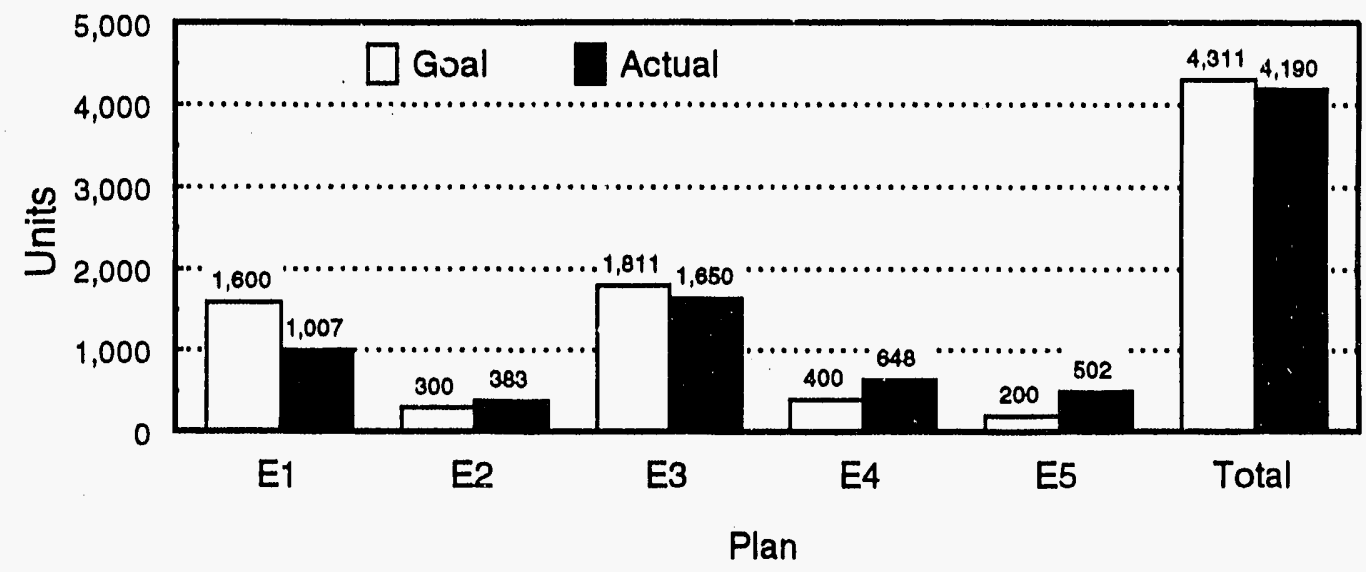

Budget and Actual Costs

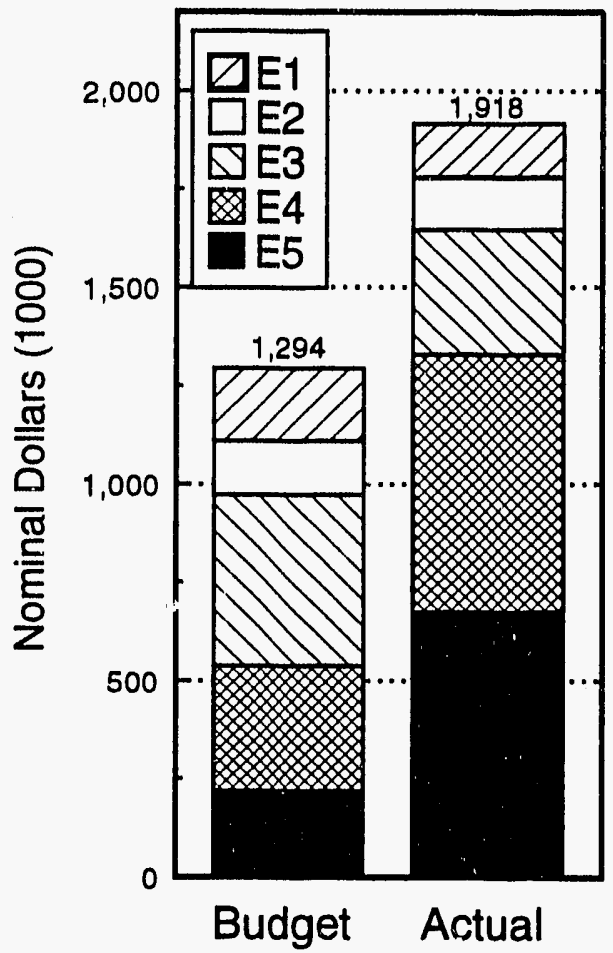

Participation by Plan

(Total $=4,190)$

E2 $9 \%$

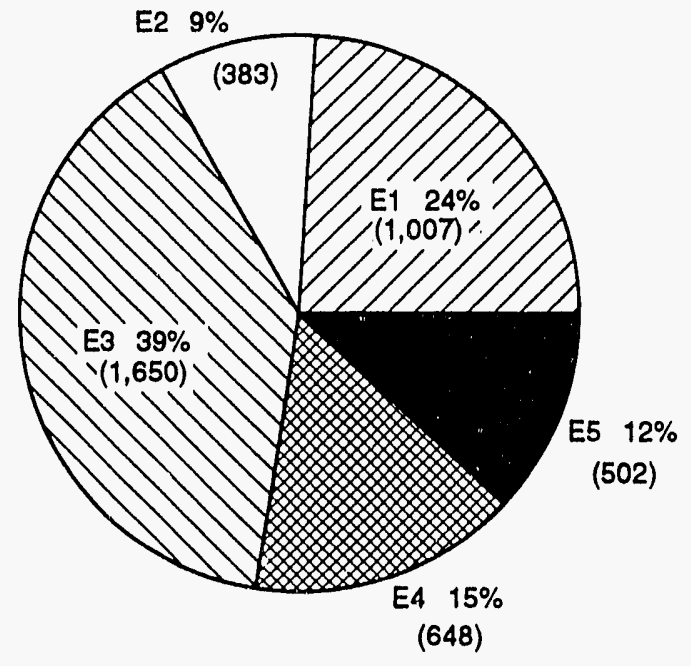

bnce.27.3Fimrapoo 
Because of the relatively small number of participants in 1988, the remainder of this chapter will present more detailed characteristics for the 1989 and 1990 participants only.

\subsection{PARTICIPANT CHARACTERISTICS}

Information on 1989 and 1990 participant characteristics was obtained directly from participant records 2 . The database of WRAP participant records contained information on participant owner/renter status and primary space heating fuel. ZIP Code information contained in this database was used to develop urban/rural specification. This information is presented in tables 3-1 through 3-4.

\begin{tabular}{|c|c|c|c|c|c|c|c|c|c|c|c|c|}
\hline \multicolumn{13}{|c|}{$\begin{array}{c}\text { TABLE 3-1 } \\
1989 \text { Participant Demographics }\end{array}$} \\
\hline \multirow{3}{*}{$\begin{array}{l}\text { Plan } \\
\text { E1 }\end{array}$} & \multicolumn{2}{|c|}{ Trolal } & \multicolumn{2}{|c|}{ Yroran. } & \multicolumn{2}{|c|}{ Ror $8 \%$} & \multicolumn{2}{|c|}{ oryine. } & \multicolumn{2}{|c|}{ Renter } & \multicolumn{2}{|c|}{ Tabie rompat } \\
\hline & 1,258 & $35 \%$ & 599 & $31 \%$ & 659 & $40 \%$ & 583 & $38 \%$ & 674 & $33 \%$ & & $6010 \mathrm{ng} / \mathrm{x}$ \\
\hline & $100 \%$ & & $48 \%$ & & $52 \%$ & & $46 \%$ & & $54 \%$ & & rov $\%$. & \\
\hline \multirow[t]{2}{*}{ E2 } & 242 & $7 \%$ & 132 & $7 \%$ & 110 & $7 \%$ & 184 & $12 \%$ & 58 & $3 \%$ & & o.tining. \\
\hline & $100 \%$ & & $55 \%$ & & $45 \%$ & & $76 \%$ & & $24 \%$ & & row 8 . & \\
\hline \multirow[t]{2}{*}{ E3 } & 1,640 & $46 \%$ & 1,012 & $52 \%$ & 628 & $38 \%$ & 538 & $35 \%$ & 1,093 & $53 \%$ & & coinnn $\%$ \\
\hline & $100 \%$ & & $62 \%$ & & $38 \%$ & & $33 \%$ & & $67 \%$ & & $101 \% \%$ & \\
\hline \multirow[t]{2}{*}{ E4 } & 253 & $7 \%$ & 124 & $6 \%$ & 129 & $8 \%$ & 102 & $7 \%$ & 151 & $7 \%$ & & odinini, \\
\hline & $100 \%$ & & $49 \%$ & & $51 \%$ & & $40 \%$ & & $60 \%$ & & $100 \% \%$ & \\
\hline \multirow[t]{2}{*}{ E5 } & 199 & $6 \%$ & 79 & $4 \%$ & 120 & $7 \%$ & 111 & $7 \%$ & 88 & $4 \%$ & & (4) \\
\hline & $100 \%$ & & $40 \%$ & & $60 \%$ & & $56 \%$ & & $44 \%$ & & $8 \% \%$ & \\
\hline \multirow[t]{2}{*}{ Total } & 3,592 & $100 \%$ & 1,946 & $100 \%$ & 1,646 & $100 \%$ & 1,518 & $100 \%$ & 2,064 & $100 \%$ & & colinn \% \\
\hline & $100 \%$ & & $54 \%$ & & $46 \%$ & & $42 \%$ & & $57 \%$ & & $100 \%$ & \\
\hline
\end{tabular}

2/ The participant tabulations presented in sections 3.2, 3.3, and 3.4 are based on data from the WRAPTRACK database. These numbers are slightly different from those reported by the WRAP Unit's monthly summary reports, which were used as the basis for section 3.1. The only significant difference occurs in plan E1. Many participants of plan E1 received measures under plan E2 as well; the WRAP Unit reports these participants under both plans, essentially "doublecounting," while the WRAPTRACK database (and this report) count them under plan E1 only. 


\begin{tabular}{|c|c|c|c|c|c|c|c|c|c|c|}
\hline \multicolumn{11}{|c|}{$\begin{array}{c}\text { TABLE 3-2 } \\
1990 \text { Participant Demographics }\end{array}$} \\
\hline \multirow{3}{*}{$\begin{array}{l}\text { P1 } \\
\text { E1 }\end{array}$} & \multicolumn{2}{|c|}{ rowa } & \multicolumn{2}{|c|}{ 4rian } & \multicolumn{2}{|c|}{ norol } & \multicolumn{2}{|c|}{ Sonier } & \multicolumn{2}{|c|}{ Renter. } \\
\hline & 713 & $19 \%$ & 370 & $18 \%$ & 343 & $20 \%$ & 314 & $21 \%$ & 399 & $17 \%$ \\
\hline & $100 \%$ & & $52 \%$ & & $48 \%$ & & $44 \%$ & & $56 \%$ & \\
\hline \multirow[t]{2}{*}{$\mathrm{E} 2$} & 383 & $10 \%$ & 245 & $12 \%$ & 138 & $8 \%$ & 240 & $16 \%$ & 143 & $6 \%$ \\
\hline & $100 \%$ & & $64 \%$ & & $36 \%$ & & $63 \%$ & & $37 \%$ & \\
\hline \multirow[t]{2}{*}{ E3 } & 1,633 & $43 \%$ & 882 & $42 \%$ & 751 & $43 \%$ & 464 & $32 \%$ & 1,169 & $50 \%$ \\
\hline & $100 \%$ & & $54 \%$ & & $46 \%$ & & $28 \%$ & & $72 \%$ & \\
\hline \multirow[t]{2}{*}{$\mathrm{E} 4$} & 582 & $15 \%$ & 282 & $14 \%$ & 300 & $17 \%$ & 182 & $12 \%$ & 400 & $17 \%$ \\
\hline & $100 \%$ & & $48 \%$ & & $52 \%$ & & $31 \%$ & & $69 \%$ & \\
\hline \multirow[t]{2}{*}{ E5 } & 507 & $13 \%$ & 298 & $14 \%$ & 209 & $12 \%$ & 268 & $18 \%$ & 239 & $10 \%$ \\
\hline & $100 \%$ & & $59 \%$ & & $41 \%$ & & $53 \%$ & & $47 \%$ & \\
\hline \multirow[t]{2}{*}{ Total } & 3,818 & $100 \%$ & 2,077 & $100 \%$ & 1,741 & $100 \%$ & 1,468 & $100 \%$ & 2,350 & 100 \\
\hline & $100 \%$ & & $54 \%$ & & $46 \%$ & & $38 \%$ & & $62 \%$ & \\
\hline
\end{tabular}

Historically, roughly half of WRAP's participants were urban and half were rural, indicating that the WRAP program was successful in reaching rural clients as well as urban. The only significant shift in this pattern occurred within plan E5, which was 60 percent rural in 1989 and 60 percent urban in 1990. The number of owner and renter participants was also roughly equal, with slightly higher renter participation than owner. A higher number of renters was particularly evident in plans E3 and E4, while E2 was the only plan that served more owners than renters. This is due to state regulations affecting plan E2, which specify that furnace replacement, one of the three major retrofits available under this plan, can only be done in owner occupied, 1-3 unit housing. 


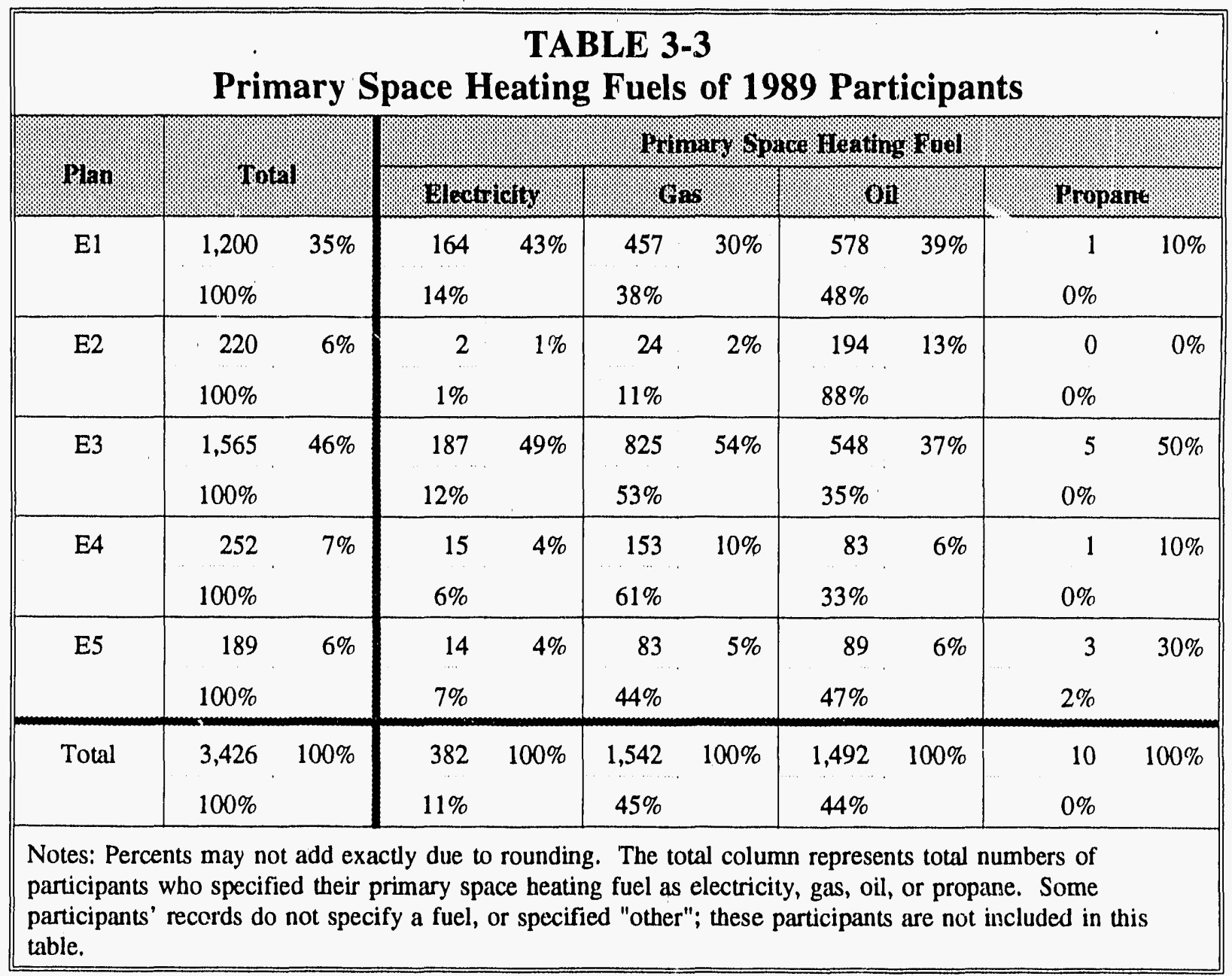

The tabulation of participants by primary space heating fuel (tables 3-3 and 3-4) show that almost all WRAP participants use gas or oil as their primary space heating fuel, with oil accounting for over 60 percent of participants in 1990. However, there were some significant differences in fuel-type shares for different plans. As expected, plan E2, which targets oil heating customers, was predominantly used by oil-heating participants. Plan E4, which targets payment-troubled customers, had a disproportionately high number of gas-heating participants. While these patterns have been consistent from 1989 to 1990 , there have been several major shifts in plan participation by fuel type. As discussed in section 3.1, the general trend in participation from 1989 to 1990 was towards the more intensive plans E4 and E5, as these plans gathered momentum. Participation by electric space heating customers, however, remained disproportionately low in plans E4 and E5, although there was a substantial shift from plan E1 to plan E3. 


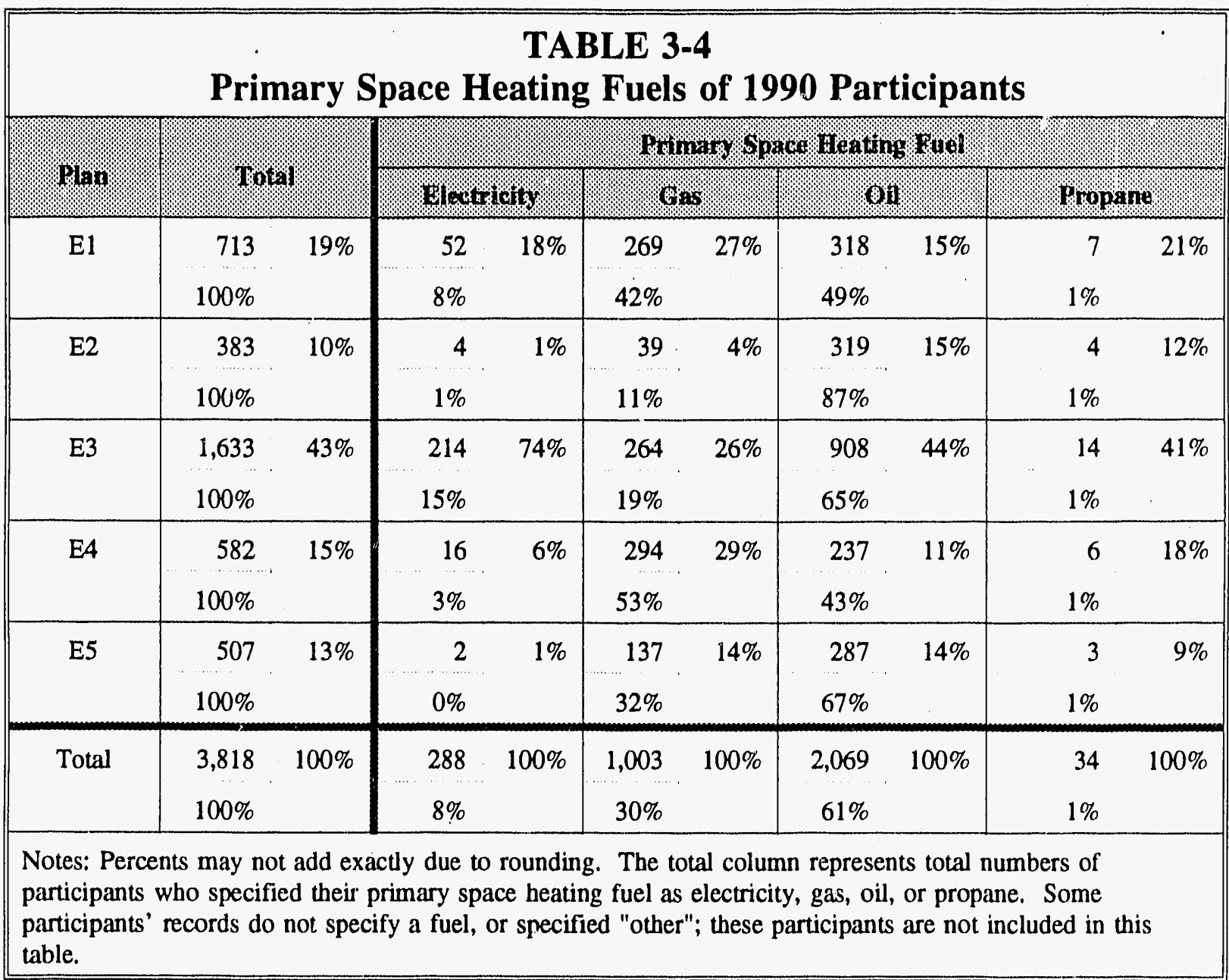

An independent survey of 1988 and 1989 WRAP participants, conducted in early 1990, confirmed these urban/rural, owner/renter, and fuel type characteristics indicated by the database analysis above, and provided other information on participant characteristics as well $\frac{31}{2}$. The survey indicated that approximately two-thirds of 1989 WRAP participants had lived in the same household for six or more years. The structures were most often (fifty-five percent) single family, and only eight percent contained five or more units (twenty percent of renters lived in buildings with five or more units). The median age of the structures treated by WRAP was forty-three years; owner-occupied structures were newer on average than renter-occupied structures. There was at least one elderly person in just over one-third of the households, and in nearly half (forty-seven percent) of the participant-owned households.

3/ See the accompanying report, Process Evaluation, Weatherization Residential Assistance Partnership (WRAP Program), Technical Development Corporation, prepared for Northeast Utilities, October 1990. The customer survey form and the results of the survey are contained in Appendix $G$ of this report. 
Over half of the surveyed participants had been served by one of three CAAs: New Opportunities for Waterbury (NOW), Thames Valley Council for Community Action (TVCCA), and Windham Area Community Action Program (WACAP).

\subsection{MEASURES INSTALLED}

The selection of measures to be installed for each participant was based primarily on the needs of each individual household $\stackrel{1}{-}$. Although the choice of measures was limited by the plan of participation and by the expenditure ceiling under that plan $2 /$, households in critical need of extensive measures were often moved to a plan which qualified them to receive such measures.3/. Therefore, the frequency of installation of different measures should roughly indicate the weatherization needs among program participants. This section highlights overall patterns of measure installation, commonly installed measures under each plan, and differences in measure installations between urban and rural participants as well as between owner and renter participants; for udditional reference, a full set of measure installation data is included in Appendix B.

Figures 3-5 and 3-6 show the number of WRAP participants who received each measure in 1989 and 1990. The most commonly installed measures were relatively low-cost items with broad availability across plans. Most frequently installed were infiltration measures such as caulking, weatherstripping, and door sweeps, and water heating measures such as water heater wraps and low-flow faucet aerators and showerheads. Most measures were received by less than ten percent of participants, indicating that the program's high degree of flexibility allowed for the tailoring of measure selection to the individual needs of the household.

The survey of selected WRAP participants, discussed in the last section, asked recipients what measures they received, and their answers were somewhat different than what participant records show. The top five most commonly received measures, as reported by participants, are shown in table 3-5. Some of the differences may come from the fact that these measures, with the exception of light bulbs, may have been provided and paid for through WAP for some E1 and E2 customers, and thus were not recorded by the installing CAA as WRAP measures. Also, participants may have been more likely to remember and report larger, more expensive measures such as storm windows $\stackrel{41}{ }$, rather than more minor measures such

1' The choice of appropriate measures for each individual participant was made by the auditor, and based on an assessment of needs of the household and a general prioritization by the audit. Because of resource constraints, selected measures were prioritized based on utility guidelines. For additional reference, Appendix $G$ includes sample audit forms.

2/ See chapter 1 for a full discussion of plan-by-plan measure availability and spending limits.

3/ The most common example of this was plan E3 participants being moved to plan E5; however, there were other cases of CAA-recruited individuals being shifted to the more intensive "utilityrecruited" plans (see chapter 2).

4/ Storm windows installed under WRAP were recorded as window treatments under measure twenty-eight. Window treatments were the fifteenth most commonly installed measure, according to WRAP records. 


\section{FIGURE 3-4}

\section{Measures Received by 1989 WRAP Participants}

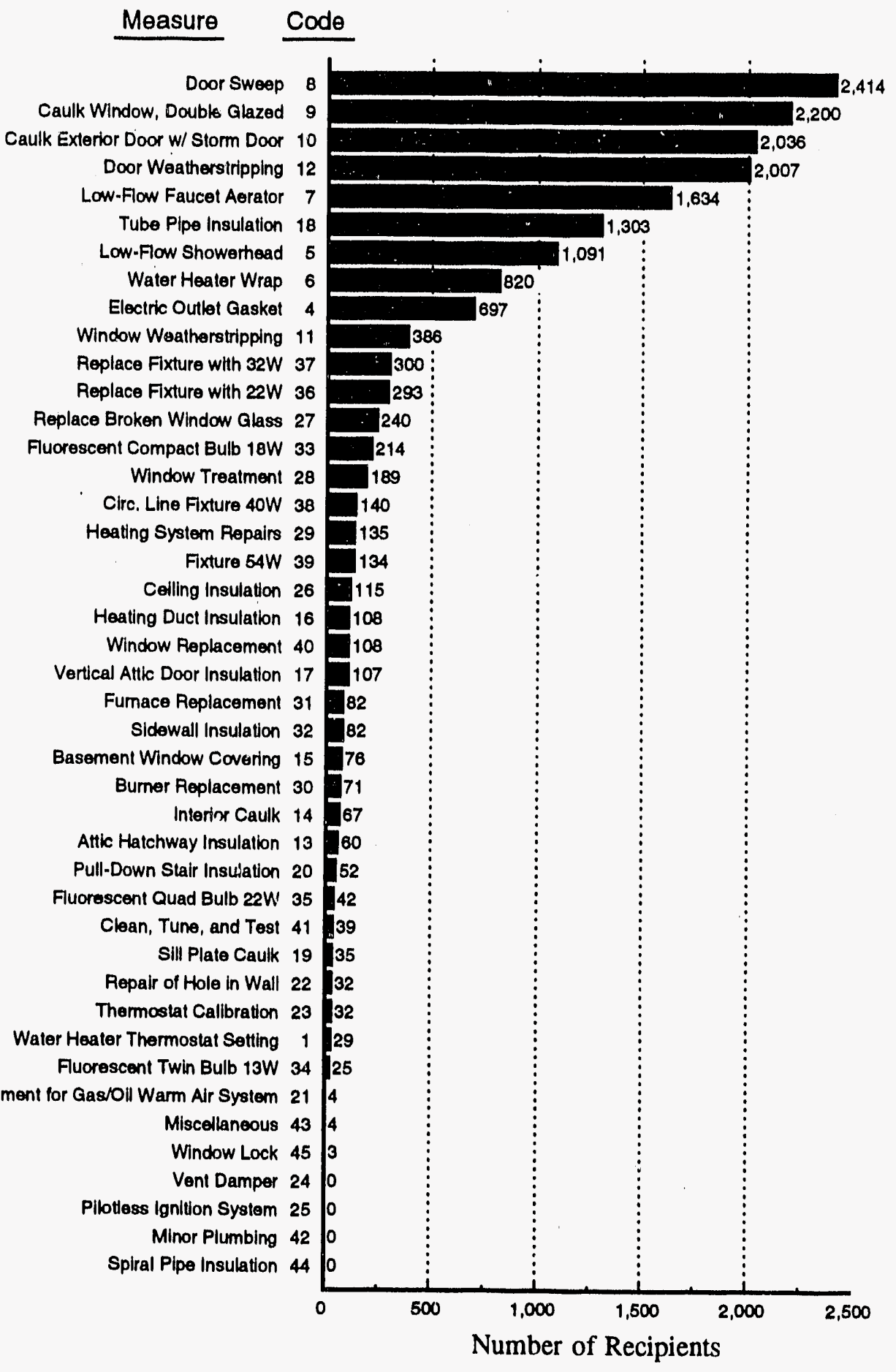

(Total number of participants in $1989=3,592$ ) 


\section{Measures Received by 1990 WRAP Participants}

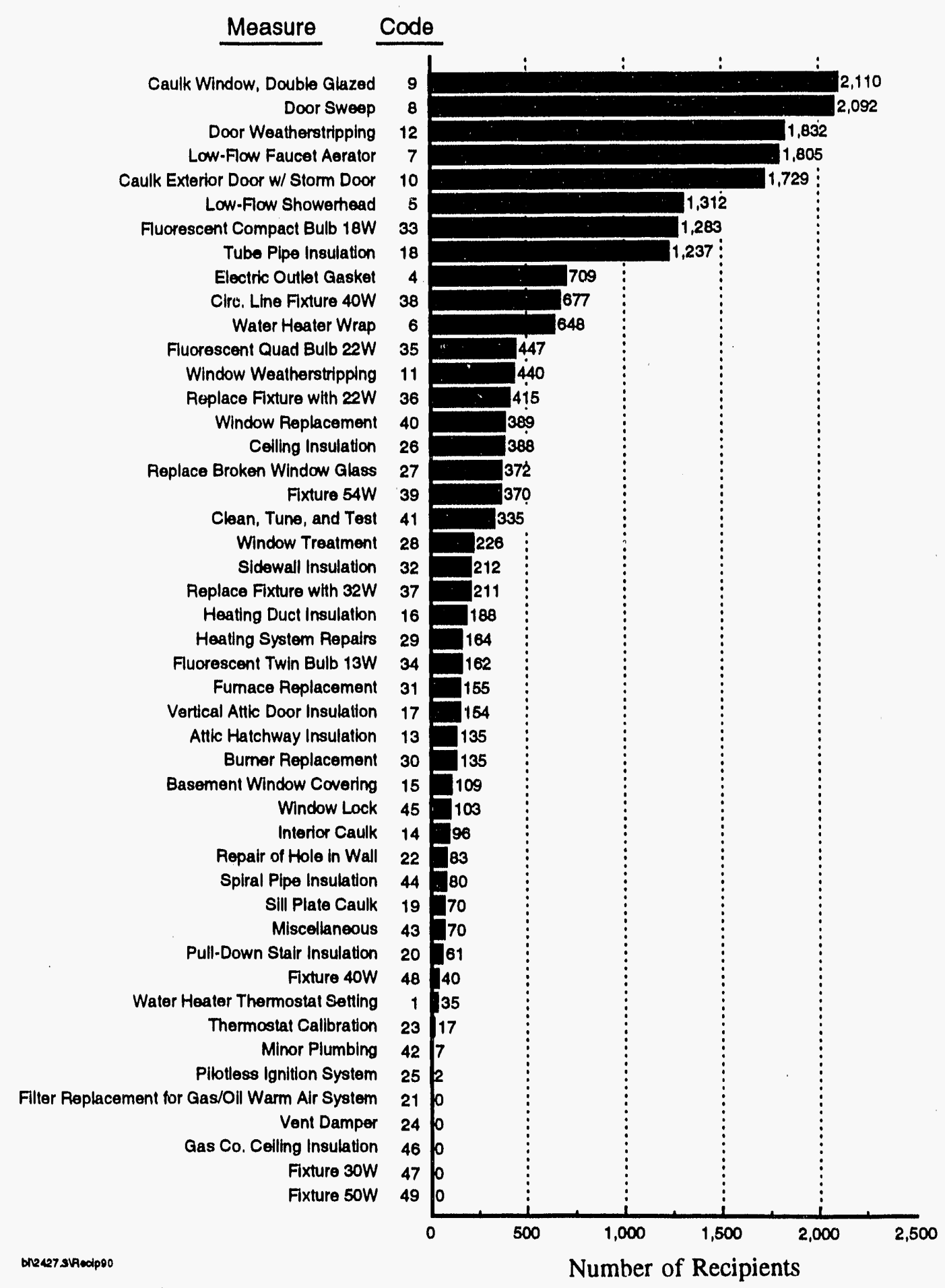

(Total number of participants in $1990=3,818$ ) 


\begin{tabular}{|c|c|}
\hline \multicolumn{2}{|c|}{$\begin{array}{c}\text { TABLE } 3-5 \\
\text { Measures Received Under WRAP }\end{array}$} \\
\hline 14arsire & Percent of Respondents Who Rereived \\
\hline Weatherstripping & $88 \%$ \\
\hline Water Heater Wraps & $53 \%$ \\
\hline Low Flow Showerheads/Faucets & $48 \%$ \\
\hline Storm Windows & $41 \%$ \\
\hline Efficient Light Bulbs & $37 \%$ \\
\hline
\end{tabular}

as caulking. Respondents may also have grouped caulking with weatherstripping. WRAP recorded the installation of efficient light bulbs under three different measures (measure numbers thirty-three through thirty-five), and none of these individual measures ranked in the top ten; however, the installation of energy-efficient lighting fixtures (measures thirty-six through thirty-nine), which included the installation of appropriate bulbs, may have been included in this category by the survey respondents. If all the lighting measures were treated in aggregate, the installation of energy-efficient light bulbs may well have been one of the five most commonly installed measures.

On a plan-by-plan basis, the five most commonly installed measures in 1989 and 1990 were the most common under plans E1 and E2. Caulking (door and window) and door sweeps were among the top five for every plan in both years. Tube pipe insulation was very common under the more intensive plans E2, E4, and E5, in both years. In 1989, window treatments and heating repairs were in the top five for plans E5 and E2, respectively. In 1990, two new measures (window replacement and heating system clean/tune/test) ranked in the top five for individual plans (E4 and E2, respectively).

The most significant changes in measure selection from 1989 to 1990 involved lighting measures, most of which were received by many more participants. Fluorescent bulb installation measures in particular were installed much more frequently.

Among 1989 participants, measure installation patterns showed some interesting differences between urban and rural participants. The top five most commonly installed measures shown in figure 3-4 were all received by a much higher percentage of rural participants than urban participants, indicating that rural participants were more likely to need those measures. However, lighting measures involving fixture replacement (numbers thirty-six through thirty-nine) were installed exclusively in urban residences.

Many measures which were installed just as commonly in urban homes as in rural homes in 1989 showed an interesting difference in the average number of installations per recipient, possibly indicating differences in how severe the need was among the households with a need for that measure. Analysis showed that for almost every measure that showed a difference between urban and rural, it was the urban participants with a higher number of installations per participant. However, this may be driven by buildings with five or more units; each such building is treated for accounting purposes as one participant, and such buildings are presumably more common in urban areas of the service territory. Only one measure, sidewall insulation (number thirty-two), showed a more extensive need among rural recipients 
than among urban recipients; this may be explained by a larger average size of rural homes, and a greater predominance of single-family homes that have wore wall exposed to the elements. A plan-by-plan statistical analysis of average number of installations per urban and rural participant is included in Appendix B.

There were also some differences between the percents of owners and renters who received certain measures in 1989. Almost twice as many owners (forty-four percent to twenty-four percent) received pipe insulation, while the lighting fixture measures were installed exclusively in rental homes.

In terms of number of installations per recipient in 1989, owner recipients received, on average, more electric outlet gaskets, pipe insulation, and burner replacements than did rural recipients. Renter recipients on average received more heating duct insulation, sill plate caulk, repair of holes in walls, and sidewall insulation than did owners.

\subsection{EXPENDITURES PER PARTICIPANT}

The average level of expenditures per participant (see tables 3-6 and 3-7) did not vary greatly between urban and rural participants, or between owners and renters. However, there were interesting differences in plan E4 and E5 expenditures between different primary space heating fuel types. As discussed in chapter 1, plans E4 and E5 are relatively intensive plans with high limits on expenditures per participant. WRAP records show that oil and gas heating participants of these plans received a higher average weatherization investment than did electric or propane heat users.

Average investment per participant almost doubled from 1989 to 1990 . The increase was particularly evident in plan E4, which targets high arrearage customers. This may indicate that as plan E4 gathered momentum and attracted more participants, the weatherization needs of these customers were revealed to be much greater than anticipated. This increase in expenditures per participant, along with the general increase in participation and shift towards the more intensive plans, contributed to the large budget overruns of 1990. 


\begin{tabular}{|c|c|c|c|c|c|}
\hline \multicolumn{6}{|c|}{$\begin{array}{l}\text { TABLE 3-6 } \\
\text { WRAP Expenditures per } 1989 \text { Participant }\end{array}$} \\
\hline Plan & 4ycrage & Groan. & niral & Oroner. & Renter \\
\hline E1 & $\$ 113$ & $\$ 108$ & $\$ 118$ & $\$ 122$ & $\$ 106$ \\
\hline E2 & 510 & 513 & 505 & 518 & 483 \\
\hline E3 & 150 & 142 & 163 & 187 & 132 \\
\hline $\mathrm{E} 4$ & 655 & 648 & 663 & 599 & 694 \\
\hline E5 & 1,290 & 1,328 & 1,265 & 1,299 & 1,279 \\
\hline Total & $\$ 260$ & $\$ 237$ & $\$ 287$ & $\$ 311$ & $\$ 223$ \\
\hline \multicolumn{6}{|c|}{ Note: Units are nominal dollars. } \\
\hline \multirow{2}{*}{ Plan. } & \multirow{2}{*}{4 rerage. } & \multicolumn{4}{|c|}{ Primary Space Heating ruel: } \\
\hline & & miectrigst: & Q9as. & oil. & Yropane \\
\hline E1 & $\$ 113$ & $\$ 73$ & $\$ 117$ & $\$ 122$ & $\$ 126$ \\
\hline $\mathrm{E} 2$ & 510 & 578 & 608 & 498 & N/A \\
\hline E3 & 150 & 148 & 130 & 178 & 249 \\
\hline E4 & 655 & 490 & 646 & 715 & 99 \\
\hline E5 & 1,290 & 953 & 1,133 & 1,422 & 1,028 \\
\hline Total & $\$ 260$ & $\$ 161$ & $\$ 239$ & $\$ 302$ & $\$ 456$ \\
\hline
\end{tabular}




\begin{tabular}{|c|c|c|c|c|c|}
\hline \multicolumn{6}{|c|}{$\begin{array}{l}\text { TABLE 3-7 } \\
\text { WRAP Expenditures per } 1990 \text { Participant }\end{array}$} \\
\hline Pian: & ficrage & Groan & Rorral & Orroer. & Renter. \\
\hline E1 & $\$ 135$ & $\$ 133$ & $\$ 137$ & $\$ 142$ & $\$ 130$ \\
\hline $\mathrm{E} 2$ & 453 & 462 & 436 & 473 & 419 \\
\hline E3 & 194 & 191 & 198 & 241 & 176 \\
\hline $\mathrm{E} 4$ & 1,123 & 1,159 & 1,089 & 1,286 & 1,048 \\
\hline E5 & 1,334 & 1,348 & 1,315 & 1,559 & 1,083 \\
\hline Total & $\$ 502$ & $\$ 510$ & $\$ 492$ & $\$ 628$ & $\$ 424$ \\
\hline \multicolumn{6}{|c|}{ Note: Units are nominal dollars. } \\
\hline \multirow{2}{*}{ PIIn? } & \multirow{2}{*}{ 4. } & \multicolumn{4}{|c|}{ Primary space Irating fulel. } \\
\hline & & Mecticis: & - & 1.11:- & rropane \\
\hline $\mathrm{E} 1$ & $\$ 135$ & $\$ 96$ & $\$ 127$ & $\$ 148$ & $\$ 119$ \\
\hline $\mathrm{E} 2$ & 453 & 637 & 523 & 439 & 423 \\
\hline E3 & 194 & 180 & 211 & 206 & 191 \\
\hline $\mathrm{E} 4$ & 1,123 & 933 & 1,031 & 1,314 & 1,169 \\
\hline E5 & 1,334 & 625 & 1,274 & 1,523 & 1,204 \\
\hline Total & $\$ 502$ & $\$ 216$ & $\$ 586$ & $\$ 543$ & $\$ 465$ \\
\hline \multicolumn{6}{|c|}{ Note: Units are nominal dollars. } \\
\hline
\end{tabular}




\section{CHAPTER 4 \\ IMPACT EVALUATION}

A weatherization program impact evaluation determines what savings and arrearage reductions were achieved. This chapter begins with a discussion of the different ways of determining savings, and of the types of data that are available for an evaluation of WRAP's impacts. Section 4.2 presents estimates of total first year electricity savings, based on customer billing data. Section 4.3 follows with first year electricity savings based on engineering estimates. Section 4.4 contains total lifetime electricity savings, based on engineering estimates. Section 4.5 presents the "big picture" of WRAP's savings, for gas, oil, propane, and electricity. Section 4.6 examines the billing analysis results (presented in 4.2 ) in terms of savings per participant; this section reveals who benefitted the most, on average, from participation in the WRAP program. The next section examines the cost-effectiveness of the WRAP program based on several different approaches. Comparisons are made by fuel type, urban/rural location, and the owner/renter status of the participant. The final section of the chapter (4.8) summarizes WRAP's impact on participants' electric utility arrearages.

\subsection{DESCRIPTION OF DATA}

There are two widely used and accepted methods of determining the savings that result from a weatherization program. One method is to make engineering estimates of savings, based on the theoretical energy-saving potential of the measures that were installed. Savings estimates calculated in this way are known as "engineering estimates." A second method is to estimate savings based on the actual measured consumption of the participant households, as contained in monthly billing records. Savings calculated from billing records are referred to as "actual savings"; even though they are estimates, they are closer to reality than the engineering estimates, and are based on actual data (monthly consumption) rather than theory.

There are two main approaches of estimating actual savings from billing records. The first is to compare the post-installation consumption of participants to the consumption of a control group during the same time period. Under this method, the participant and the control group should have similar attributes, including demographic and housing characteristics. The other method of estimating actual savings is to compare post-installation consumption of the participants to their pre-installation consumption. Because weather conditions vary from year to year and affect consumption, this approach requires that the consumption data be weather-normalized. There are several computer models available commercially that are designed to weather-normalize residential energy consumption data. Most require at least a full year of pre-installation data as well as a full year of post-installation data in order to generate accurate results.

The impact evaluation for the WRAP program includes both engineering estimates ${ }^{1}$ and actual savings. Actual savings were estimated using billing data of participants before and after weatherization. Weather-normalization was achieved through the Princeton Scorekeeping Method (PRISM) model; a more detailed description of the model is included in Appendix D.

1 For a full summary of the engineering estimates of savings from each measure available under the WRAP program, see Appendix C. 
A key difference between engineering estimates and actual savings is that engineering estimates can be developed for both the first year after installation and the lifetime of the measures that were installed. Actual savings are first-year only. A complete impact evaluation should include both types of estimates, because lifetime savings are more appropriate when evaluating the long-term bene fits and costeffectiveness of a program, and actual savings estimates are valuable because they can be compared to the first-year engineering estimates to determine how closely reality has matched the predictions of theory.

Finally, engineering estimates can be developed for any of the primary fuel types (electricity, gas, oil, and propane). Savings can then be converted to Btus for comparisons between the various fuel types, and summed for an cyerview of total energy savings. Estimates of actual savings require billing records from each of the relevant utilities; electricity billing records only allow for calculation of electricity savings. The actual savings included in this report are for electricity only.

The remainder of this chapter presents data for 1989 and 1990 WRAP participants only. As discussed in chapter 3, the WRAP program did not begin installations until the fall of 1988, so there were relatively few installations in that year. In addition, several of the more intensive WRAP plans did not begin to attract significant numbers of participants until 1990, so savings estimates from 1988 are not indicative of the performance of the WRAP program as a whole. Information on the savings from 1988 iristallations is included in Appendices B, C, and D.

\subsection{FIRST YEAR ELECTRICITY SAVINGS BASED ON BILLING DATA}

The billing records of 1989 WRAP participants indicate a net increase in consumption subsequent to participation in the WRAP program of $954 \mathrm{MWh}$ for the first year of measurement (in comparison with their average annual usage prior to installation - see table 4-1). However, the increased consumption are overwhelmingly the result of increases within the rural and renter categories for plan E3. Plan E1 also indicates an increase in energy consumption of $13 \mathrm{MWh}$ for the first year analysis. Plans E1 and E3 consisted of the installation of low cost infiltration and water heating measures. Therefore, it may be indicated by the analytical results that these plans initially lacked comprehensiveness or behavioral influence such that the program participants experienced no electricity savings. However, a relatively small percentage of WRAP participants used electricity for space and water heating. In addition, there is no way to measure the avoidance of the use of electric space heaters when burners or furnaces break down. This usage is avoided when burners and furnaces are repaired or replaced. Thirdly, electric customers with extremely high energy usage (and thus probably higher weatherization energy savings potential) are referred to the Spectrum Program, and do not participate in WRAP. The remaining plans, particularly plan E4, indicate energy savings (59 MWh for E2, 1,137 MWh for E4, and $29 \mathrm{MWh}$ for E5). These plans are, by design, much more comprehensive in nature than plans E1 and E3. 


\begin{tabular}{|c|c|c|c|c|c|c|c|c|c|c|}
\hline \multicolumn{11}{|c|}{$\begin{array}{c}\text { TABLE 4-1 } \\
\text { First Year Electricity Savings Based or } \\
1989 \text { Participants } \\
\text { (MWh) }\end{array}$} \\
\hline (1) & \multicolumn{2}{|c|}{ 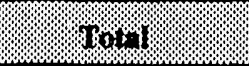 } & \multicolumn{2}{|c|}{ 8rinin } & \multicolumn{2}{|c|}{$R_{10} \cdot 1}$. & \multicolumn{2}{|c|}{9 river. } & \multicolumn{2}{|c|}{ rentror } \\
\hline \multirow[t]{2}{*}{ E1 } & -13.0 & $1 \%$ & $\begin{array}{r}-17.3 \\
-17 .\end{array}$ & $-2 \%$ & 4.3 & $0 \%$ & 36.0 & $4 \%$ & $\begin{array}{r}-56.1 \\
.\end{array}$ & $2 \%$ \\
\hline & $100 \%$ & & $133 \%$ & & $-33 \%$ & & $-277 \%$ & & $432 \%$ & \\
\hline \multirow[t]{2}{*}{ E2 } & 59.0 & $-6 \%$ & 25.6 & $3 \%$ & 33.4 & $-2 \%$ & 57.6 & $6 \%$ & 2.0 & $0 \%$ \\
\hline & $100 \%$ & & $43 \%$ & & $57 \%$ & & $98 \%$ & & $3 \%$ & \\
\hline \multirow[t]{2}{*}{ E3 } & $\begin{array}{r}-2,165.3 \\
.\end{array}$ & $227 \%$ & 804.7 & $80 \%$ & $-2,970.0$ & $152 \%$ & 801.8 & $81 \%$ & $-2,718.5$ & $115 \%$ \\
\hline & $100 \%$ & & $-37 \%$ & & $137 \%$ & & $-37 \%$ & & $126 \%$ & \\
\hline \multirow[t]{2}{*}{ E4 } & $1,136.6$ & $-119 \%$ & 171.5 & $17 \%$ & 965.1 & $-49 \%$ & 198.2 & $20 \%$ & 162.0 & $-7 \%$ \\
\hline & $100 \%$ & & $15 \%$ & & $85 \%$ & & $17 \%$ & & $14 \%$ & \\
\hline \multirow[t]{2}{*}{ E5 } & 29.0 & $-3 \%$ & 21.0 & $2 \%$ & 8.0 & $0 \%$ & -98.7 & $-10 \%$ & 133.6 & $-6 \%$ \\
\hline & $100 \%$ & & $72 \%$ & & $28 \%$ & & $-340 \%$ & & $461 \%$ & \\
\hline \multirow[t]{2}{*}{ Total } & -953.7 & $100 \%$ & $1,005.5$ & $100 \%$ & $-1,959.2$ & $100 \%$ & 994.9 & $100 \%$ & $-2,364.8$ & $100 \%$ \\
\hline & $100 \%$ & & $-105 \%$ & & $205 \%$ & & $-104 \%$ & & $248 \%$ & \\
\hline
\end{tabular}

Reviewing the results of the analysis of electricity savings by primary space heating fuel type (table 4-2) shows participants with electric space heat not only saved in their first year consumption, but produced the largest savings of all fuel types $(560 \mathrm{MWh})$. Almost all electricity savings were found in plan E3. This may indicate that the low cost infiltration and water heating measures installed were primarily designed to affect mainly the electric end-uses, or that the primary electric space heated dwellings were in especially critical condition relative to infiltration. All other primary fuel types indicated a net increase in energy consumption for the one year period after installation of the WRAP measures. Thesi results seem to favor the assumption that the 1989 program, for plan E3, were more applicable to the electric heat participants than for the other heating fuels. 


\begin{tabular}{|c|c|c|c|c|c|c|c|c|c|c|}
\hline \multicolumn{11}{|c|}{$\begin{array}{c}\text { TABLE 4-2 } \\
\text { First Year Electricity Savings Based on Billing Data } \\
1989 \text { Participants } \\
\text { (MWh) }\end{array}$} \\
\hline \multirow{2}{*}{ 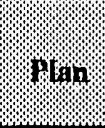 } & \multirow{2}{*}{\multicolumn{2}{|c|}{$8 \%$}} & \multicolumn{8}{|c|}{ 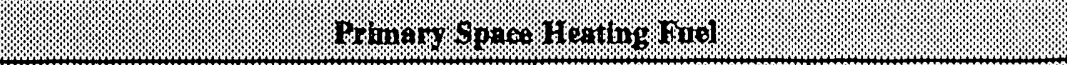 } \\
\hline & & & \multicolumn{2}{|c|}{ 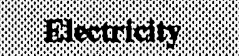 } & \multicolumn{2}{|c|}{ 8) } & \multicolumn{2}{|c|}{01} & \multicolumn{2}{|c|}{ Propnin } \\
\hline \multirow[t]{2}{*}{ E1 } & 20.9 & \multirow[t]{2}{*}{$-1 \%$} & -27.8 & \multirow[t]{2}{*}{$-5 \%$} & -89.3 & \multirow[t]{2}{*}{$4 \%$} & 138.0 & \multirow[t]{2}{*}{$-663 \%$} & 0 & \multirow[t]{2}{*}{$0 \%$} \\
\hline & $100 \%$ & & $-133 \%$ & & $-427 \%$ & & $660 \%$ & & $0 \%$ & \\
\hline \multirow[t]{2}{*}{ E2 } & 52.8 & \multirow[t]{2}{*}{$-3 \%$} & \multirow[t]{2}{*}{ N/A } & & $\begin{array}{c}9.3 \\
2.1 .1 . . .\end{array}$ & \multirow[t]{2}{*}{$0 \%$} & $\begin{array}{c}43.5 \\
\ldots \ldots \ldots \ldots \ldots . . .\end{array}$ & \multirow[t]{2}{*}{$-209 \%$} & N/A & \\
\hline & $100 \%$ & & & & $18 \%$ & & $82 \%$ & & & \\
\hline \multirow[t]{2}{*}{ E3 } & $-2,065.1$ & \multirow[t]{2}{*}{$128 \%$} & 506.6 & \multirow[t]{2}{*}{$90 \%$} & $-2,452.4$ & \multirow[t]{2}{*}{$115 \%$} & -103.5 & \multirow[t]{2}{*}{$498 \%$} & -15.8 & \multirow[t]{2}{*}{$131 \%$} \\
\hline & $100 \%$ & & $-25 \%$ & & $119 \%$ & & $5 \%$ & & $1 \%$ & \\
\hline $\mathrm{E} 4$ & 368.1 & $.23 \%$ & 33.0 & $6 \%$ & 309.1 & $-14 \%$ & 26.0 & $-125 \%$ & -.2 & $2 \%$ \\
\hline & $100 \%$ & & $9 \%$ & & $84 \%$ & & $7 \%$ & & $0 \%$ & \\
\hline E5 & 13.3 & $-1 \%$ & 48.3 & $9 \%$ & $\begin{array}{c}85.9 \\
0 \ldots\end{array}$ & $-4 \%$ & -124.8 & $600 \%$ & 3.9 & $-32 \%$ \\
\hline & $100 \%$ & & $363 \%$ & & $646 \%$ & & $-938 \%$ & & $29 \%$ & \\
\hline Total & $-1,609.8$ & $100 \%$ & 560.1 & $100 \%$ & $-2,137.4$ & $100 \%$ & -20.8 & $100 \%$ & -12.1 & $100 \%$ \\
\hline & $100 \%$ & & $-35 \%$ & & $133 \%$ & & $1 \%$ & & $1 \%$ & \\
\hline $\begin{array}{l}\text { Notes: } \\
\text { particip } \\
\text { not spe }\end{array}$ & tages and & $\begin{array}{l}\text { nbers } \\
\text { heirs } \\
\text { fy "ot }\end{array}$ & $\begin{array}{l}\text { not add } \\
\text { heating } \\
\text { savings }\end{array}$ & $\begin{array}{l}\text { actly } \\
\text { as e } \\
m \text { the }\end{array}$ & $\begin{array}{l}\text { to roundin } \\
\text { tricity, gas, } \\
\text { participants }\end{array}$ & $\begin{array}{l}\text { The to } \\
\text { d, or pro } \\
\text { re not in }\end{array}$ & $\begin{array}{l}1 \text { column re } \\
\text { bane. Some } \\
\text { luded in thi }\end{array}$ & $\begin{array}{l}\text { presents } \\
\text { particip } \\
\text { s table. }\end{array}$ & $\begin{array}{l}\text { tal savin } \\
\text { ts' recor }\end{array}$ & $\begin{array}{l}\text { from } \\
\text { do }\end{array}$ \\
\hline
\end{tabular}

The analysis of the billing records of 1990 participants shows overall first year electricity savings of 1,052 MWh (table 4-3). These savings primarily resulted from plan E3, particularly for urban and renter participants. It may be that the 1990 program focused on the urban and renter communities to increase program participation and resulted in a more comprehensive treatment of these dwellings. The WRAP Program also placed a higher priority on electricity-saving measures in 1990 than in 1989.

A review of each plan individually indicated that all resulted in net first year energy savings. However, assessing individual components of the plans showed that the rural participants in plans E2 and E3 produced no savings, having increased their first year annual energy consumption by $22 \mathrm{MWh}$ (rural E2) and $171 \mathrm{MWh}$ (rural E3). 


\begin{tabular}{|c|c|c|c|c|c|c|c|c|c|c|}
\hline \multicolumn{11}{|c|}{$\begin{array}{c}\text { TABLE } 4-3 \\
\text { First Year Electricity Savings Based on Billing Data } \\
1990 \text { Participants } \\
\text { (MWh) }\end{array}$} \\
\hline ryin & \multicolumn{2}{|c|}{ 18, } & \multicolumn{2}{|c|}{ 146, } & \multicolumn{2}{|c|}{$\mathrm{n}_{14} 4$} & \multicolumn{2}{|c|}{ 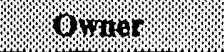 } & \multicolumn{2}{|c|}{ Yonitor } \\
\hline \multirow[t]{2}{*}{ E1 } & 131.6 & $13 \%$ & 23.3 & $3 \%$ & 108.3 & $88 \%$ & 75.2 & $28 \%$ & 51.2 & $4 \%$ \\
\hline & $100 \%$ & & $18 \%$ & & $82 \%$ & & $57 \%$ & & $39 \%$ & \\
\hline \multirow[t]{2}{*}{ E2 } & 16.8 & $2 \%$ & 38.5 & $4 \%$ & -21.7 & $-16 \%$ & 97.2 & $36 \%$ & -52.1 & $-4 \%$ \\
\hline & $100 \%$ & & $229 \%$ & & $-129 \%$ & & $579 \%$ & & $-310 \%$ & \\
\hline \multirow[t]{2}{*}{ E3 } & 718.8 & $68 \%$ & 889.7 & $96 \%$ & -170.9 & $-129 \%$ & -29.9 & $-11 \%$ & $1,131.9$ & $97 \%$ \\
\hline & $100 \%$ & & $124 \%$ & & $-24 \%$ & & $-4 \%$ & & $157 \%$ & \\
\hline \multirow[t]{2}{*}{ E4 } & 147.0 & $14 \%$ & 8.3 & $1 \%$ & 138.7 & $105 \%$ & 84.8 & $32 \%$ & 43.5 & $4 \%$ \\
\hline & $100 \%$ & & $6 \%$ & & $94 \%$ & & $58 \%$ & & $30 \%$ & \\
\hline \multirow[t]{2}{*}{ E5 } & 37.4 & $4 \%$ & -31.4 & $-3 \%$ & $\begin{array}{r}68.8 \\
\ldots \ldots \ldots\end{array}$ & $52 \%$ & 39.8 & $15 \%$ & -4.9 & $0 \%$ \\
\hline & $100 \%$ & & $-84 \%$ & & $184 \%$ & & $106 \%$ & & $-13 \%$ & \\
\hline \multirow[t]{2}{*}{ Total } & $1,051.6$ & $100 \%$ & $\begin{array}{c}928.4 \\
\ldots \ldots \ldots .1 .\end{array}$ & $100 \%$ & 123.2 & $100 \%$ & $\begin{array}{c}267.1 \\
\ldots \ldots \ldots \ldots\end{array}$ & $100 \%$ & $1,169.6$ & $100 \%$ \\
\hline & $100 \%$ & & $88 \%$ & & $12 \%$ & & $25 \%$ & & $111 \%$ & \\
\hline
\end{tabular}

The cross-tabulation by primary space heating fuel type (table 4-4) shows over seventy percent of the electricity savings came from participants with gas space heating, producing energy savings of 706 $\mathrm{MWh}$. This result was largely attributable to plan E3 (764 MWh). It may be indicated here that as the program matured into 1990 , a greater emphasis was placed on diversity of participation.

Electric space heating participants accounted for eleven percent of the overall electricity savings, for a first year savings of $107 \mathrm{MWh}$. All fuels resulted in net energy savings except for the propane participants who increased their consumption by $10 \mathrm{MWh}$. 


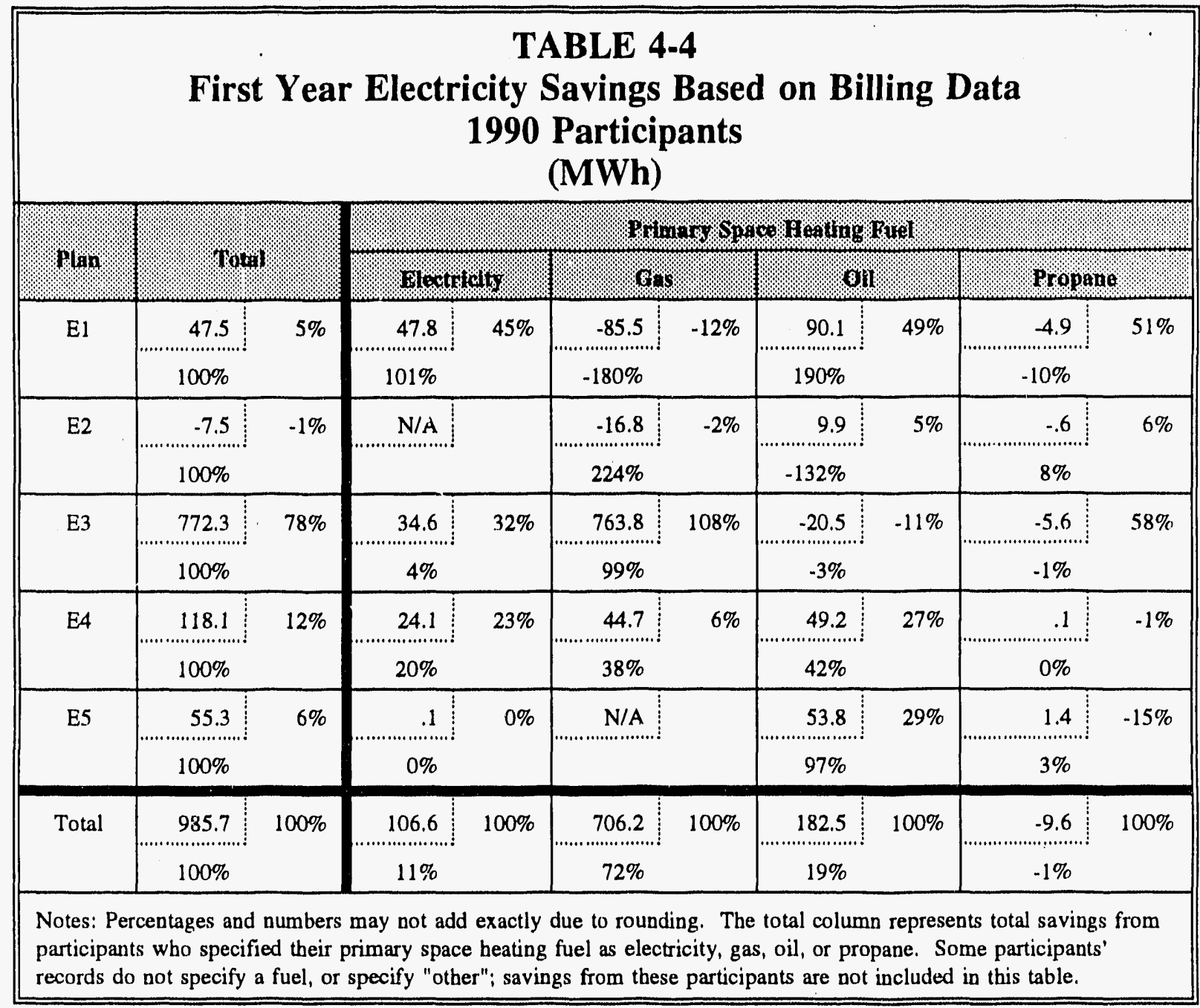

The 1990 participant analyses indicate that the program passed its initial "ramping up" from 1988 and 1989 participation and is now mature in its process to produce the energy savings for which it was designed. 


\subsection{FIRST YEAR ELECTRICITY SAVINGS BASED ON ENGINEERING ESTIMATES}

Engineering estimates of first year electricity savings from 1989 installations show a net savings of $861 \mathrm{MWh}$, over half of which came from plan E3 (table 4-5). This total, along with subtotals for plans E1, E3, and E5, is much higher lan that indicated by the billing data analysis (see table 4.1). However, the engineering estimates of savings from plans E2 and E4 (particularly E4) are much lower than the savings indicated by the billing data analysis. The two sources of estimates are consistent in attributing larger electricity savings to urban participants than rural participants.

The overall pattern of savings based on engineering estimates shows over half of the savings coming from plan E3, and eighty-five percent coming from plans E1 and E3 combined. This is primarily a reflection of the fact that over ninety percent of 1989 participants with electric space heat participated under plans E1 and E3 (see chapter 3). Urban and renter participants also accounted for disproportionately large shares of total electricity savings, again due to higher participation among these groups.

\begin{tabular}{|c|c|c|c|c|c|c|c|c|c|c|}
\hline & st Yea & Eler & city S & $\begin{array}{r}\text { TA } \\
\text { lving } \\
989 \mathrm{P}\end{array}$ & $\begin{array}{l}\text { E } 4-5 \\
\text { Based } \\
\text { rticip } \\
\text { Wh) }\end{array}$ & $\begin{array}{l}\text { on } E \\
\text { nts }\end{array}$ & neer & g Es & mates & \\
\hline plar & ro: & & 106 & & nu & & $0 \%$ & & nent & \\
\hline El & 241.6 & $28 \%$ & 154.7 & $26 \%$ & 86.9 & $34 \%$ & 78.7 & $28 \%$ & 161.9 & $28 \%$ \\
\hline & $100 \%$ & & $64 \%$ & & $36 \%$ & & $33 \%$ & & $67 \%$ & \\
\hline E2 & 14.7 & $2 \%$ & 7.0 & $1 \%$ & 7.7 & $3 \%$ & 11.6 & $4 \%$ & 3.1 & $1 \%$ \\
\hline & $100 \%$ & & $48 \%$ & & $52 \%$ & & $79 \%$ & & $21 \%$ & \\
\hline E3 & 487.0 & $57 \%$ & 368.3 & $61 \%$ & 118.7 & $46 \%$ & 138.6 & $50 \%$ & 348.4 & $60 \%$ \\
\hline & $100 \%$ & & $76 \%$ & & $24 \%$ & & $28 \%$ & & $72 \%$ & \\
\hline E4 & 52.8 & $6 \%$ & 38.0 & $6 \%$ & 14.9 & $6 \%$ & 19.8 & $7 \%$ & 33.1 & $6 \%$ \\
\hline & $100 \%$ & & $72 \%$ & & $28 \%$ & & $38 \%$ & & $63 \%$ & \\
\hline E5 & 65.3 & $8 \%$ & $\begin{array}{r}37.4 \\
\ldots \ldots \ldots\end{array}$ & $6 \%$ & 27.9 & $11 \%$ & 30.1 & $11 \%$ & 35.2 & $6 \%$ \\
\hline & $100 \%$ & & $57 \%$ & & $43 \%$ & & $46 \%$ & & $54 \%$ & \\
\hline Total & 861.4 & $100 \%$ & 605.4 & $100 \%$ & 256.0 & $100 \%$ & 278.8 & $100 \%$ & 581.7 & $100 \%$ \\
\hline & $100 \%$ & & $70 \%$ & & & & $32 \%$ & & $68 \%$ & \\
\hline
\end{tabular}


Both the billing data analysis and the engineering estimates show larger electricity savings from participants with electric space heat than from participants with other forms of space heat (see tables 4-2 and 4-6). Indeed, both sources estimate overall savings from electric space heating participants to be just over $550 \mathrm{MWh}$. The engineering estimates indicate that, among electric space heating participants, the savings came largely from plans E1 and E3. As discussed above, this is primarily driven by the high number of electric space heating participants in these plans. The pattern of savings by oil heating participants was similar to that of electric heating participants, but savings among gas and propane participants came almost exclusively from plan E3. This is despite much higher participation in plans E4 and E5.

Participants with electric space heat were the primary source of electricity savings for every plan but plan E2, which realized greater electricity savings from participants with oil space heat. Since plan E2 was designed to target oil heating participants, most of the participants in this plan had oil space heat.

\begin{tabular}{|c|c|c|c|c|c|c|c|c|c|c|}
\hline \multicolumn{11}{|c|}{$\begin{array}{c}\text { TABLE 4-6 } \\
\text { First Year Electricity Savings Based on Engineering Estimates } \\
1989 \text { Participants } \\
\text { (MWh) }\end{array}$} \\
\hline \multirow{2}{*}{ 19an. } & \multirow{2}{*}{\multicolumn{2}{|c|}{ Total }} & \multicolumn{8}{|c|}{ 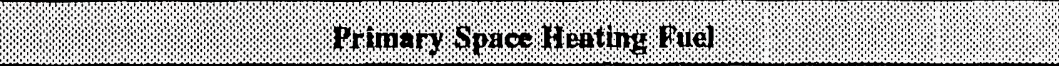 } \\
\hline & & & \multicolumn{2}{|c|}{ eirctrictis? } & \multicolumn{2}{|c|}{8.88} & \multicolumn{2}{|c|}{$8 \%$} & \multicolumn{2}{|c|}{ Iropane. } \\
\hline \multirow[t]{2}{*}{ E1 } & 240.7 & $28 \%$ & 200.6 & $36 \%$ & 10.1 & $5 \%$ & 30.0 & $28 \%$ & 0.0 & $0 \%$ \\
\hline & $100 \%$ & & $83 \%$ & & $4 \%$ & & $12 \%$ & & $0 \%$ & \\
\hline \multirow[t]{2}{*}{ E2 } & 14.1 & $2 \%$ & $\begin{array}{r}2.9 \\
\ldots \\
\ldots\end{array}$ & $1 \%$ & 0.5 & $0 \%$ & 10.7 & $10 \%$ & 0.0 & $0 \%$ \\
\hline & $100 \%$ & & $21 \%$ & & $4 \%$ & & $76 \%$ & & $0 \%$ & \\
\hline \multirow[t]{2}{*}{ E3 } & 483.9 & $57 \%$ & 257.2 & $46 \%$ & 175.1 & $90 \%$ & 51.5 & $49 \%$ & 0.1 & $100 \%$ \\
\hline & $100 \%$ & & $53 \%$ & & $36 \%$ & & $11 \%$ & & $0 \%$ & \\
\hline \multirow[t]{2}{*}{ E4 } & 51.6 & $6 \%$ & 36.8 & $7 \%$ & 8.3 & $4 \%$ & 6.5 & $6 \%$ & 0.0 & $0 \%$ \\
\hline & $100 \%$ & & $71 \%$ & & $16 \%$ & & $13 \%$ & & $0 \%$ & \\
\hline \multirow[t]{2}{*}{ E5 } & 65.2 & $8 \%$ & 57.2 & $10 \%$ & 1.3 & $1 \%$ & 6.7 & $6 \%$ & 0.0 & $0 \%$ \\
\hline & $100 \%$ & & $88 \%$ & & $2 \%$ & & $10 \%$ & & $0 \%$ & \\
\hline \multirow[t]{2}{*}{ Total } & 855.4 & $100 \%$ & 554.7 & $100 \%$ & $\begin{array}{r}195.2 \\
195\end{array}$ & $100 \%$ & 105.4 & $100 \%$ & 0.1 & $100 \%$ \\
\hline & $100 \%$ & & $65 \%$ & & $23 \%$ & & $12 \%$ & & $0 \%$ & \\
\hline
\end{tabular}


The engineering estimates of first year electricity savings of 1990 participants (table 4-7) are very similar to the savings estimates based on billing data (table 4-3). Overall electricity savings were estimated by both sources to be slightly higher that one GWh, two-thirds of which came from plan E3. The engineering estimates also confirm the pattern of larger overall savings from urban and renter participants than from rural and owner participants. The only exception to this pattern in the engineering estimates is in plan E2, which shows higher savings from owners. The analysis of savings based on billing data also shows greater savings from owners in this plan. This is primarily driven by a larger plan E2 participation by owners, which may indicate a higher incidence of oil space heat among owners than among renters (see chapter 3 ).

The engineering estimates of savings from 1990 participants shows a higher share of savings from plan E4 than was the case for 1989 installations, as a result of higher participation levels. Another change from 1989 is that rural participants account for a much larger share of savings, despite the fact that the overall urban/rural demographics remained roughly the same in 1990, and the share of nural participants in the intensive plan E5 fell from sixty percent to forty percent.

\begin{tabular}{|c|c|c|c|c|c|c|c|c|c|c|}
\hline \multicolumn{11}{|c|}{$\begin{array}{c}\text { TABLE 4-7 } \\
\text { First Year Electricity Savings Based on Engineering Estimates } \\
1990 \text { Participants } \\
\text { (MWh) }\end{array}$} \\
\hline rion. & \multicolumn{2}{|c|}{ Troril } & \multicolumn{2}{|c|}{ Irban. } & \multicolumn{2}{|c|}{ Rural } & \multicolumn{2}{|c|}{ ourner: } & \multicolumn{2}{|c|}{ Binter } \\
\hline \multirow[t]{2}{*}{ E1 } & 128.6 & $11 \%$ & 76.1 & $12 \%$ & 52.5 & $10 \%$ & 60.1 & $18 \%$ & 68.5 & $8 \%$ \\
\hline & $100 \%$ & & $59 \%$ & & $41 \%$ & & $47 \%$ & & $53 \%$ & \\
\hline \multirow[t]{2}{*}{ E2 } & $\begin{array}{r}44.7 \\
44 \ldots \ldots\end{array}$ & $4 \%$ & 27.7 & $4 \%$ & 17.1 & $3 \%$ & 24.1 & $7 \%$ & 20.6 & $2 \%$ \\
\hline & $100 \%$ & & $62 \%$ & & $38 \%$ & & $54 \%$ & & $46 \%$ & \\
\hline \multirow[t]{2}{*}{ E3 } & 767.4 & $65 \%$ & 412.2 & $62 \%$ & 355.2 & $69 \%$ & 172.3 & $53 \%$ & 595.2 & $70 \%$ \\
\hline & $100 \%$ & & $54 \%$ & & $46 \%$ & & $22 \%$ & & $78 \%$ & \\
\hline \multirow[t]{2}{*}{ E4 } & $\begin{array}{r}125.2 \\
.25 .2\end{array}$ & $11 \%$ & 62.9 & $10 \%$ & 62.3 & $12 \%$ & 41.8 & $13 \%$ & 83.4 & $10 \%$ \\
\hline & $100 \%$ & & $50 \%$ & & $50 \%$ & & $33 \%$ & & $67 \%$ & \\
\hline \multirow[t]{2}{*}{ E5 } & 106.9 & $9 \%$ & 81.0 & $12 \%$ & 25.9 & $5 \%$ & 28.5 & $9 \%$ & $\begin{array}{r}78.4 \\
.78 .4\end{array}$ & $9 \%$ \\
\hline & $100 \%$ & & $76 \%$ & & $24 \%$ & & $27 \%$ & & $73 \%$ & \\
\hline \multirow[t]{2}{*}{ Total } & $1,172.9$ & $100 \%$ & 659.8 & $100 \%$ & 513.1 & $100 \%$ & 326.8 & $100 \%$ & 846.1 & $100 \%$ \\
\hline & $100 \%$ & & $56 \%$ & & $44 \%$ & & $28 \%$ & & $72 \%$ & \\
\hline
\end{tabular}


The engineering estimates of first year electricity savings by primary space heating fuel (table 4-8) attribute ninety percent of overall program savings to electric and gas space heating participants, in contrast to the savings estimates based on billing data (table 4-4), which indicated that over two-thirds of the first year electricity savings came from gas space heating participants. The 1990 engineering estimates of savings from oil heating participants is also much higher than the 1989 engineering estimate. The larger 1990 savings in this category come primarily from plan E3, which in 1990 experienced a large increase in participation share by oil space heating customers.

\begin{tabular}{|c|c|c|c|c|c|c|c|c|c|c|}
\hline \multicolumn{11}{|c|}{$\begin{array}{l}\text { TABLE 4-8 } \\
\text { avings Based on Engineering Estimates } \\
990 \text { Participants } \\
\quad \text { (MWh) }\end{array}$} \\
\hline \multirow{2}{*}{ Yan } & \multirow{2}{*}{\multicolumn{2}{|c|}{ 1061 }} & \multicolumn{8}{|c|}{ 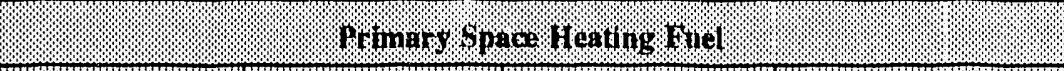 } \\
\hline & & & \multicolumn{2}{|c|}{ 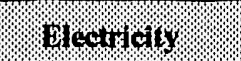 } & \multicolumn{2}{|c|}{0} & \multicolumn{2}{|l|}{811} & \multicolumn{2}{|c|}{ propane } \\
\hline \multirow[t]{2}{*}{ E1 } & 124.3 & $12 \%$ & $\begin{array}{c}65.8 \\
\ldots \ldots \ldots\end{array}$ & $16 \%$ & 13.2 & $14 \%$ & 44.4 & $9 \%$ & 0.9 & $21 \%$ \\
\hline & $100 \%$ & & $53 \%$ & & $11 \%$ & & $36 \%$ & & $1 \%$ & \\
\hline \multirow[t]{2}{*}{$\mathrm{E} 2$} & 44.4 & $4 \%$ & 3.0 & $1 \%$ & 4.5 & $5 \%$ & 36.3 & $7 \%$ & 0.6 & $14 \%$ \\
\hline & $100 \%$ & & $7 \%$ & & $10 \%$ & & $82 \%$ & & $1 \%$ & \\
\hline \multirow[t]{2}{*}{ E3 } & 653.1 & $65 \%$ & 304.3 & $72 \%$ & 26.7 & $28 \%$ & 319.8 & $66 \%$ & 2.3 & $53 \%$ \\
\hline & $100 \%$ & & $47 \%$ & & $4 \%$ & & $49 \%$ & & $0 \%$ & \\
\hline \multirow[t]{2}{*}{$\mathrm{E} 4$} & 114.3 & $11 \%$ & 42.7 & $10 \%$ & 38.1 & $39 \%$ & 33.3 & $7 \%$ & 0.2 & $5 \%$ \\
\hline & $100 \%$ & & $37 \%$ & & $33 \%$ & & $29 \%$ & & $0 \%$ & \\
\hline \multirow[t]{2}{*}{ E5 } & 70.6 & $7 \%$ & 4.5 & $1 \%$ & 14.2 & $15 \%$ & 51.7 & $11 \%$ & 0.2 & $5 \%$ \\
\hline & $100 \%$ & & $6 \%$ & & $20 \%$ & & $73 \%$ & & $0 \%$ & \\
\hline \multirow[t]{2}{*}{ Total } & $1,006.9$ & $100 \%$ & 420.4 & $100 \%$ & 96.7 & $100 \%$ & 485.5 & $100 \%$ & 4.3 & $100 \%$ \\
\hline & $100 \%$ & & $42 \%$ & & $10 \%$ & & $48 \%$ & & $0 \%$ & \\
\hline $\begin{array}{l}\text { Notes: } \\
\text { participa } \\
\text { do not s }\end{array}$ & $\begin{array}{l}\text { ges and } n \\
\text { o specifiec } \\
\text { a fuel, or }\end{array}$ & $\begin{array}{l}\text { hers } \mathrm{n} \\
\text { heir pr } \\
\text { ecify "}\end{array}$ & $\begin{array}{l}\text { ot add } \\
\text { space } \\
\text {; savin }\end{array}$ & ctly du & round & $\begin{array}{l}\text { The } \\
\text { ity, gas, } \\
\text { nts are }\end{array}$ & $\begin{array}{l}\text { tal column } \\
\text { il, or prop } \\
\text { t included }\end{array}$ & $\begin{array}{l}\text { epresent } \\
\text { e. Som } \\
\text { this tat }\end{array}$ & $\begin{array}{l}\text { ts total saving } \\
\text { ne participant }\end{array}$ & $\begin{array}{l}\text { from } \\
\text { records }\end{array}$ \\
\hline
\end{tabular}




\subsection{LIFETIME ELECTRICITY SAVINGS BASED ON ENGINEERING ESTIMATES}

Table 4-9 shows engineering estimates of lifetime electricity savings from 1989 participants. Total savings are estimated at $6.4 \mathrm{GWh}$, half from plan E3 and one quarter from plan E1. As with first year savings estimates, urban and renter participants accounted for more savings than rural or owner participants.

The patterns of savings are similar to those of first year electricity savings (see table 4-5). The shares of lifetime savings from plans E4 and E5 are higher than for first year savings hecause the measures received under these plans generally have relatively long lifespans. The share of savings from owner participants is also higher for lifetime savings than for first year savings; this driven by higher participation in plan E5.

\begin{tabular}{|c|c|c|c|c|c|c|c|c|c|c|}
\hline \multicolumn{11}{|c|}{$\begin{array}{l}\text { TABLE } 4-9 \\
\text { ings Based on Engineering Estimates } \\
89 \text { Participants } \\
\quad \text { (MWh) }\end{array}$} \\
\hline ron & \multicolumn{2}{|c|}{18011} & \multicolumn{2}{|c|}{ monn. } & \multicolumn{2}{|c|}{ niral } & \multicolumn{2}{|c|}{80100} & \multicolumn{2}{|c|}{ Benter } \\
\hline \multirow[t]{2}{*}{ El } & $1,611.9$ & $25 \%$ & $1,103.3$ & $24 \%$ & 508.5 & $28 \%$ & 592.3 & $27 \%$ & $1,011.9$ & $24 \%$ \\
\hline & $100 \%$ & & $68 \%$ & & $32 \%$ & & $37 \%$ & & $63 \%$ & \\
\hline \multirow[t]{2}{*}{$\mathrm{E} 2$} & 138.4 & $2 \%$ & 80.8 & $2 \%$ & 57.6 & $3 \%$ & 104.8 & $5 \%$ & 33.6 & $1 \%$ \\
\hline & $100 \%$ & & $58 \%$ & & $42 \%$ & & $76 \%$ & & $24 \%$ & \\
\hline \multirow[t]{2}{*}{ E3 } & $3,314.5$ & $52 \%$ & $2,574.3$ & $56 \%$ & 740.2 & $41 \%$ & 997.6 & $45 \%$ & $2,317.0$ & $55 \%$ \\
\hline & $100 \%$ & & $78 \%$ & & $22 \%$ & & $30 \%$ & & $70 \%$ & \\
\hline \multirow[t]{2}{*}{$\mathrm{E} 4$} & 533.8 & $8 \%$ & 381.2 & $8 \%$ & 152.6 & $8 \%$ & 196.9 & $9 \%$ & 337.0 & $8 \%$ \\
\hline & $100 \%$ & & $71 \%$ & & $29 \%$ & & $37 \%$ & & $63 \%$ & \\
\hline \multirow[t]{2}{*}{ E5 } & 820.5 & $13 \%$ & 473.2 & $10 \%$ & 347.3 & $19 \%$ & 334.4 & $15 \%$ & 486.0 & $12 \%$ \\
\hline & $100 \%$ & & $58 \%$ & & $42 \%$ & & $41 \%$ & & $59 \%$ & \\
\hline \multirow[t]{2}{*}{ Total } & $6,419.1$ & $100 \%$ & $4,612.9$ & $100 \%$ & $1,806.2$ & $100 \%$ & $2,226.0$ & $100 \%$ & $4,185.5$ & $100 \%$ \\
\hline & $100 \%$ & & $72 \%$ & & $28 \%$ & & $35 \%$ & & $65 \%$ & \\
\hline
\end{tabular}


The most significant finding from the space heating fuel analysis comparing first year and lifetime engineering estimates of savings for 1989 participants is a higher share of savings from oil heating participants and a lower share from electric heating participants (tables 4-10 and 4-6). The share of lifetime savings for electric space heating participants fell primarily because of their heavy participation in plans E1 and E3, which provide short-life measures. The share of savings by plan for oil participants are not significantly different for lifetime savings than for first year savings, indicating that oil heating participants may have generally received longer-lived measures across all plans than did participants with other fuels for space heating.

\begin{tabular}{|c|c|c|c|c|c|c|c|c|c|c|}
\hline \multicolumn{11}{|c|}{$\begin{array}{c}\text { TABLE 4-10 } \\
\text { Lifetime Electricity Savings Based on Engineering Estimates } \\
1989 \text { Participants } \\
\text { (MWh) }\end{array}$} \\
\hline \multirow{2}{*}{ Plan. } & \multirow{2}{*}{\multicolumn{2}{|c|}{ rogit: }} & \multicolumn{8}{|c|}{ 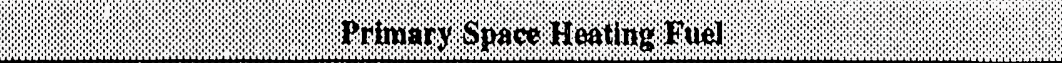 } \\
\hline & & & \multicolumn{2}{|c|}{ miternicis? } & \multicolumn{2}{|c|}{ G.s. } & \multicolumn{2}{|c|}{811} & \multicolumn{2}{|c|}{ Tropsne? } \\
\hline \multirow[t]{2}{*}{ E1 } & $1,604.9$ & $25 \%$ & $1,190.6$ & $31 \%$ & 92.4 & $6 \%$ & 321.9 & $29 \%$ & 0.0 & $0 \%$ \\
\hline & $100 \%$ & & $74 \%$ & & $6 \%$ & & $20 \%$ & & $0 \%$ & \\
\hline \multirow[t]{2}{*}{ E2 } & 134.0 & $2 \%$ & 9.5 & $0 \%$ & 4.8 & $0 \%$ & 119.7 & $11 \%$ & 0.0 & $0 \%$ \\
\hline & $100 \%$ & & $7 \%$ & & $4 \%$ & & $89 \%$ & & $0 \%$ & \\
\hline \multirow[t]{2}{*}{ E3 } & $3,291.5$ & $52 \%$ & $1,489.4$ & $39 \%$ & $1,268.6$ & $87 \%$ & 533.0 & $48 \%$ & 0.5 & $100 \%$ \\
\hline & $100 \%$ & & $45 \%$ & & $39 \%$ & & $16 \%$ & & $0 \%$ & \\
\hline \multirow[t]{2}{*}{ E4 } & 521.5 & $8 \%$ & 374.1 & $10 \%$ & 80.1 & $6 \%$ & 67.3 & $6 \%$ & 0.0 & $0 \%$ \\
\hline & $100 \%$ & & $72 \%$ & & $15 \%$ & & $13 \%$ & & $0 \%$ & \\
\hline \multirow[t]{2}{*}{ E5 } & 819.4 & $13 \%$ & 734.7 & $19 \%$ & 11.2 & $1 \%$ & 73.5 & $7 \%$ & 0.0 & $0 \%$ \\
\hline & $100 \%$ & & $90 \%$ & & $1 \%$ & & $9 \%$ & & $0 \%$ & \\
\hline \multirow[t]{2}{*}{ Total } & $6,371.5$ & $100 \%$ & $3,798.3$ & $100 \%$ & $1,457.2$ & $100 \%$ & $1,115.5$ & $100 \%$ & 0.5 & $100 \%$ \\
\hline & $100 \%$ & & $60 \%$ & & $23 \%$ & & $18 \%$ & & $0 \%$ & \\
\hline
\end{tabular}


Engineering estimates indicate that lifetime electricity savings from 1990 installations were approximately $8.5 \mathrm{GWh}$, an increase of thirty three percent over lifetime savings from 1989 installations (table 4-11). The most significant changes by plan from 1989's lifetime savings occurred in plan E3, which has a smaller share of lifetime savings than of first year savings, and plan E4, which has a larger share of lifetime savings than first year savings. These changes are due to the long average life of E4's measures and the shorter life of measures available under plan E3. Owners represent a higher share of lifetime savings than of first year savings, primarily due to a higher share of savings from plan E4. This occurred despite lower owner participation in plan E4, and may indicate that owners generally received longer-life measures under plan $\mathrm{E} 4$ than did renters.

\begin{tabular}{|c|c|c|c|c|c|c|c|c|c|c|}
\hline \multicolumn{11}{|c|}{$\begin{array}{l}\text { TABLE 4-11 } \\
\text { Lifetime Electricity Savings Based on Engineering Estimates } \\
1990 \text { Participants } \\
\text { (MWh) }\end{array}$} \\
\hline lisan. & \multicolumn{2}{|c|}{ rotal. } & \multicolumn{2}{|c|}{109601} & \multicolumn{2}{|c|}{ Rinril: } & \multicolumn{2}{|c|}{ orrat. } & \multicolumn{2}{|c|}{ Renter } \\
\hline \multirow[t]{2}{*}{ E1 } & 877.9 & $10 \%$ & 550.4 & $12 \%$ & 327.5 & $9 \%$ & 421.7 & $16 \%$ & 456.2 & $8 \%$ \\
\hline & $100 \%$ & & $63 \%$ & & $37 \%$ & & $48 \%$ & & $52 \%$ & \\
\hline \multirow[t]{2}{*}{ E2 } & 371.3 & $4 \%$ & 218.5 & $5 \%$ & 152.8 & $4 \%$ & 215.0 & $8 \%$ & 156.3 & $3 \%$ \\
\hline & $100 \%$ & & $59 \%$ & & $41 \%$ & & $58 \%$ & & $42 \%$ & \\
\hline \multirow[t]{2}{*}{ E3 } & $5,175.6$ & $61 \%$ & $2,680.9$ & $56 \%$ & $2,494.7$ & $66 \%$ & $1,253.5$ & $47 \%$ & $3,922.1$ & $67 \%$ \\
\hline & $100 \%$ & & $52 \%$ & & $48 \%$ & & $24 \%$ & & $76 \%$ & \\
\hline \multirow[t]{2}{*}{$\mathrm{E} 4$} & $1,290,0$ & $15 \%$ & 676.2 & $14 \%$ & 613.4 & $16 \%$ & 520.0 & $19 \%$ & 769.6 & $13 \%$ \\
\hline & $100 \%$ & & $52 \%$ & & $48 \%$ & & $40 \%$ & & $60 \%$ & \\
\hline \multirow[t]{2}{*}{ E5 } & 831.0 & $10 \%$ & 632.4 & $13 \%$ & 198.6 & $5 \%$ & 257.6 & $10 \%$ & 573.4 & $10 \%$ \\
\hline & $100 \%$ & & $76 \%$ & & $24 \%$ & & $31 \%$ & & $69 \%$ & \\
\hline \multirow[t]{2}{*}{ Total } & $8,545.4$ & $100 \%$ & $\begin{array}{r}4,758.4 \\
\end{array}$ & $100 \%$ & $\begin{array}{r}3,787.0 \\
\end{array}$ & $100 \%$ & $2,667.8$ & $100 \%$ & $5,877.6$ & $100 \%$ \\
\hline & $100 \%$ & & $56 \%$ & & $44 \%$ & & $31 \%$ & & $69 \%$ & \\
\hline
\end{tabular}


As with estimates of savings from 1989 installations, the most significant difference between 1990 lifetime and first year. estimates of savings by space heating fuel is a slight increase in the share of savings by oil heating customers and a decrease in the share of savings by electric space heat customers. Most of the savings of electric space heating customers came from the generally short-lived measures in plan E3, while oil heating participants seemed generally to receive longer-lived measures under each plan.

\begin{tabular}{|c|c|c|c|c|c|c|c|c|c|c|}
\hline \multicolumn{11}{|c|}{$\begin{array}{l}\text { TABLE 4-12 } \\
\text { ings Based on Engineering Estimates } \\
90 \text { Participants } \\
\quad \text { (MWh) }\end{array}$} \\
\hline \multirow{2}{*}{ riar } & \multirow{2}{*}{\multicolumn{2}{|c|}{ Tota }} & \multicolumn{8}{|c|}{ 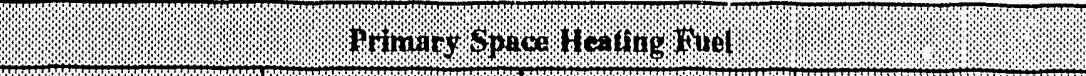 } \\
\hline & & & \multicolumn{2}{|c|}{ Hectricits } & \multicolumn{2}{|c|}{98} & \multicolumn{2}{|c|}{001} & \multicolumn{2}{|c|}{ propano } \\
\hline \multirow[t]{2}{*}{ El } & 842.8 & $11 \%$ & 345.0 & $13 \%$ & 102.9 & $14 \%$ & $\begin{aligned} 386.9 \\
3 \ldots \ldots\end{aligned}$ & $10 \%$ & $\begin{array}{r}8.0 \\
8.0\end{array}$ & $24 \%$ \\
\hline & $100 \%$ & & $41 \%$ & & $12 \%$ & & $46 \%$ & & $1 \%$ & \\
\hline \multirow[t]{2}{*}{$\mathrm{E} 2$} & 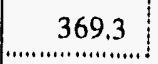 & $5 \%$ & 12.3 & $0 \%$ & 37.7 & $5 \%$ & 313.8 & $8 \%$ & 5.5 & $16 \%$ \\
\hline & $100 \%$ & & $3 \%$ & & $10 \%$ & & $85 \%$ & & $1 \%$ & \\
\hline \multirow[t]{2}{*}{ E3 } & $4,354.9$ & $59 \%$ & $1,723.4$ & $63 \%$ & 203.3 & $28 \%$ & $2,411.3$ & $63 \%$ & 16.9 & $51 \%$ \\
\hline & $100 \%$ & & $40 \%$ & & $5 \%$ & & $55 \%$ & & $0 \%$ & \\
\hline \multirow[t]{2}{*}{$\mathrm{E} 4$} & $1,205.2$ & $16 \%$ & 596.5 & $22 \%$ & 282.5 & $38 \%$ & 324.8 & $8 \%$ & 1.4 & $4 \%$ \\
\hline & $100 \%$ & & $49 \%$ & & $23 \%$ & & $27 \%$ & & & \\
\hline \multirow[t]{2}{*}{ E5 } & $\begin{array}{r}574.4 \\
\ldots \ldots \ldots \ldots \\
\end{array}$ & $8 \%$ & 49.0 & $2 \%$ & 108.2 & $15 \%$ & 415.7 & $11 \%$ & 1.5 & $4 \%$ \\
\hline & $100 \%$ & & $9 \%$ & & $19 \%$ & & $72 \%$ & & $0 \%$ & \\
\hline \multirow[t]{2}{*}{ Total } & 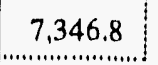 & $100 \%$ & $2,726.2$ & $100 \%$ & 734.6 & $100 \%$ & $3,852.6$ & $100 \%$ & 33.4 & $100 \%$ \\
\hline & $100 \%$ & & $37 \%$ & & $10 \%$ & & $52 \%$ & & $0 \%$ & \\
\hline $\begin{array}{l}\text { Nates: } \\
\text { participa } \\
\text { do not } 5\end{array}$ & ages and & nbers & $\begin{array}{l}\text { not add } \\
\text { y space }\end{array}$ & ly du & round & The $t$ & tal colum & 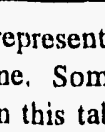 & $\begin{array}{l}\text { total saving } \\
\text { participant }\end{array}$ & ecurds \\
\hline
\end{tabular}




\subsection{TOTAL ENERGY SAVINGS BASED ON ENGINEERING ESTIMATES}

The first year energy savings from the WRAP program increased substantially from the 1989 program year to 1990 (table 4-13). Increases in the first year savings of non-electric fuels were higher than the percent increase in first year electricity savings. The proportion of non-electric savings from combined plans E4 and E5 were higher than the share of electricity savings from these plans, reflecting the higher share of non-electric space heating participants found in plans E4 and E5 (see chapter 3).

\begin{tabular}{|c|c|c|c|c|c|c|c|c|}
\hline \multicolumn{9}{|c|}{$\begin{array}{c}\text { TABLE 4-13 } \\
\text { First Year Fuel Savings Based on Engineering Estimates }\end{array}$} \\
\hline & \multicolumn{8}{|c|}{7018180} \\
\hline & \multicolumn{2}{|c|}{ groctivis: } & \multicolumn{2}{|c|}{ 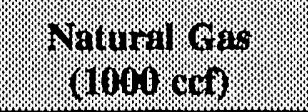 } & \multicolumn{2}{|c|}{1000 gailons? } & \multicolumn{2}{|c|}{ groponitios). } \\
\hline \multicolumn{9}{|c|}{1989 Participants } \\
\hline E1 & 241.6 & $28 \%$ & 28.0 & $25 \%$ & 20.1 & $14 \%$ & 0.1 & $2 \%$ \\
\hline $\mathrm{E} 2$ & 14.7 & $2 \%$ & 3.2 & $3 \%$ & 69.9 & $49 \%$ & 0.0 & $0 \%$ \\
\hline E3 & 487.0 & $57 \%$ & 25.0 & $22 \%$ & 18.4 & $13 \%$ & 2.0 & $36 \%$ \\
\hline $\mathrm{E} A$ & 52.8 & $6 \%$ & 33.6 & $30 \%$ & 14.8 & $10 \%$ & 0.2 & $4 \%$ \\
\hline E5 & 65.3 & $8 \%$ & 22.9 & $20 \%$ & 20.8 & $14 \%$ & 3.2 & $57 \%$ \\
\hline Total & 861.4 & $100 \%$ & 112.8 & $100 \%$ & 144.0 & $100 \%$ & 5.6 & $100 \%$ \\
\hline \multicolumn{9}{|c|}{1990 Participants } \\
\hline E1 & 128.6 & $11 \%$ & 12.2 & $6 \%$ & 9.9 & $4 \%$ & 2.0 & $6 \%$ \\
\hline E2 & 44.7 & $4 \%$ & 8.9 & $4 \%$ & 43.0 & $18 \%$ & 5.3 & $17 \%$ \\
\hline E3 & 767.4 & $65 \%$ & 16.6 & $8 \%$ & 25.6 & $11 \%$ & 3.7 & $12 \%$ \\
\hline $\mathrm{E} 4$ & 125.2 & $11 \%$ & 106.6 & $54 \%$ & 64.7 & $27 \%$ & 13.6 & $43 \%$ \\
\hline E5 & 106.9 & $9 \%$ & 54.0 & $27 \%$ & 94.1 & $40 \%$ & 6.8 & $22 \%$ \\
\hline Total & $1,172.9$ & $100 \%$ & 198.4 & $100 \%$ & 237.2 & $100 \%$ & 31.4 & $100 \%$ \\
\hline
\end{tabular}


Table 4-14 summarizes lifetime fuel savings from 1989 and 1990 WRAP installations. The general relationships.between first year and lifetime electricity savings (see section 4.4) also pertain to other fuel types. The percent of lifetime savings from plans E1 and E3 is generally lower than that for first year savings from these plans. Conversely, the percent of savings from plans E4 and E5 is greater over the lifetime of the measures than in the first year. This shifting of savings is due to the higher average lifespans of measures insialled in the more intensive plans E4 and E5 than in the lower-cost plans E1 and E3.

\begin{tabular}{|c|c|c|c|c|c|c|c|c|}
\hline \multicolumn{9}{|c|}{$\begin{array}{c}\text { TABLE } 4-14 \\
\text { Lifetime Fuel Savings Based on Engineering Estimates }\end{array}$} \\
\hline & \multicolumn{8}{|c|}{ gure: 1918} \\
\hline & \multicolumn{2}{|c|}{ miectinitis? } & \multicolumn{2}{|c|}{ 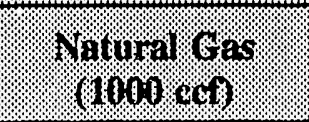 } & \multicolumn{2}{|c|}{1000 gailons; } & \multicolumn{2}{|c|}{ 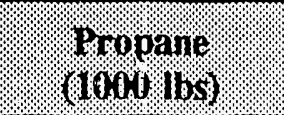 } \\
\hline \multicolumn{9}{|c|}{1989 Participants } \\
\hline E1 & $1,611.9$ & $25 \%$ & 129.6 & $9 \%$ & 91.9 & $5 \%$ & 0.9 & $1 \%$ \\
\hline E2 & 138.4 & $2 \%$ & 46.2 & $3 \%$ & 909.9 & $52 \%$ & 0.0 & $0 \%$ \\
\hline E3 & $3,314.5$ & $52 \%$ & 134.3 & $10 \%$ & 112.7 & $6 \%$ & 10.0 & $13 \%$ \\
\hline $\mathrm{E} 4$ & 533.8 & $8 \%$ & 630.2 & $46 \%$ & 281.9 & $16 \%$ & 0.7 & $1 \%$ \\
\hline E5 & 820.5 & $13 \%$ & 436.2 & $32 \%$ & 345.4 & $20 \%$ & 63.1 & $84 \%$ \\
\hline Total & $6,419.1$ & $100 \%$ & $1,376.5$ & $100 \%$ & $1,741.7$ & $100 \%$ & 74.7 & $100 \%$ \\
\hline \multicolumn{9}{|c|}{1990 Participants } \\
\hline E1 & 877.9 & $10 \%$ & 55.4 & $1 \%$ & 50.9 & $1 \%$ & 13.5 & $2 \%$ \\
\hline $\mathrm{E} 2$ & 371.3 & $4 \%$ & 181.4 & $5 \%$ & 587.7 & $17 \%$ & 87.1 & $15 \%$ \\
\hline E3 & $5,175.6$ & $61 \%$ & 96.7 & $3 \%$ & 150.8 & $4 \%$ & 17.6 & $3 \%$ \\
\hline $\mathrm{E} 4$ & $1,289.6$ & $15 \%$ & $2,377.0$ & $62 \%$ & $1,329.5$ & $38 \%$ & 304.9 & $52 \%$ \\
\hline E5 & 831.0 & $10 \%$ & $1,104.2$ & $29 \%$ & $1,400.6$ & $40 \%$ & 164.5 & $28 \%$ \\
\hline Total & $8,545.4$ & $100 \%$ & $3,814.7$ & $100 \%$ & $3,519.5$ & $100 \%$ & 587.6 & $100 \%$ \\
\hline
\end{tabular}

Figure 4-1 illustrates total energy savings for the WRAP program in MMBtus, by fuel, as approximated by engineering estimates. The graphic includes preliminary engineering estimates of savings for January through November of 1991. Overall, most energy savings are in the form of oil savings, slightly more than a third occur as gas savings, and about ten percent of total energy savings from the WRAP program are electricity savings. However, preliminary 1991 estimates show a much higher share of energy savings from electricity: over twice as high as 1990 for first year savings and almost four times as high as 1990 for lifetime savings. 
FIGURE 4-1

\section{Total Energy Savings Based on Engineering Estimates}

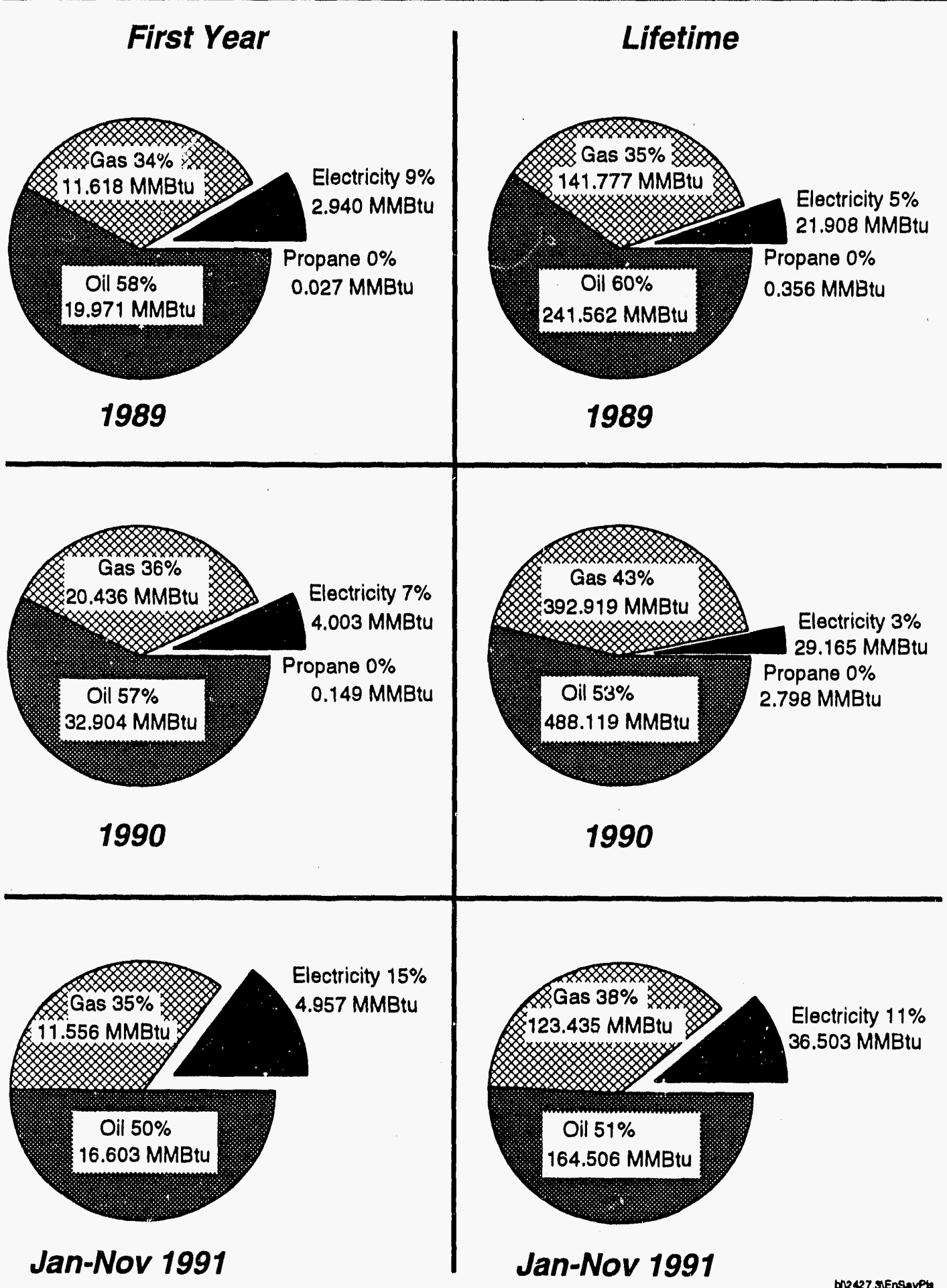

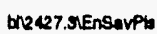




\subsection{ELECTRICITY SAVINGS PER PARTICIPANT}

Participant data was further analyzed through the PRISM model to assess the effectiveness of the WRAP program in achieving electricity savings after one year of measure impact on average per participant. This was accomplished for both the 1989 and 1990 participants, where there was at least one full year of post-installation billing data available. This analysis involved the weather-normalization of the billing data to account for any variation in temperature from the normal. Thus, the pre-installation annual billing data was adjusted for its corresponding weather to create a "normal" usage value that was compared to a comparable usage value created for the post-installation annual usage. The basic analysis is summarized in table 4-15 as first year savings per participant (in $\mathrm{kWh}$ ), and then as a percentage change in base electricity use per participant in table 4-16.

\begin{tabular}{|c|c|c|c|c|c|c|c|c|c|c|}
\hline \multirow{3}{*}{$\%$} & \multicolumn{10}{|c|}{$\begin{array}{c}\text { TABLE } 4-15 \\
\text { First Year Electricity Savings per Participant } \\
\text { Based on Billing Data } \\
(\mathrm{kWh})\end{array}$} \\
\hline & \multicolumn{5}{|c|}{ 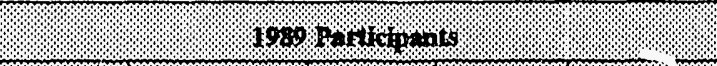 } & \multicolumn{5}{|c|}{1000 oarouctoprits } \\
\hline & ro, & Q18\%1 & n) & $0 \%$ & onoter & 1614 & 101001 & Rard & $0 \%$ rer & $\mathrm{Renter}$ \\
\hline E1 & -12.3 & -28.9 & 6.6 & 61.7 & -83.3 & 166.8 & 62.9 & 315.7 & 239.4 & 128.2 \\
\hline E2 & 237.8 & 194.3 & 303.4 & 312.9 & 34.8 & 59.4 & 157.3 & -157.1 & 405.0 & -364.5 \\
\hline E3 & $-1,258.7$ & 795.2 & $-4,729.3$ & $1,490.3$ & $1,4 \%$ & 644.6 & $1,008.7$ & -193.8 & -64.4 & 968.3 \\
\hline E4 & 1435,3 & $1,383.1$ & $7,481.5$ & 10.84 & $1,072.8$ & 225.9 & 29.4 & 462.4 & 465.9 & 108.8 \\
\hline E5 & 140.7 & 266.3 & 66.8 & -889.1 & 15182 & 55.4 & -105.5 & 329.0 & 148.6 & -20.3 \\
\hline Total & $-500,0$ & 8,87 & -1854.6 & 678.3 & $-1,339.8$ & 345.9 & 477.7 & 106.7 & 169.2 & 460.6 \\
\hline \multirow{2}{*}{ pro } & & \multicolumn{4}{|c|}{ 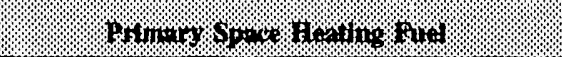 } & & \multicolumn{4}{|c|}{ 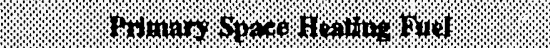 } \\
\hline & 10,1 & mantis & 8 & 619. & $10+1 \%$ & 1011 & 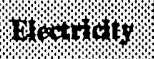 & 18. & 8i1. & 1\%10 \\
\hline El & -12.3 & -169.3 & -195.4 & 238.8 & 73 & 166.8 & 919.1 & -317.8 & 283.2 & -700.5 \\
\hline E2 & 237.8 & N/A & 389.1 & 227.4 & N/A & 59.4 & N/A & -430.8 & 30.9 & -158.6 \\
\hline E3 & $-1,258.7$ & $2,709.3$ & 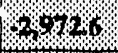 & -188.8 & $-3,153.8$ & 644.6 & 161.5 & $2,893.2$ & -22.6 & -397.0 \\
\hline E4 & 18,8 & $2,202.3$ & 20108 & 312.8 & -212.5 & 225.9 & $1,507.1$ & 152.0 & 207.6 & 24.7 \\
\hline E5 & 140.7 & $3,450.2$ & $1,035.2$ & $-1,401.9$ & $1,301.8$ & 55.4 & N/A & 4.0 & 187.5 & 476.5 \\
\hline Total & -500.0 & $1,563.4$ & $-1,529,3$ & -58.8 & $-1,200.3$ & 345.9 & 329.4 & 755.4 & 108.8 & -210.3 \\
\hline
\end{tabular}




\begin{tabular}{|c|c|c|c|c|c|c|c|c|c|c|}
\hline \multirow{3}{*}{4} & \multicolumn{9}{|c|}{$\begin{array}{l}\text { TABLE 4-16 } \\
\text { First Year Electricity Savings per Participant } \\
\text { Based on Billing Data } \\
\text { (percent) }\end{array}$} & \\
\hline & \multicolumn{5}{|c|}{108010101015} & \multicolumn{5}{|c|}{ 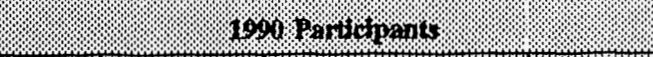 } \\
\hline & 10,4 & 1,64 & $14 n$ & $10 \times 10$ & 24, & 10,1 & 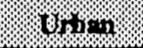 & R144 & 010 & $\mathrm{Runtar}$ \\
\hline E1 & $0 \%$ & $0 \%$ & $0 \%$ & $1 \%$ & $-1 \%$ & $3 \%$ & $1 \%$ & $5 \%$ & $3 \%$ & $2 \%$ \\
\hline E2 & $3 \%$ & $3 \%$ & $5 \%$ & $4 \%$ & $1 \%$ & $1 \%$ & $3 \%$ & $-3 \%$ & $6 \%$ & $-7 \%$ \\
\hline E3 & $-23 \%$ & $12 \%$ & $-131 \%$ & $18 \%$ & $60 \%$ & $8 \%$ & $14 \%$ & $-2 \%$ & $-1 \%$ & $12 \%$ \\
\hline E4 & $18 \%$ & $16 \%$ & $98 \%$ & $21 \%$ & $15 \%$ & $3 \%$ & $0 \%$ & $6 \%$ & $5 \%$ & $2 \%$ \\
\hline E5 & $2 \%$ & $4 \%$ & $1 \%$ & $-10 \%$ & 40 & $1 \%$ & $-2 \%$ & $6 \%$ & $2 \%$ & $0 \%$ \\
\hline Total & $-8 \%$ & $8 \%$ & $-29 \%$ & $9 \%$ & $-23 \%$ & $5 \%$ & $7 \%$ & $1 \%$ & $2 \%$ & $7 \%$ \\
\hline \multirow{2}{*}{ pta } & \multirow{2}{*}{ ro1. } & \multicolumn{4}{|c|}{ 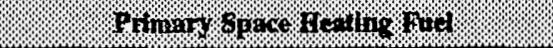 } & & \multicolumn{4}{|c|}{ 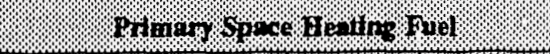 } \\
\hline & & $\mathrm{N}_{4}, \mathrm{H}$ & 0.5. & 011 & ropons & 8902 & 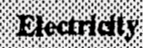 & \% & 018 & roppane \\
\hline E1 & $0 \%$ & $-2 \%$ & $-4 \%$ & $3 \%$ & $7 \%$ & $3 \%$ & $5 \%$ & $-7 \%$ & $5 \%$ & $-7 \%$ \\
\hline E2 & $3 \%$ & N/A & $9 \%$ & $3 \%$ & N/A & $1 \%$ & N/A & $-5 \%$ & $1 \%$ & $-4 \%$ \\
\hline E3 & $-23 \%$ & $19 \%$ & 911 & $-3 \%$ & $-64 \%$ & $8 \%$ & $1 \%$ & $37 \%$ & $0 \%$ & $-6 \%$ \\
\hline E4 & 180 & $14 \%$ & 869 & $4 \%$ & $-10 \%$ & $3 \%$ & $11 \%$ & $2 \%$ & $2 \%$ & $0 \%$ \\
\hline E5 & $2 \%$ & $20 \%$ & $19 \%$ & $-16 \%$ & $29 \%$ & $1 \%$ & N/A & $0 \%$ & $3 \%$ & $16 \%$ \\
\hline Total & $-8 \%$ & $12 \%$ & $-35 \%$ & $-1 \%$ & $-29 \%$ & $5 \%$ & $3 \%$ & $13 \%$ & $2 \%$ & $-3 \%$ \\
\hline
\end{tabular}

Generally, it was found that the 1989 participants increased their annual usage on average approximately $500 \mathrm{kWh}$ (or 8 percent increase from base) after the installation of WRAP measures. These energy increases are largely due to the participants within the E1 (less than 1 percent increase in energy use) and E3 (23 percent increase) program plans (-12.3 and $-1,259 \mathrm{kWh}$ increase respectively). These plans utilized relatively low cost energy savings measures relating to water heating and infiltration measures. The energy savings expected from these program plans are reasonably low compared to the higher cost and comprehensive program plans of E2, E4, and E5. Thus, it might be inferred that the lower cost plans are not comprehensive enough in available energy saving measures to influence the participants' average energy use, or involve a behavior attribute that is not being followed by the participants. However, there are energy savings found for the comprehensive program plans that involve increased insulation levels, major heating system repair or replacement, and comprehensive infiltration measures.

It was also found that statistically significant average energy savings were achieved within the urban (8 percent savings) and owner (9 percent savings) categories of program participants (554 and 678 $\mathrm{kWh}$ saved respectively). Given that there was a larger amount expended within the owner category, on average, than within the tenant participant category, the achieved energy savings follows from that assertion. The urban participant may be experiencing the savings due to the significant improvement even 
minor measures can achieve based on the original condition of the dwelling unit. The 1989 participants who used electricity as a primary space heating fuel also achieved energy savings (12 percent or 1563 $\mathrm{kWh})$ as compared to the gas, oil and propane fuels, which all indicated an increase in use $(1,563,-1,539$, and $-59 \mathrm{kWh}$, or -35 percent, -1 percent, and -29 percent respectively).

Conversely to the 1989 participants, the 1990 participants generally did achieve energy savings, on average, of approximately $346 \mathrm{kWh}$, or 5 percent savings. All participant categories achieved energy savings, on average; the improvement in savings levels over 1989 may be due to an increased emphasis on electricity-saving measures, particularly lighting measures. None of the 1990 participant categories achieved statistically significant savings, however. The energy savings achieved in this program year can be attributed to the success in all of the program plans as each one experienced energy savings. The same is true for the primary heating fuels of electricity ( 3 percent), gas (13 percent) and oil ( 2 percent) or 329 , 755 and 109 saved $\mathrm{kWh}$ respectively. The propane-heating participants did not save on their annual energy as they increased their use by an average of $210 \mathrm{kWh}$ for a 3 percent increase in base electricity use.

Generally, the WRAP program seems to be achieving its primary objective of helping to save energy for its participants. It is indicated in the participant data that the program year of 1989 was still one of "ramping up." There were probably programmatic issues that were influencing the results for that year relating to comprehensiveness of treatment within the dwelling, emphasis on certain categories of customers (such as those falling into the lower-cost program plans), and installation quality. In addition, there was increased emphasis in 1990 on electricity savings, particularly lighting measures; this may have been instrumental in improving electricity savings. Given the improved effect of the 1990 program, it appears that these programmatic elements have been alleviated and the program has now become a successful endeavor. 


\subsection{COST EFFECTIVENESS}

This section evaluates the cost effectiveness of the WRAP program based on two separate approaches ${ }^{1}$. The first approach is to calculate dollars saved per unit of energy or fuel savings. The calculation of program costs per MMBtu of energy savings shows an overall increase in program cost effectiveness from 1989 to 1990 (table 4-17). On a dollar per MMBtu basis, plans E2 and E4 were the most cost effective of all plans in both years. In 1989, measures installed for urban participants and homeowner participants were more cost effective than those measures installed for participants in rural areas or rental homes; however, this pattern reversed in 1990. Installations for participants with primary electric space heat remained less cost effective in terms of total energy savings than installations for participants with other forms of space heating.

\begin{tabular}{|c|c|c|c|c|c|c|c|c|c|c|}
\hline \multirow{3}{*}{ rin } & \multirow{2}{*}{\multicolumn{5}{|c|}{$\begin{array}{l}\text { TABLE } \\
\text { Spent by WRAP per } \\
\text { W }\end{array}$}} & \multirow{2}{*}{\multicolumn{4}{|c|}{10001010196}} & \multirow[b]{3}{*}{ 19n+to } \\
\hline & & & & & & & & & & \\
\hline & \multirow{2}{*}{$\frac{108}{5.26}$} & \multirow{2}{*}{$\frac{80+8}{5.18}$} & \multirow{2}{*}{$\frac{1010}{5.34}$} & \multirow{2}{*}{$\begin{array}{r}18 \% \\
5.44\end{array}$} & $18+1$, & \multirow{2}{*}{$\begin{array}{c}1 \% 8 \\
6.99\end{array}$} & \multirow{2}{*}{$\frac{10 \% 10}{6.48}$} & \multirow{2}{*}{$\begin{array}{c}2140 . \\
7.61\end{array}$} & \multirow{2}{*}{$\begin{array}{c}0.148 \\
6.70\end{array}$} & \\
\hline E1 & & & & & 5.10 & & & & & 7.26 \\
\hline E2 & 1.08 & 0.69 & 3.15 & 0.92 & 2.71 & 1.96 & 1.84 & 2.22 & 1.97 & 1.94 \\
\hline E3 & 5.70 & 6.24 & 5.01 & 5.11 & 6.19 & 6.98 & 7.05 & 6.90 & 6.08 & 8.51 \\
\hline E4 & 1.84 & 1.81 & 1.88. & 1.79 & 1.88 & 1.74 & 2.00 & 1.54 & 2.29 & 1.54 \\
\hline E5 & 3.15 & 3.16 & 3.15 & 3.04 & 3.31 & 2.54 & 2.74 & 2.31 & 2.68 & 2.35 \\
\hline Avg. & 2.56 & 2.14 & 3.17 & 2.13 & 3.26 & 2.41 & 2.61 & 2.20 & 2.68 & 2.20 \\
\hline \multirow{2}{*}{ ?10 } & \multirow{2}{*}{$8 \%$} & \multicolumn{4}{|c|}{ 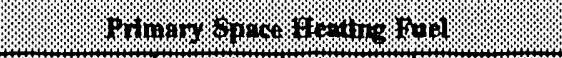 } & \multirow{2}{*}{$48 \%$} & \multicolumn{4}{|c|}{ 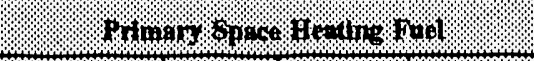 } \\
\hline & & 148, & $8+4$ & 01\% & $140 \%$ & & 04,4015 & $9 \%$ & 80 & $1 \% 0 p, 1$ \\
\hline E1 & 5.26 & 3.27 & 5.34 & 5.32 & 9.50 & 6.99 & 4.75 & 7.32 & 6.06 & 4.54 \\
\hline E2 & 1.08 & 41.68 & 3.83 & 0.87 & N/A & 1.96 & 70.56 & 1.29 & 1.97 & 1.15 \\
\hline E3 & 5.70 & 4.39 & 6.65 & 4.76 & 7.40 & 6.98 & 6.46 & 5.84 & 6.87 & 7.05 \\
\hline $\mathrm{E} 4$ & 1.84 & 6.44 & 1.80 & 1.75 & 7.42 & 1.74 & 8.36 & 1.45 & 1.96 & 1.24 \\
\hline E5 & 3.15 & 6.58 & 2.46 & 3.16 & 2.64 & 2.54 & 8.70 & 1.82 & 2.64 & 1.18 \\
\hline Avg. & 2.56 & 4.74 & 2.92 & 2.02 & 3.27 & 2.41 & 6.98 & 1.73 & 2.60 & 1.43 \\
\hline \multicolumn{11}{|c|}{$\begin{array}{l}\text { Note: Dollars spent by WRAP are nominal dollar installation costs reported by the WRAPTRACK Database plus estimated } \\
\text { administrative costs of } 28.204 \text { percent. Savings are engineering estimates of lifetime savings. The following factors were used to } \\
\text { convert fuel savings to Btu energy savings: } 1 \mathrm{kWh}=3.41 \mathrm{Btu}, 1 \mathrm{ccf} \text { gas }=103 \mathrm{Btu}, 1 \mathrm{gallon} \text { oil }=138.69 \mathrm{Btu} \text {, and } 1 \mathrm{lb} \text { propane = } \\
21.633 \text { Btu. }\end{array}$} \\
\hline
\end{tabular}

1. This evaluation does not include any of the traditional California cost-benefit tests, nor does it attempt to quantify in any way indirect or external costs or benefits. Additional data on installation and program costs is included in Appendix E. 
The calculation of dollars spent by Northeast Utilities (NU) per $\mathrm{kWh}$ saved indicates a decrease in overall cost effectiveness from 1989 tc 1990 , as cost per $\mathrm{kWh}$ increased eighty percent from $\$ 0.10$ to $\$ 0.18$ (table 4-18). This may be due to a possible increase in the percentage of measures affecting oil consumption. Such an increase is probable because the number of participants with primary oil space heating increased significantly from 1989 to 1990, from 44 percent to 62 percent. While Northeast Utilities pays for measures which save oil, no electricity savings are realized for these measures, and therefore overall cost effectiveness from NU's perspective decreases.

Installations among renters were more cost effective for $\mathrm{NU}$ overall than were installations among owners. In both years, the cost per $\mathrm{kWh}$ among owners was three times as high as the cost among renters. But, while urban installations were more cost effective in 1989, rural installations were more cost effective in 1990. Installations for participants with primary electric space heating remained more cost effective in terms of electricity savings $(\$ 0.02 / \mathrm{kWh})$ than installations for participants with other primary space heating fuels.

\begin{tabular}{|c|c|c|c|c|c|c|c|c|c|c|}
\hline \multirow{3}{*}{ ron } & \multicolumn{10}{|c|}{$\begin{array}{c}\text { TABLE 4-18 } \\
\text { Dollars Spent by NU per kWh Electricity Saved }\end{array}$} \\
\hline & \multicolumn{5}{|c|}{ 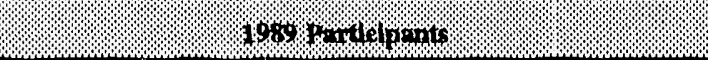 } & \multicolumn{5}{|c|}{10450101975} \\
\hline & 100 & $10 b_{4}$ & nins & 10401 & $\mathrm{H} n \mathrm{r}, \mathrm{r}$ & 100 & 0\%, & $\mathrm{Hor} / \mathrm{s}$ & 10001 & Montro \\
\hline E1 & 0.07 & 0.05 & 0.10 & 0.11 & 0.04 & 0.08 & 0.08 & 0.10 & 0.10 & 0.07 \\
\hline E2 & 0.88 & 0.81 & 0.97 & 0.95 & 0.65 & 0.47 & 0.51 & 0.42 & 0.55 & 0.36 \\
\hline E3 & 0.05 & 0.05 & 0.07 & 0.07 & 0.04 & 0.06 & 0.05 & 0.06 & 0.08 & 0.05 \\
\hline E4 & 0.15 & 0.10 & 0.26 & 0.20 & 0.11 & 0.32 & 0.34 & 0.31 & 0.42 & 0.26 \\
\hline E5 & 0.23 & 0.20 & 0.28 & 0.38 & 0.14 & 0.70 & 0.61 & 0.97 & 1.58 & 0.30 \\
\hline Avg. & 0.10 & 0.08 & 0.16 & 0.18 & 0.06 & 0.18 & 0.19 & 0.16 & 0.33 & 0.11 \\
\hline \multirow{2}{*}{ 1\% } & \multirow{2}{*}{888} & \multicolumn{4}{|c|}{ 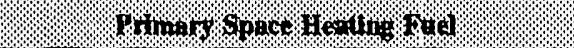 } & & \multicolumn{4}{|c|}{ 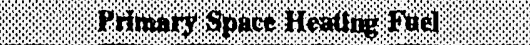 } \\
\hline & & monost & 8.5 & 811 & 81014 & 178 & 1401014 & cow & 01 & 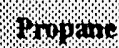 \\
\hline E1 & 0.07 & 0.01 & 0.07 & 0.24 & N/A & 0.08 & 0.02 & 0.05 & 0.14 & 0.12 \\
\hline E2 & 0.88 & 0.14 & 0.03 & 0.91 & N/A & 0.47 & 0.24 & 0.03 & 0.51 & 0.36 \\
\hline E3 & 0.05 & 0.02 & 0.04 & 0.16 & 2.46 & 0.06 & 0.02 & 0.03 & 0.08 & 0.14 \\
\hline E4 & 0.15 & 0.02 & 0.01 & 1.01 & N/A & 0.32 & 0.03 & 0.04 & 1.11 & 5.76 \\
\hline E5 & 0.23 & 0.02 & 0.05 & 2.06 & N/A & 0.70 & 0.03 & 0.04 & 1.23 & 2.74 \\
\hline Avg. & 0.10 & 0.02 & 0.04 & 0.44 & 9.95 & 0.18 & 0.02 & 0.04 & 0.33 & 0.53 \\
\hline
\end{tabular}


The cost to the participating gas companies ${ }^{2}$ per ccf of gas saved decreased by a third from 1989 to 1990 (table 4-19), and remains considerably lower than current retail prices for gas. Plan E4 was the most cost effective of the plans in 1989, and was even more cost effective in 1990. The cost per ccf saved for plan E2 decreased by almost two-thirds from 1989 to 1990, making E2 as cost effective as plan E4.

As was the case for the WRAP cost per MMBtu and the NU cost per kWh, gas company expenditures per ccf saved were lower for urban installations than rural in 1989, and lower for rural installations in 1990. The cost effectiveness of gas company WRAP investments in 1990 was best for installations in primarily gas heated homes, while in 1989 installations in primarily electrically heated homes were the most cost effective.

\begin{tabular}{|c|c|c|c|c|c|c|c|c|c|c|}
\hline \multicolumn{11}{|c|}{ TABLE 4-19 } \\
\hline \multirow{2}{*}{ n1 } & \multicolumn{5}{|c|}{ 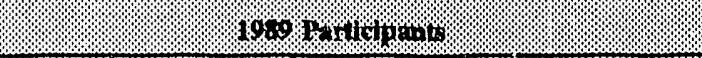 } & \multicolumn{5}{|c|}{ 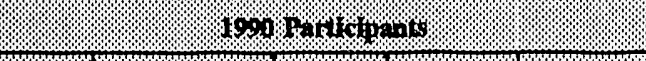 } \\
\hline & 108 & 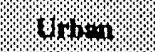 & 340 & $8+40$ & 106ro & 180 & 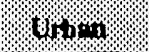 & 1\%14. & opror & $60+4$ \\
\hline E1 & 0.47 & 0.50 & 0.46 & 0.43 & 0.49 & 0.69 & 0.63 & 0.74 & 0.68 & 0.70 \\
\hline $\mathrm{E} 2$ & 0.43 & 0.55 & 0.34 & 0.80 & 0.30 & 0.15 & 0.13 & 0.29 & 0.17 & 0.14 \\
\hline E3 & 0.47 & 0.48 & 0.46 & 0.47 & 0.47 & 0.57 & 0.59 & 0.55 & 0.57 & 1.15 \\
\hline E4 & 0.19 & 0.18 & 0.19 & 0.20 & 0.18 & 0.15 & 0.17 & 0.13 & 0.16 & 0.15 \\
\hline E5 & 0.26 & 0.21 & 0.29 & 0.21 & 0.31 & 0.20 & 0.19 & 0.20 & 0.21 & 0.19 \\
\hline Avg. & 0.27 & 0.25 & 0.29 & 0.27 & 0.27 & 0.18 & 0.20 & 0.17 & 0.21 & 0.17 \\
\hline \multirow{2}{*}{ non } & \multirow{2}{*}{$18 \%$} & \multicolumn{4}{|c|}{ 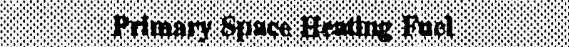 } & & \multicolumn{4}{|c|}{ 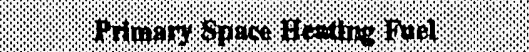 } \\
\hline & & $6+40 \%$ & \$1 & 014 & $10010 \%$ & $A y B$ & 40,104 & 90 & 8018 & 10mpons \\
\hline E1 & 0.47 & 0.20 & 0.51 & 0.23 & N/A & 0.69 & 0.56 & 0.70 & 0.41 & 0.10 \\
\hline E2 & 0.43 & N/A & 0.39 & 0.38 & N/A & 0.15 & N/A & 0.13 & 1.12 & N/A \\
\hline E3 & 0.47 & 0.24 & 0.49 & 0.29 & N/A & 0.57 & 0.88 & 0.58 & 0.37 & 0.77 \\
\hline E4 & 0.19 & 0.21 & 0.19 & 0.43 & N/A & 0.15 & 0.19 & 0.14 & 0.60 & 0.15 \\
\hline E5 & 0.26 & 0.27 & 0.25 & 5.32 & N/A & 0.20 & N/A & 0.18 & 1.46 & N/A \\
\hline Avg. & 0.27 & 0.22 & 0.27 & 0.29 & N/A & 0.18 & 0.63 & 0.17 & 0.65 & 0.31 \\
\hline $\begin{array}{l}\text { Note: } \\
\text { of mea } \\
\text { include } \\
\text { savings }\end{array}$ & $\begin{array}{l}\text { spent b } \\
r \text { wlich } \\
\text { ated ad } \\
\text { hose } m\end{array}$ & $\begin{array}{l}\text { as companie } \\
\text { WRAPTRA } \\
\text { strative cost }\end{array}$ & 28.204 & $\begin{array}{l}\text { entallatio } \\
\text { entry fo } \\
\text { rent. A }\end{array}$ & sis for $m$ & $\begin{array}{l}\text { affec } \\
\text { "othe } \\
\text { al. Sa }\end{array}$ & $\begin{array}{l}\text { gas, plus } 15 \\
\text { "blank," or n }\end{array}$ & Enere & he install & $\begin{array}{l}\text { on costs } \\
\text { t also } \\
\text { ne gas }\end{array}$ \\
\hline
\end{tabular}

2 Yankee Energy Systems has participated in the program since its inception. Currently, both Yankee Energy Systems and Connecticut Natural Gas contribute funds for gas-saving measures. 
As discussed previously, Northeast Utilities pays for the installation of oil-saving measures under the WRAP program. Table 4-20 shows NU's investment per gallon of oil saved. Dollars spent are NU's total contribution to WRAP, not just the cost for oil saving measures. Despite this, costs per gallon were much lower than current retail prices (about $\$ 0.90$ to $\$ 1.00$ per gallon). Cost effectiveness calculations show an increase in cost per gallon, from \$0.38 in 1989 to $\$ 0.44$ in 1990. Plans E2 and E4 were the most cost effective of all plans, and savings from owner participants were less expensive than savings from renters. Installations for participants with oil space heat were far more cost effective (\$0.28 in 1989 and $\$ 0.37$ in 1990) than installations for participants with other primary space heating fuels.

\begin{tabular}{|c|c|c|c|c|c|c|c|c|c|c|}
\hline \multirow{3}{*}{ 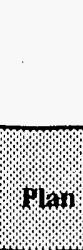 } & \multicolumn{9}{|c|}{ TABLE 4-20 } & \multirow[b]{3}{*}{ nonter } \\
\hline & \multicolumn{5}{|c|}{ (10.97nosponis } & \multicolumn{4}{|c|}{$10001 \% 14,4015$} & \\
\hline & 188 & $80_{10}$ & 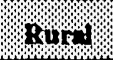 & $007 \%$ & 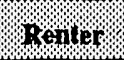 & 148 & 010, & knoul & 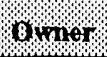 & \\
\hline E1 & 1.14 & 1.14 & 1.15 & 1.02 & 1.43 & 1.45 & 1.37 & 1.57 & 1.25 & 1.87 \\
\hline E2 & 0.13 & 0.08 & 0.44 & 0.12 & 0.37 & 0.30 & 0.28 & 0.32 & 0.29 & 0.31 \\
\hline E3 & 1.51 & 1.90 & 1.05 & 0.97 & 2.66 & 1.90 & 2.02 & 1.79 & 1.19 & 2.73 \\
\hline E4 & 0.28 & 0.28 & 0.27 & 0.24 & 0.33 & 0.31 & 0.34 & 0.29 & 0.38 & 0.26 \\
\hline E5 & 0.56 & 0.59 & 0.53 & 0.53 & 0.63 & 0.42 & 0.43 & 0.39 & 0.41 & 0.44 \\
\hline Avg. & 0.38 & 0.31 & 0.54 & 0.29 & 0.76 & 0.44 & 0.44 & 0.43 & 0.42 & 0.46 \\
\hline \multirow{2}{*}{$\mathrm{rom}$} & \multirow{2}{*}{ ros. } & \multicolumn{4}{|c|}{ 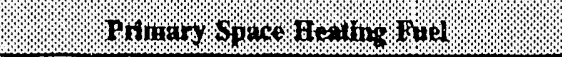 } & & \multicolumn{4}{|c|}{ 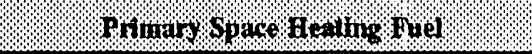 } \\
\hline & & Gactiotis & cos & 11\% & 300,15 & 188 & encting & (5) & 011 & ropare \\
\hline E1 & 1.14 & 97.75 & 22.02 & 0.86 & N/A & 1.45 & N/A & N/A & 1.03 & 27.55 \\
\hline E2 & 0.13 & N/A & $\mathrm{N} / \mathrm{A}$ & 0.12 & N/A & 0.30 & N/A & N/A & 0.27 & $\mathrm{~N} / \mathrm{A}$ \\
\hline E3 & 1.51 & 82.38 & 438.19 & 0.77 & N/A & 1.90 & 129.77 & 27.95 & 1.36 & N/A \\
\hline E4 & 0.28 & N/A & 2.23 & 0.24 & N/A & 0.31 & $\mathrm{~N} / \mathrm{A}$ & 24.71 & 0.27 & N/A \\
\hline E5 & 0.56 & $\mathrm{~N} / \mathrm{A}$ & N/A & 0.44 & N/A & 0.42 & $\mathrm{~N} / \mathrm{A}$ & N/A & 0.37 & N/A \\
\hline Avg. & 0.38 & 151.00 & 70.29 & 0.28 & N/A & 0.44 & 223.07 & 40.83 & 0.37 & 506.94 \\
\hline $\begin{array}{l}\text { Note: } \\
\text { installa } \\
\text { Dollars } \\
\text { of lifet }\end{array}$ & $\begin{array}{l}\text { spent b } \\
\text { ts of } \mathrm{m} \\
\text { iso inc }\end{array}$ & $\begin{array}{l}U \text { include al } \\
\text { res for whic } \\
\text { estimated }\end{array}$ & $\begin{array}{l}\text { nstallatio } \\
\text { the WRA } \\
\text { ministrati }\end{array}$ & onc & 204 perce & 1 & oil, and pro & $\begin{array}{l}\text { une use } \\
\text { :" "bla }\end{array}$ & $s 85 \mathrm{pe}$ & $\begin{array}{l}t \text { of the } \\
\text { red. } \\
\text { estimates }\end{array}$ \\
\hline
\end{tabular}


A second method of analyzing cost effectiveness is to calculate the ratio of dollars saved by participants, over the life of the measures, by the cost of providing these measures. The resulting ratio indicates the customers' relative financial returns for participation in the program ${ }^{3}$. The higher the ratio, the greater the financial benefits to the participant per dollar of program costs.

General findings from this analysis (table 4-21) are similar to the results found for the analysis of WRAP dollars spent per MMBtu saved (see table 4-17 above). Plans E2 and E4 were the most beneficial, and while urban participants and owners benefitted more in 1989, in 1990 rural participants and renters received greater benefits. However, while the 1989 program was less cost effective among participants with primary electric space heat than among other participants, electric space heating participants received greater financial benefits from their participation than did others. This occurred because electricity is more expensive, on a $\$ / \mathrm{MMBtu}$ basis, than are gas or oil. In 1990, gas heating participants received greater financial benefits than did electric or oil heating participants, and the program was also more cost effective on a Btu basis for this group. The data indicates that the program saved more money in energy than it spent for every subgroup except for the electric space heating participants in plan E2. These participants yielded cost effectiveness ratios of less than 1.0.

3 There are many other benefits of program participation which are not included in this analysis, such as increased comfort and safety, arrearage reduction (see section 4-8), increased property values, and psychological benefits. 


\begin{tabular}{|c|c|c|c|c|c|c|c|c|c|c|}
\hline \multicolumn{11}{|c|}{$\begin{array}{c}\text { TABLE 4-21 } \\
\text { Dollars Saved by Participants per Dollar Spent by WRAP }\end{array}$} \\
\hline \multirow{2}{*}{ ron } & \multicolumn{5}{|c|}{$1080 \%+14$ prots } & \multicolumn{5}{|c|}{1000 rortapints. } \\
\hline & 40 & $0+14$ & $\mathrm{nu}$ & $10,1 \%$ & nonor & $10 \%$ & Hon & mort & $9 n+1$ & Renter \\
\hline E1 & 1.88 & 2.21 & 1.61 & 1.67 & 2.08 & 1.49 & 1.70 & 1.26 & 1.55 & 1.44 \\
\hline E2 & 6.09 & 9.42 & 2.13 & 7.13 & 2.50 & 3.61 & 3.74 & 3.37 & 3.65 & 3.55 \\
\hline E3 & 2.08 & 2.21 & 1.88 & 1.95 & 2.17 & 1.93 & 1.90 & 1.95 & 1.80 & 1.99 \\
\hline $\mathrm{E4}$ & 3.80 & 3.96 & 3.66 & 3.88 & 3.76 & 4.08 & 3.47 & 4.70 & 3.11 & 4.62 \\
\hline E5 & 2.35 & 2.34 & 2.36 & 2.30 & 2.42 & 2.74 & 2.49 & 3.10 & 2.58 & 2.99 \\
\hline Avg. & 3.00 & 3.64 & 2.37 & 3.35 & 2.62 & 3.10 & 2.81 & 3.44 & 2.72 & 3.44 \\
\hline \multirow{2}{*}{ P1\% } & \multirow{2}{*}{ 88: } & \multicolumn{4}{|c|}{ 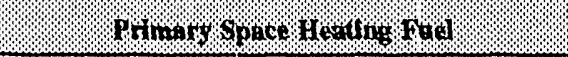 } & & \multicolumn{4}{|c|}{ 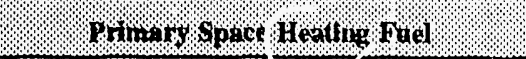 } \\
\hline & & Biourists & c.s. & out & 80170 & 898 & 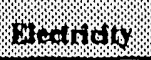 & 00 & 011 & Propane \\
\hline E1 & 1.88 & 7.38 & 1.37 & 1.48 & 2.43 & 1.49 & 5.19 & 1.10 & 1.55 & 4.87 \\
\hline $\mathrm{E} 2$ & 6.09 & 0.60 & 1.80 & 7.53 & N/A & 3.61 & 0.36 & 5.39 & 3.44 & 20.19 \\
\hline E3 & 2.08 & 5.58 & 1.75 & 1.76 & 3.13 & 1.93 & 3.84 & 1.40 & 1.69 & 3.27 \\
\hline E4 & 3.80 & 3.80 & 3.82 & 3.77 & 3.13 & 4.08 & 2.97 & 4.76 & 3.36 & 18,63 \\
\hline E5 & 2.35 & 3.78 & 2.78 & 2.09 & 8.77 & 2.74 & 2.90 & 3.78 & 2.51 & 19.58 \\
\hline Avg. & 3.00 & 5.16 & 2.55 & 3.35 & 7.06 & 3.10 & 3.55 & 4.00 & 2.69 & 16.11 \\
\hline $\begin{array}{l}\text { Note: } \\
\text { and } \$ 0\end{array}$ & $\begin{array}{l}\text { At savi } \\
\text { pane. }\end{array}$ & ere calcul & sing & llowir & & & ectricity, & ni & $\$ 0.90$ & $\begin{array}{l}\text { noil, } \\
\text { osts of }\end{array}$ \\
\hline
\end{tabular}




\subsection{ARREARAGE IMPACTS}

One of the primary objectives of the WRAP program is to assist low-income customers in reducing their utility debt. This section analyzes participants' electricity billing data in order to evaluate the success of the WRAP program in promoting electricity bill arrearage reductions.

Figure 4-2 graphically illustrates general payment and bill size patterns. The 1989 participant sample is used here as an example, but the general patterns apply to other WRAP participant groups as well. All variables shown on the graphs (monthly payment, monthly change in arrearage, and bill size) represent mean averages of the participant data. The data points used for analysis are the mean averages for monthly bill, monthly payment, and monthly change in arrearage for each participant in the dataset. Each "month" refers to a particular number of months before or after implementation of the plan, not to a calendar month. Thus, seasonal cycles can not be inferred from this graph. Later participants include those whose installation dates are more evenly distributed around the year, which minimizes the cyclical appearance.

The bill size line in figure 4-2 appears somewhat flat, indicating that variations have been canceled out in the averaging process. It can be surmised that any such variations were relatively insignificant, since only a small number of participants had electric heat. Thus, electricity consumption and bill size were driven primarily by non-weather-sensitive end-uses such as lighting and refrigeration. Monthly payments, however, show extreme irregularities that averaging did not conceal. The variations in payments indicate that payment size is not constant or driven solely by bill size, but that electricity payments are determined by exogenous influences, among which may be primary and secondary heating fuel bills. For example, customers with primary heating fuels other than electricity may make smaller electricity payments in the winter, when their heating fuel bills are larger. The mean average monthly change in the arrearage curve tracks bill payments inversely because of the flatness of the bill size curve.

Figure 4-3 shows data for participants with electric heat. In this graph, the average monthly bill curve is dramatically more irregular than for participants as a whole, due to the impact of weathersensitive heating electricity demand. The cyclical appearance in the curve is almost certainly caused by a seasonal influence in the data set; rather than being evenly distributed around the calendar year, the installations were grouped more heavily in certain months. One particularly important finding is that peaks in the bill payment curve seem to roughly track peaks in the bill size curve, but with a delay of one to three months. This pattern is consistent among graphs of different electric-heating participant subsets (see Appendix F). This may indicate that low-income customers do not anticipate unusually large monthly bills, and do not budget for them in advance, or that there is a delay of several months in the payment from energy assistance. In addition, the overall pattern of bill payments matches the bill size curve much more closely for electric heat participants than for participants as a whole. This supports the hypothesis that heating bills, irrespective of the fuel type, influence electricity bill payment size. If this hypothesis is true, than participation in WRAP should cause electricity payment patterns to improve, even among households heated by fuels other than electricity.

In order to assess quantitatively the effects of plan participation on the average monthly change in arrearage (AMCA), the AMCA for a full year after installation was compared to the AMCA for a full year before installation for both the 1989 and 1990 participants, when possible. Thus, seasonal effects in the data should be consistent for the two time periods of analysis. 


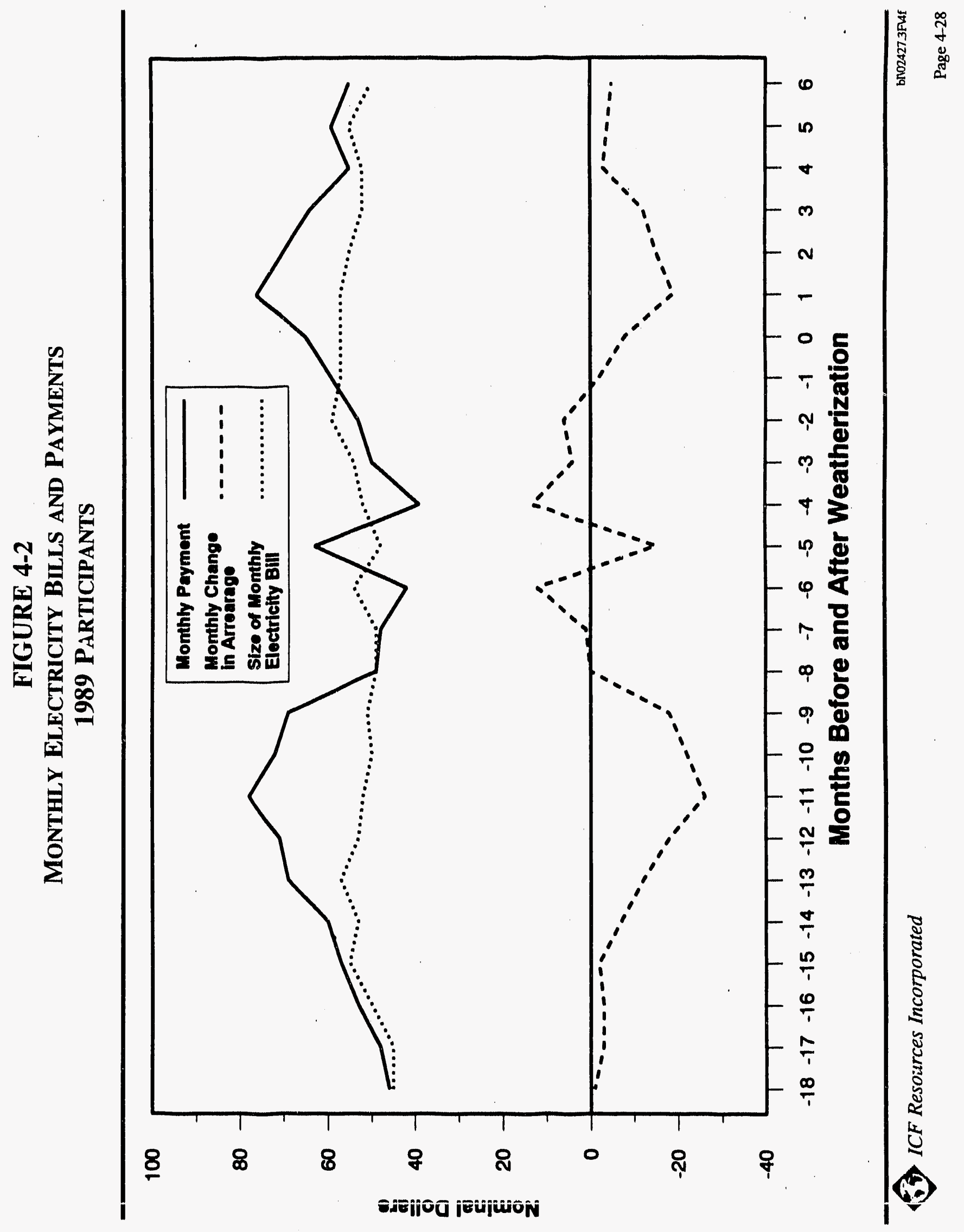




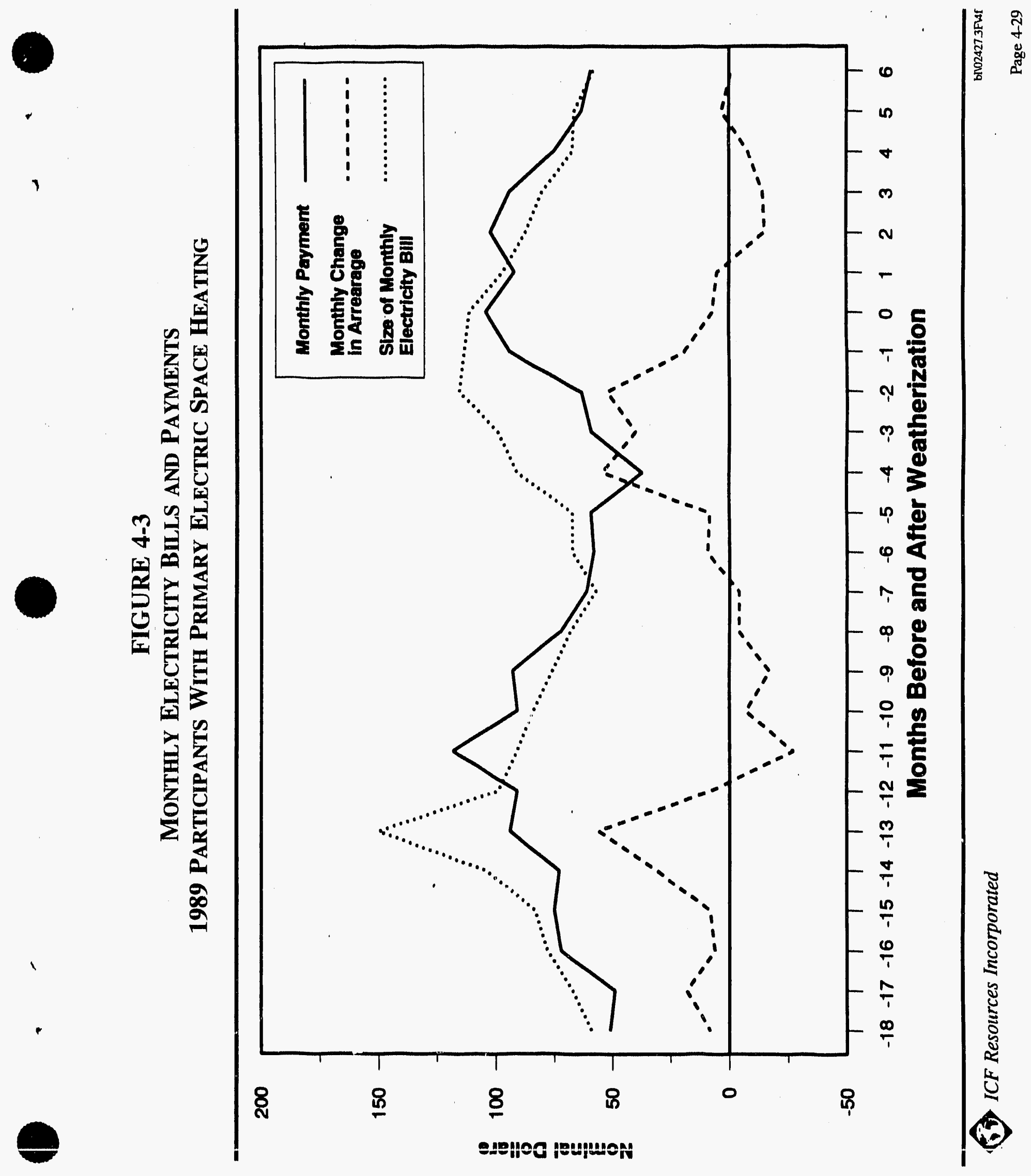


It is important to note that although the seasonal effect has essentially been controlled, the dataset has not been weather-adjusted. In other words, if the weather conditions during the year following installation were more severe for the average participant than the weather conditions of the same period a year earlier, the improvements in payment patterns may not be as great as they would have been if weather conditions had been comparable. However, it is felt that since the majority of the participants are not electrically heated and water-heated, any seasonal patterns are minor and not felt to warrant further analysis.

Similarly, there may be economic conditions such as wages, inflation and employment rates which also affect payments. The scope of this analysis does not include any quantification of these other factors.

Table 4-22 shows the difference, in real dollars, in the average monthly change in arrearage for the pre- and post-installation periods. A negative number represents an improvement in the debt payment pattern from Northeast Utilities' perspective: either the average amount being paid off each month increased, the average amount being added to the arrearage each month decreased, or the arrearage was increasing prior to installation and decreasing afterwards. A positive number indicates that changes in arrearages were worse in the sec ind period than in the first.

Overall, the data indicated an improvement in the average monthly change in arrearage of $\$ 9.73$ for the 1989 participant an $\$ \$ 18.77$ for 1990 . This improvement came mainly from urban participants, who showed an average improvement of $\$ 11.75$ for 1989 and $\$ 20.23$ for 1990 participants. Rural participants show an improvement in every plan for both years' participants. Rural participants showed a decrease in their AMCA of $\$ 7.60$ for 1989 and $\$ 16.07$ for 1990 .

\begin{tabular}{|c|c|c|c|}
\hline \multicolumn{4}{|c|}{$\begin{array}{c}\text { TABLE } 4-22 \\
\text { Change in Average Monthly Change in Arrearage } \\
1989 \text { and } 1990 \text { Participants }\end{array}$} \\
\hline Program l rear. & Trotal & Yrban. & gurral \\
\hline 1989 & $-\$ 9.73$ & $-\$ 11.75$ & $-\$ 7.60$ \\
\hline 1990 & -18.77 & -20.23 & -16.07 \\
\hline
\end{tabular}

Only plan E4 was specifically targeted to payment-troubled customers, with the express purpose of reducing arrearages. As tables 4-23 and 4-24 show, plan E4 was highly successful in this regard. The average improvement in arrearages among plan E4 participants was approximately $\$ 40.00$ for 1989 and $\$ 28.00$ for 1990 . The only subset showing a worsening of arrearage payment patterns was participants with oil heat for 1989 and propane heat in 1990 (see table 4-25). They increased their AMCA by $\$ 0.72$ for 1989 and $\$ 3.00$ for 1990 . However, the sample sizes of these subsets are small, so these results may be due to statistical outliers. 


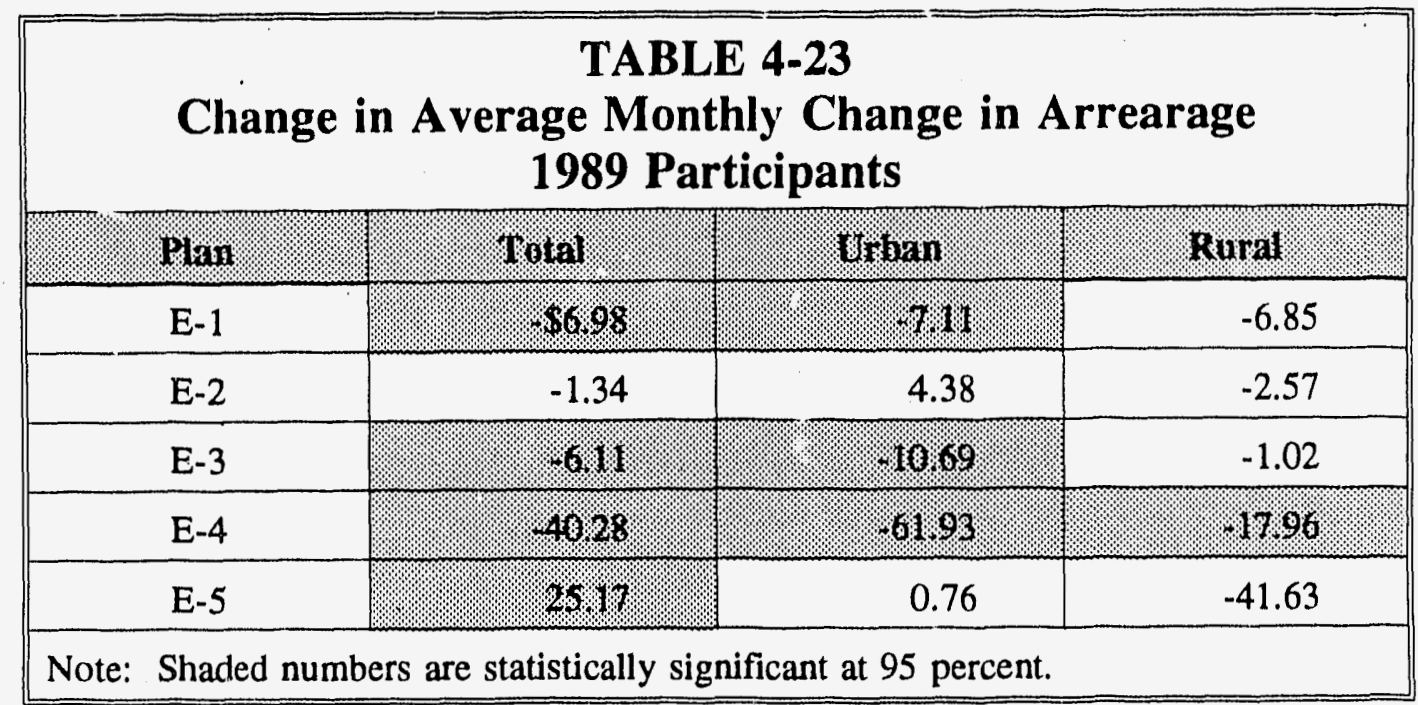

\begin{tabular}{|c|c|c|c|}
\hline \multicolumn{4}{|c|}{$\begin{array}{l}\text { TABLE 4-24 } \\
\text { Change in Average Monthly Change in Arrearage } \\
1990 \text { Participants }\end{array}$} \\
\hline Tian. & 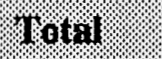 & Urban. & rerral. \\
\hline E-1 & 816.63. & 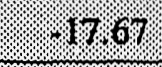 & .14 .88 \\
\hline E-2 & $17.16 \%$ & $18.9 \% 8$ & -12.88 \\
\hline E-3 & 8.1824 & .19 .84 & -15.06 \\
\hline E-4 & 28.80 & $4: 2,28$ & 21,02 \\
\hline E-5 & $14: 3$. & 18.96 & -14.43 \\
\hline
\end{tabular}




\begin{tabular}{|c|c|c|}
\hline \multicolumn{3}{|c|}{$\begin{array}{c}\text { TABLE 4-25 } \\
\text { Change in Average Monthly Change in } \\
\text { Arrearage } \\
\text { By Primary Fuel Types }\end{array}$} \\
\hline Rrmary thal tres & 1989 & 1990 \\
\hline Electricity & -31293 & 21.73 \\
\hline Gas & 21.98 & 22.17 \\
\hline Oil & 0.72 & 21527 \\
\hline Propane & -2.60 & 3.01 \\
\hline Other & -12.22 & -4.90 \\
\hline
\end{tabular}

For all the participants and for all fuel types, the arreirage reduction is found to bc from $\$ 10$ to $\$ 20$ after one year of installed WRAP measures (table 4-25). It was found that the electric and gas heated participants in 1989 achieved a statistically significant reduction in their arrearages (99 percent). The same was found for the 1990 participants; oil heated participants were also found to statistically significantly reduce their arrearages as well (electric at 95 percent, gas and oil at 99 percent).

In summary, it was found that after reviewing payment data for one year pre-installation and one full year post-installation, the WRAP program reduced participants' arrearages, and many did so in a statistically significant manner. Thus, for the objective of reduced arrearage, the program has been very successful in the short term (one year). Other comparisons of arrearage reduction are shown for the 1989 and 1990 participants in Appendix F. 


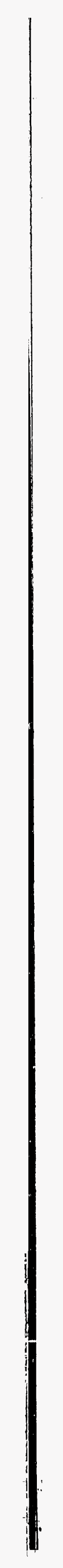

